\title{
Influence of future air pollution mitigation strategies on total aerosol radiative forcing
}

\author{
S. Kloster ${ }^{1,{ }^{*}}$, F. Dentener ${ }^{1}$, J. Feichter ${ }^{2}$, F. Raes ${ }^{1}$, J. van Aardenne ${ }^{1}$, E. Roeckner ${ }^{2}$, U. Lohmann ${ }^{3}$, P. Stier ${ }^{4}$, and \\ R. Swart ${ }^{5}$ \\ ${ }^{1}$ European Commission, Institute for Environment and Sustainability, Ispra (VA), Italy \\ ${ }^{2}$ Max Planck Institute for Meteorology, Hamburg, Germany \\ ${ }^{3}$ Institute of Atmospheric and Climate Science, ETH Zuerich, Switzerland \\ ${ }^{4}$ University of Oxford, Atmospheric, Oceanic and Planetary Physics, Oxford, UK \\ ${ }^{5}$ EEA European Topic Centre on Air and Climate Change (ETC/ACC), MNP, Bilthoven, The Netherlands \\ *now at: Cornell University, Ithaca, NY, USA
}

Received: 18 January 2008 - Published in Atmos. Chem. Phys. Discuss.: 18 March 2008

Revised: 1 September 2008 - Accepted: 1 September 2008 - Published: 11 November 2008

\begin{abstract}
We apply different aerosol and aerosol precursor emission scenarios reflecting possible future control strategies for air pollution in the ECHAM5-HAM model, and simulate the resulting effect on the Earth's radiation budget. We use two opposing future mitigation strategies for the year 2030: one in which emission reduction legislation decided in countries throughout the world are effectively implemented (current legislation; CLE 2030) and one in which all technical options for emission reductions are being implemented independent of their cost (maximum feasible reduction; MFR 2030).

We consider the direct, semi-direct and indirect radiative effects of aerosols. The total anthropogenic aerosol radiative forcing defined as the difference in the top-of-theatmosphere radiation between 2000 and pre-industrial times amounts to $-2.00 \mathrm{~W} / \mathrm{m}^{2}$. In the future this negative global annual mean aerosol radiative forcing will only slightly change $\left(+0.02 \mathrm{~W} / \mathrm{m}^{2}\right)$ under the "current legislation" scenario. Regionally, the effects are much larger: e.g. over Eastern Europe radiative forcing would increase by $+1.50 \mathrm{~W} / \mathrm{m}^{2}$ because of successful aerosol reduction policies, whereas over South Asia it would decrease by $-1.10 \mathrm{~W} / \mathrm{m}^{2}$ because of further growth of emissions. A "maximum feasible reduction" of aerosols and their precursors would lead to an increase of the global annual mean aerosol radiative forcing by $+1.13 \mathrm{~W} / \mathrm{m}^{2}$. Hence, in the latter case, the present day negative anthropogenic aerosol forcing could be more than halved by 2030 because of aerosol reduction policies and climate
\end{abstract}

Correspondence to: F. Dentener (frank.dentener@jrc.it) change thereafter will be to a larger extent be controlled by greenhouse gas emissions.

We combined these two opposing future mitigation strategies for a number of experiments focusing on different sectors and regions. In addition, we performed sensitivity studies to estimate the importance of future changes in oxidant concentrations and the importance of the aerosol microphysical coupling within the range of expected future changes. For changes in oxidant concentrations caused by future air pollution mitigation, we do not find a significant effect for the global annual mean radiative aerosol forcing. In the extreme case of only abating $\mathrm{SO}_{2}$ or carbonaceous emissions to a maximum feasible extent, we find deviations from additivity for the radiative forcing over anthropogenic source regions up to $10 \%$ compared to an experiment abating both at the same time.

\section{Introduction}

Anthropogenic aerosol causes a variety of adverse health effects, resulting in increased mortality and hospital admissions for cardiovascular and respiratory diseases (WHO, 2003). As a consequence, in the last decades legislation was introduced in Western Europe and North America to reduce aerosol and aerosol precursor emissions to improve air quality. For instance, in Europe $\mathrm{SO}_{2}$ emissions decreased by $\sim 73 \%$ between 1980 and 2004 (Vestreng et al., 2007), and in the USA by $\sim 37 \%$ between 1970 and 1996 (EPA, 2000). Also in developing countries, facing increasing urbanization, mobilization and industrialization, air pollution has become a major concern. Therefore, in recent years

Published by Copernicus Publications on behalf of the European Geosciences Union. 
legislation has been introduced by governments worldwide to reduce aerosol and aerosol precursor emissions and improve air quality (Andreae, 2007; Cofala et al., 2007).

These future changes in anthropogenic aerosol and aerosol precursor emissions can exert a wide range of climate effects. A comprehensive understanding of the aerosol climate effects arising from multiple aerosol compounds and various mechanisms is essential for an understanding of past and present-day climate, as well as for future climate change.

Aerosols affect climate directly by scattering and absorption of radiation (direct aerosol effect; Ångstroem, 1962). The absorption of radiation by aerosols leads to temperature changes in the atmosphere and subsequent evaporation of cloud droplets (semi-direct effect; Hansen et al., 1997). They also affect climate indirectly by modulating cloud properties. Aerosols enhance the cloud albedo due to the formation of more and smaller cloud droplets (cloud albedo effect; Twomey, 1977) and aerosols potentially prolong the lifetime of clouds because smaller droplets form less likely precipitation (cloud lifetime effect; Albrecht, 1989). Most estimates of the direct and indirect effects on the Earth's radiation balance have been obtained from global model simulations, but estimates at present vary greatly (Forster et al., 2007).

Several studies investigated the impact of changes in air pollution and associated impacts on radiation and climate applying anthropogenic emission forecast from the Intergovernmental Panel on Climate Change (IPCC) Special Report on Emission Scenarios (SRES) (Nakicenovic et al., 2000) using global climate models with varying degrees in complexity (Unger et al., 2008, Menon et al., 2008, Shindell et al., 2007, Shindell et al., 2008, Koch et al., 2007b). This study evaluates the impact of two recent sector-wise air pollution emission scenarios for the year 2030 provided by IIASA (International Institute for Applied System Analysis, Cofala et al., 2007) on the radiation balance of the Earth. The two scenarios are the "current legislation" (CLE) scenario reflecting the implementation of existing emission control legislation, and the alternative "maximum feasible reduction" (MFR) scenario, which assumes that the most advanced emission control technologies presently available will be implemented worldwide. These scenarios are input to the stateof-the art ECHAM5-HAM Atmospheric General Circulation model extended by an aerosol-cloud microphysical model (Roeckner et al., 2003; Stier et al., 2005; Lohmann et al., 2007) to evaluate their impact on the radiation budget of the atmosphere using the radiative forcing (RF) concept. Here we focus on the year 2030, the policy relevant future, and contrast future changes with present day anthropogenic RF, defined as the difference between and present-day and preindustrial (PI) times.

Air pollution legislations target mainly specific emission sectors, e.g. power generation, traffic. Climate assessments of aerosol impacts, typically focused on specific aerosol components, e.g. the RF by $\mathrm{SO}_{4}$ or BC (IPCC, 2001; Forster et al., 2007; Reddy et al., 2005; Takemura et al., 2002). To inform policy, it would be most useful to evaluate the effect on climate of sectoral air pollution mitigation. A complicating factor of this approach is that air pollutants interact in the atmosphere in a non-linear way. For example, couplings exist between sulfate formation and tropospheric chemistry (Roelofs et al., 1998; Unger et al., 2006). Also, aerosol lifecycles are not independent. Aerosol mass and number respond in a non-linear way to changes in aerosol and aerosol precursor emissions (Stier et al., 2006a) and thus lead to a non-linear response in the associated climate effects. Moreover, aerosols and climate are coupled through the hydrological cycle (Feichter et al., 2004).

Here we evaluate the importance of the combined industrial and power generation sector on the one hand, and domestic and transport related emission on the other hand. In addition, we conducted regional experiments to evaluate the influence aerosol emissions from Europe and Asia have on other world regions. A number of sensitivity studies address the non-linear chemical and microphysical couplings in the context of these scenarios.

The paper is organized as follows: In Sect. 2 the model setup is described. In Sect. 3 the simulation setup for the single experiments is outlined. The results are presented in Sect. 4. The additional sensitivity experiments are discussed in Sect. 5. Finally, the results are discussed and concluding remarks are presented in Sect. 6.

\section{Model setup}

In this study we use the atmospheric general circulation model ECHAM5 (Roeckner et al., 2003) extended by the microphysical aerosol model HAM (Stier et al., 2005) and a cloud scheme with a prognostic treatment of cloud droplet and ice crystal number concentration (Lohmann et al., 2007). In the following sections, we briefly describe the model components.

\subsection{The atmospheric model ECHAM5}

We applied the atmospheric general circulation model ECHAM5 (Roeckner et al., 2003) with a vertical resolution of 31 levels on hybrid sigma-pressure coordinates up to the pressure level of $10 \mathrm{hPa}$ and a horizontal resolution of T63 (about $1.8^{\circ} \times 1.8^{\circ}$ on a Gaussian Grid). Prognostic variables of ECHAM5 are vorticity, divergence, surface pressure, temperature, water vapor, cloud liquid water and cloud ice. A flux form semi-Lagrangian transport scheme (Lin and Rood, 1996) advects water vapor, cloud liquid water, cloud ice and tracer components. Cumulus convection is based on the mass flux scheme after Tiedtke (1989) with modifications according to Nordeng (1994). Cloud cover is predicted according to Sundquist et al. (1989) diagnosing the fractional cloud cover from relative humidity. The shortwave radiation scheme is adapted from the latest version of the 
ECMWF model including 6 bands in the visible and ultraviolet (Cagnazzo et al., 2007). The transfer of longwave radiation is parameterized after Morcrette et al. (1998).

\subsection{The aerosol model HAM}

Within ECHAM5 the microphysical aerosol module HAM (Stier et al., 2005) predicts the evolution of an ensemble of interacting internally - and externally - mixed aerosol modes. The main components of HAM are the microphysical core M7 (Vignati et al., 2004), an emission module, a sulfur oxidation chemistry scheme using prescribed oxidant concentrations for $\mathrm{OH}, \mathrm{NO}_{2}, \mathrm{O}_{3}$ and $\mathrm{H}_{2} \mathrm{O}_{2}$ (Feichter et al., 1996), a deposition module, and a module defining the aerosol radiative properties. The aerosol spectrum is represented by a superposition of seven log-normal modes. The seven modes are divided into four geometrical size classes (nucleation, Aitken, accumulation and coarse mode). Three of the modes include only hydrophobic compounds, four of the modes contain at least one hydrophilic compound. In the current setup the major global aerosol compounds sulfate (SU), black carbon (BC), particulate organic mass (POM), sea salt (SSA), and mineral dust (DU) are included.

M7 considers coagulation among the aerosol modes, condensation of gas-phase sulfuric acid onto the aerosol surface, the formation of new particles by binary nucleation of sulfate, and the water uptake depending on the thermodynamic equilibrium with ambient humidity (Vignati et al., 2004). Particles in the hydrophobic modes are transformed to the corresponding hydrophilic/mixed mode by condensation of sulfate on the surface or by coagulation with particles of the hydrophilic modes. The total condensable sulfate and the sulfate added by coagulation are attributed to the number of particles that can be coated with a minimal layer of sulfate in the respective mode. As minimal layer thickness a mono-layer is assumed. Within HAM deposition processes (dry deposition, wet deposition and sedimentation) are parameterized in dependence of aerosol size and composition.

The emissions of mineral dust and sea salt are calculated interactively (Tegen et al., 2002 and Schulz et al., 2004, respectively). Oceanic DMS emissions are calculated from the prescribed monthly mean DMS sea surface concentration (Kettle and Andreae, 2000) and a piston velocity calculated according to Nightingale et al. (2000). The prognostic treatment of the aerosol size distribution, mixing state, and composition allows the explicit simulation of the aerosol optical properties within the framework of the Mie theory. The optical properties are pre-calculated and supplied in a look-up table, providing the necessary input for the radiation scheme in ECHAM5.

\subsection{Aerosol cloud coupling}

The standard ECHAM5 cloud scheme which treats cloud water and ice water mixing ratios as prognostic quantities has recently been extended by prognostic equations for the cloud droplet number concentration (CDNC) and ice crystal number concentrations (Lohmann et al., 2007). Nucleation of cloud droplets is parameterized semi-empirically in terms of the aerosol number size distribution and vertical velocity (Lin and Leaitch, 1997). Sub-grid scale vertical velocity is derived from the turbulent kinetic energy (Lohmann et al., 1999). The cloud optical properties depend on the droplet effective radius, which is a function of the in-cloud liquid water content and CDNC. CDNC affects also the auto-conversion rate which is parameterized according to Khairoutdinov and Kogan (2000). Thus, this setup allows simulation of both the cloud-albedo and cloud-lifetime indirect aerosol effects.

\subsection{Model evaluation}

A detailed comparison of the simulated aerosol mass and number concentrations in ECHAM5-HAM with measurements is given in Stier et al. (2005). Radiation and water budgets as simulated with ECHAM5-HAM extended by the aerosol-cloud coupling scheme are compared to observations in Lohmann et al. (2007). It is beyond the scope of this study to repeat a full evaluation of model performance. Nevertheless, since this study includes a different emission inventory and uses different offline oxidant concentration fields we compared the simulated aerosol surface concentrations for $\mathrm{SO}_{4}, \mathrm{BC}$ and $\mathrm{POM}$ with observations from the EMEP (http:www.emep.int) and the IMPROVE (http:// vista.cira.colostate.edu/improve/) network for the year 2000, as done in Stier et al. (2005). Note here, that previous model studies used AeroCom aerosol and aerosol precursor emissions in combination with offline oxidant concentrations as predicted within the MOZART chemistry model (Horowitz et al., 2003), whereas this study uses IIASA aerosol and aerosol precursor emissions in combination with offline oxidant concentrations as predicted within the TM3 chemistry model (Dentener et al., 2005) (see also Table 1 and Sect. 3.2).

The comparison of simulated versus measured surface concentrations of this study are shown in Fig. A1a-c in the appendix. As reference, Fig. A1d-f in the appendix shows the same comparison as published in Stier et al. (2005). The simulated $\mathrm{SO}_{4}$ mass was slightly overestimated over Europe within the ECHAM5-HAM reference simulation (Stier et al., 2005). In this study we achieve a better agreement as $\mathrm{SO}_{4}$ surface concentrations are simulated lower over $\mathrm{Eu}-$ rope. Lower surface concentrations here are caused by different partly compensating effects: (i) $\mathrm{SO}_{2}$ emissions differ in terms of International Shipping emissions between AeroCom and this study (AeroCom uses EDGAR3.2 (Olivier et al., 2002) for 1995 plus a $1.5 \%$ increase until 2000 and this study applied Eyring et al., 2005). Overall the ship emissions are higher in this study and consequently lead to an increase of $\mathrm{SO}_{4}$ surface concentrations $(+2 \%$ for the global annual mean) (ii) the inclusion of the aerosol-cloud coupling in our study increases the $\mathrm{SO}_{4}$ lifetime (4.4 d compared to 
Table 1. Pre-industrial, present and future aerosol and aerosol precursor emissions as given in the IIASA and AEROCOM inventory (Cofala et al., 2007; Dentener et al., 2006a) and emissions used in the base simulations (2000,PI,MFR:2030,CLE:2030. Units are Tg(S)/yr for SO 2 emissions and $\mathrm{Tg} / \mathrm{yr}$ for BC and POM.

\begin{tabular}{|c|c|c|c|c|c|c|c|c|c|c|c|c|}
\hline & \multicolumn{3}{|c|}{1750} & \multicolumn{3}{|c|}{2000} & \multicolumn{3}{|c|}{ CLE 2030} & \multicolumn{3}{|c|}{ MFR 2030} \\
\hline & $\mathrm{BC}$ & POM & $\mathrm{SO}_{2}$ & $\mathrm{BC}$ & POM & $\mathrm{SO}_{2}$ & $\mathrm{BC}$ & POM & $\mathrm{SO}_{2}$ & $\mathrm{BC}$ & POM & $\mathrm{SO}_{2}$ \\
\hline Road-Transport & & & & 0.70 & 0.98 & 0.96 & 0.52 & 0.94 & 1.2 & 0.17 & 0.50 & 0.45 \\
\hline Non-Road Transport & & & & 0.53 & 0.54 & 0.76 & 0.50 & 0.48 & 1.0 & 0.06 & 0.04 & 0.18 \\
\hline International Shipping $^{\mathrm{a}}$ & & & & 0.05 & 0.13 & 5.85 & 0.08 & 0.23 & 8.9 & 0.07 & 0.18 & 3.12 \\
\hline Powerplants & & & & 0.04 & 0.05 & 24.2 & 0.05 & 0.08 & 20.9 & 0.06 & 0.01 & 1.80 \\
\hline Industry & & & & 0.42 & 0.63 & 19.6 & 0.37 & 0.45 & 24.3 & 0.004 & 0.01 & 5.75 \\
\hline Domestic & & & & 3.34 & 13.15 & 5.87 & 2.65 & 7.61 & 4.0 & 2.52 & 5.90 & 2.20 \\
\hline Total anthropogenic IIASA & & & & 5.08 & 15.48 & 57.24 & 4.17 & 9.79 & 60.3 & 2.88 & 6.64 & 13.5 \\
\hline Vegetation fires ${ }^{\mathrm{b}}$ & 1.0 & 12.8 & 0.7 & 3.1 & 34.7 & 2.1 & 3.1 & 34.7 & 2.1 & 3.1 & 34.7 & 2.1 \\
\hline Natural $^{\mathrm{b}}$ & - & 19.1 & 14.6 & - & 19.1 & 14.6 & - & 19.1 & 14.8 & - & 19.1 & 14.8 \\
\hline Total anthropogenic AEROCOM & 0.39 & 1.56 & 0.06 & & & & & & & & & \\
\hline PI & 1.39 & 33.46 & 15.36 & & & & & & & & & \\
\hline 2000 & & & & 8.18 & 69.28 & 73.94 & & & & & & \\
\hline CLE:2030 & & & & & & & 7.27 & 63.59 & 77.2 & & & \\
\hline MFR:2030 & & & & & & & & & & 5.98 & 60.44 & 30.4 \\
\hline
\end{tabular}

a International Shipping emissions are from Eyring et al. (2005);

$\mathrm{b}$ Vegetation fire and Natural Emissions are from AEROCOM (Dentener et al. (2006a) and references therein). They are assumed to be constant in the future.

$4.0 \mathrm{~d})$. Such an increase in lifetime caused by aerosol-cloud coupling is governed by decreasing precipitation formation in the presence of high sulfate concentrations (Lohmann and Feichter, 1997). Consequently, the longer lifetime leads to higher $\mathrm{SO}_{4}$ surface concentrations. (iii) $\mathrm{OH}$ concentrations as simulated with TM3 are lower than the MOZART concentrations (see also appendix Table A2) leading to a lower gas-phase production of $\mathrm{SO}_{4}$ and subsequently to lower $\mathrm{SO}_{4}$ concentrations (the global annual mean decreases by $-13 \%$ ). Overall, this explains the differences in the $\mathrm{SO}_{4}$ surface concentrations between the ECHAM5-HAM reference simulation as given in Stier et al. (2005) and this study.

While the comparison with BC and POM surface concentration measurements over North America shows in general a good agreement for the ECHAM-HAM5 reference simulation, the surface concentrations in our study tend to underestimate the observed values (most pronounced for BC). The simulated lifetimes for BC and POM are almost identical in both studies. The differences are solely caused by the different emission inventories. Stier et al. (2005) applied the Bond et al. (2004) inventory for anthropogenic BC and POM emissions which are higher over North America compared to the IIASA inventory ( $23 \%$ for BC and $7 \%$ for POM emissions). Therefore, the $\mathrm{BC}$ as well as the $\mathrm{OC}$ response towards future changes is likely to be a lower estimate in the current study.
Overall the ECHAM5-HAM version used in this study shows reasonable good agreement with observations, a prerequisite to explore the effects of various aerosol future emission scenarios.

\section{Simulation setup}

We performed a series of experiments applying different future aerosol and aerosol precursor emission scenarios to investigate the associated aerosol radiative effects. In all these experiments the large-scale meteorology is constrained to the year 2000, nudging the ECHAM5-HAM simulated temperature, $\log$ surface pressure, vorticity and divergence to the ECMWF ERA40 reanalysis data (Uppala et al., 2005). With the nudging technique the large-scale meteorology is constrained, whereas smaller scale processes, such as cloud formation, respond to perturbations induced into the system (Jeuken et al., 1996). Thus, aerosol effects on the meteorological state are small. The nudging technique allows to a large extent compliance with the definition of the adjusted radiative forcing (RF) as given by Forster et al. (2007), which is defined as the change in net (down minus up) irradiance at the tropopause after the introduction of a perturbation with surface and tropospheric temperatures and state of meteorology held fixed at the unperturbed values, while allowing the stratosphere to adjust. The difference is that in the set-up applied in this study: (i) temperature and state are held fixed for 
the entire atmosphere which equals instantaneous RF according to Forster et al. (2007). For most tropospheric aerosol forcing stratospheric adjustment has little effect on the RF, and the instantaneous RF at the top of the atmosphere (TOA) equals the adjusted RF; (ii) aerosol-cloud feedback mechanisms are enabled. All experiments presented here were conducted for one year with a spin-up of three months.

\subsection{Aerosol emissions}

Aerosol emissions were provided by IIASA using the global version of the Regional Air Pollution Information and Simulation (RAINS) model (Dentener et al., 2005, and updates described in Cofala et al., 2007). The RAINS model provides two future scenarios: "current legislation" (CLE) and "maximum feasible reduction" (MFR) up to the year 2030.

CLE reflects current perspectives of economic development and takes into account presently decided control legislations for future developments assuming full compliance. MFR assumes a full implementation of today's most advanced technologies worldwide. Non-technical structural measures, e.g. fuel shifts, are not considered. Both scenarios use the same underlying activity level projection, which is based on current national perspectives on the sectoral economic and energy development up to the year 2030 in regions where data is available. For the other world regions the trends of future economic and energy developments of the IPCC SRES B2 MESSAGE scenario (Riahi and Roehl, 2005; Nakicenovic et al., 2000) are applied.

RAINS considers the aerosol and aerosol precursor emissions of $\mathrm{SO}_{2}, \mathrm{BC}$ and $\mathrm{OC}$ for the emission sectors: Road Transport, Non-Road Transport, Industry, Powerplants, and Domestic Use. These emissions are all given as national estimates. Following (Dentener et al., 2005) we gridded these by utilizing the 1995 gridded sectoral distribution of the EDGAR3.2 global emission inventory (Olivier and Berdowski, 2001) on a $1^{\circ} \times 1^{\circ}$ Gaussian grid. For the conversion of the carbon mass of $\mathrm{OC}$ into the total mass of POM needed in ECHAM5-HAM a factor of 1.4 was applied. Emissions from international shipping and aviation were not included in the IIASA emission inventory. We added international shipping emissions from a different inventory (Eyring et al., 2005). For MFR we choose the technology scenario TS1 ("CLEAN"), for CLE the technology scenario TS4 ("Business-as-Usual"), both with an underlying GDP growth of 3.1\%/yr which is close to the GDP growth of the SRES B2 scenario $(2.8 \% / \mathrm{yr})$.

For this study we focus our analysis on the year 2030 in comparison to present-day conditions (2000) and contrast the results with present day anthropogenic RF, defined as the difference between 2000 and pre-industrial (PI) times. In the following we will denote the two different IIASA scenarios as CLE 2030 and MFR 2030, respectively.

Open biomass burning and natural aerosol emissions are taken from the AeroCom emission inventories (Dentener et al., 2006a and references therein) for the present-day (2000) and pre-industrial (PI) experiments. Future changes are not taken into account, i.e., all future experiments (2030) use the emissions representative for the year 2000. However, BC and POM emissions from biomass burning emissions are likely to change. According to Streets et al. (2004) $\mathrm{BC}$ and $\mathrm{POM}$ emissions from open biomass burning emissions will decrease by 2030 , ranging from $-9 \%$ and $-11 \%$ for BC and POM in a SRES A1B scenario and up to $-24 \%$ and $-22 \%$ in a SRES B2 scenario compared to the year 1996 (BC: $3.2 \mathrm{Tg} / \mathrm{yr}$, POM: $35.6 \mathrm{Tg} / \mathrm{yr}$ ). However, given the large uncertainties related to open biomass burning emissions at present as well as in their future development we felt that it was justified in a first approach to keep them constant. In addition, this study concerns the impact of current legislation and technical measures to reduce air pollution. Clearly these measures do no apply to open biomass burning.

The emissions are detailed for the different sectors in Table 1. The evolution of the aerosol emissions for the different experiments are discussed together with the resulting changes in the aerosol burden in Sect. 4.1.

\subsection{Oxidant concentrations}

The main coupling of photochemistry and aerosol is through the chemistry of DMS and $\mathrm{SO}_{2}$. ECHAM5-HAM assumes that DMS is completely oxidized in the gas-phase by $\mathrm{OH}$ and $\mathrm{NO}_{3}$ radicals to form $\mathrm{SO}_{2}$ and $\mathrm{SO}_{4} . \mathrm{SO}_{2}$ is oxidized in the gas-phase, and can also react in clouds (aqueous phase) with $\mathrm{H}_{2} \mathrm{O}_{2}$ and $\mathrm{O}_{3}$ (Feichter et al., 1996). For computational efficiency ECHAM5-HAM uses offline chemistry fields in its standard version. They were taken from an earlier study with the offline chemistry model TM3 model (Dentener et al. (2003) and references therein). That study was performed using the same CLE and MFR scenarios as utilized here, including a coupled photo-oxidant- $\mathrm{SO}_{4}$ chemistry (Dentener et al., 2005). However, uncertainties arise from the fact that this was a different model using different meteorological driving fields so that the oxidant fields are not fully consistent with the present study. In addition, prescribing $\mathrm{H}_{2} \mathrm{O}_{2}$ concentrations might underestimate the resulting sulfate burden as $\mathrm{H}_{2} \mathrm{O}_{2}$ is actually strongly depleted in anthropogenic source regions by aqueous reaction with $\mathrm{SO}_{2}$. This will increase the gas-phase production of $\mathrm{SO}_{4}$ which is less susceptible to scavenging and increase the $\mathrm{SO}_{4}$ burden (Barth et al. , 2000; Roelofs et al., 1998).

\subsection{Description of the single experiments}

In the following section we briefly summarize the experiments performed within this study (Table 2).

We performed a present-day, pre-industrial and two future experiments in which the $\mathrm{SO}_{2}, \mathrm{BC}$, and $\mathrm{POM}$ emissions are prescribed using the 2000, pre-industrial and MFR 2030 and CLE 2030 estimates (2000, PI, MFR:2030, CLE:2030). We 
Table 2. Overview of the different experiments conducted in this study. IIASA 2000 aerosol emissions refer to aerosol and aerosol precursor emission ( $\mathrm{SO}_{2}, \mathrm{BC}$ and POM) inventory provided by the Institute for Applied System Analysis (IIASA) representative for the year 2000; IIASA MFR 2030 refers to aerosol emissions for the year 2030 assuming that "maximum feasible reduction" will be applied in the future to reduce aerosol and aerosol precursor emissions; IIASA CLE 2030 refers to aerosol emissions for the year 2030 assuming that "current legislation" will be applied in the future. AEROCOM 1750 refers to aerosol emissions representative for pre-industrial times as given in the Aerosol Model Inter-Comparison project (http://nansen.ipsl.jussieu.fr/AEROCOM, Dentener et al., 2006a). Oxidant concentrations $\left(\mathrm{H}_{2} \mathrm{O}_{2}\right.$, $\mathrm{OH}, \mathrm{O}_{3}, \mathrm{NO}_{2}$ ) are taken from an offline chemistry TM3 model study using ozone precursor emissions for the future from the IIASA scenario consistent with the aerosol emissions (Dentener et al., 2005).

\begin{tabular}{lll}
\hline Experiment & Aerosol emissions & Oxidant concentrations \\
\hline 2000 & IIASA 2000 & 2000 \\
PI & AEROCOM 1750/pre-industrial & 2000 \\
MFR:2030 & IIASA MFR 2030 & MFR 2030 \\
CLE:2030 & IIASA CLE 2030 & CLE 2030 \\
MFR:2030:IP & $\begin{array}{l}\text { Industry/Powerplants sector : IIASA MFR 2030 } \\
\text { Domestic/Transport sector : IIASA CLE 2030 }\end{array}$ & 2000 \\
MFR:2030:DT & $\begin{array}{l}\text { Industry/Powerplants sector : IIASA CLE 2030 } \\
\text { Domestic/Transport sector : IIASA MFR 2030 }\end{array}$ & 2000 \\
MFR:2030:EUROPE & $\begin{array}{l}\text { Europe : IIASA MFR 2030 } \\
\text { World-Europe : IIASA CLE 2030 }\end{array}$ & 2000 \\
MFR:2030:ASIA & $\begin{array}{l}\text { Asia : IIASA MFR 2030 } \\
\text { World-Asia : IIASA CLE 2030 }\end{array}$ & 2000 \\
MFR:2030:CHEM:2000 & IIASA MFR 2030 & 2000 \\
CLE:2030:CHEM:2000 & IIASA CLE 2030 & 2000 \\
2000:CHEM:2030:MFR & IIASA 2000 & MFR 2030 \\
SULFATE:2000 & Sulfate : IIASA 2000 & MFR 2030 \\
BC/POM : IIASA MFR 2030 & MFR 2030 \\
CARBON:2000 & $\begin{array}{l}\text { Sulfate : IIASA MFR 2030 } \\
\text { BC/POM : IIASA 2000 }\end{array}$ \\
\hline
\end{tabular}

further performed two "sectoral reduction" experiments: one in which the aerosol emissions from the Industry and Powerplant sector are reduced according to the MFR 2030 scenario and the other sectors (Domestic and Transport) follow CLE 2030 (MFR:2030:IP) and a similar simulation for the Domestic and Transport sector (MFR:2030:DT). To demonstrate to what extent emission reduction of specific regions could impact the region itself but also other regions due to aerosol export we also conducted two "regional reduction" experiments: one in which it is assumed that the aerosol emissions in Europe will be reduced according to the MFR 2030 scenario, and the rest of the world follows the CLE 2030 scenario (MFR:2030:EUROPE) and a similar simulation for Asia (MFR:2030:ASIA). The regions defined as Europe and Asia are shown in Fig. A4 in the appendix.

As explained in Sect. 3.2., we use prescribed off-line oxidant concentrations from prior TM3 simulations (Dentener et al., 2005), which applied the IIASA emission inventory for 2000, MFR 2030 and CLE 2030. In the case of the 2000 and PI experiment the 2000 oxidant concentrations are taken, for the MFR:2030 and CLE:2030 scenario the respective TM3 scenario calculations are used. To limit the amount of degrees of freedom we used for both the "sectoral reduction" and "regional reduction" experiments the TM3 2000 calculations, and devote separate sensitivity experiments to the evaluation of the impact of different oxidant fields.

In order to test the effect of changes in the oxidant concentrations on the $\mathrm{SO}_{4}$ formation and subsequently on the aerosol lifecycles and RF we performed three additional experiments: two in which the aerosol emissions for MFR 2030 and CLE 2030 are used in combination with the offline oxidant concentrations for the year 2000 (MFR:2030:CHEM:2000, CLE:2030:CHEM:2000) and one in which the aerosol emissions for the year 2000 are applied in combination with the offline oxidant concentrations for the year 2030 (2000:CHEM:2030:MFR).

Aerosol lifecycles are not independent as shown in previous studies (Stier et al., 2006a), e.g. specific emission changes induce changes in aerosol cycles with unaltered emissions. Therefore, estimates of sector- or regionwise impacts of aerosol emissions do not necessarily imply a linear response. To investigate the influence of this aerosol microphysical coupling we conducted two more experiments: one in which only $\mathrm{SO}_{2}$ emissions are assumed to change 
Table 3. Annual global mean aerosol properties for the different experiments (see Table 2 for a description of the experiments). The source of $\mathrm{SO}_{2}$ comprises primary emissions as well as $\mathrm{SO}_{2}$ derived from DMS oxidation. AOD denotes the Aerosol Optical Depth and AAOD the Aerosol Absorption Optical depth at $550 \mathrm{~nm}$; The microphysical aging is defined as the ratio of the column burden of the hydrophobic compounds to the transfer of the hydrophilic modes to the hydrophobic ones. Shortwave (SW) total aerosol RF is calculated relative to 2000 for the different experiments at the top of the atmosphere (TOA) in the atmosphere (atmopheric absorption ATM) and at the surface (SUR) both for clear-sky (CS) and total-sky (TS) conditions. Numbers in parenthesis are the percentage difference with respect to the 2000 simulation, i.e. 2000-PI in case of the PI experiment and EXP - 2000 for the future experiments with EXP $\in$ (MFR:2030, CLE:2030, MFR:2030:IP, MFR:2030:DT, MFR:2030:EUROPE, MFR:2030:ASIA).

\begin{tabular}{|c|c|c|c|c|c|c|c|c|c|}
\hline Experiment & & 2000 & PI & MFR:2030 & CLE:2030 & MFR:2030:IP & MFR:2030:DT & MFR:2030:EUROPE & MFR:2030:ASIA \\
\hline $\mathrm{SO}_{2}$ source & {$[\mathrm{Tg} / \mathrm{yr}]$} & 96.00 & $39.36(59)$ & $53.28(-44.5)$ & $99.55(3.7)$ & $61.92(-35.5)$ & $90.91(-5.3)$ & $97.92(0.2)$ & $76.99(-19.8)$ \\
\hline $\mathrm{SO}_{4}$ burden & {$[\mathrm{Tg}]$} & 0.86 & $0.40(55)$ & $0.53(-38)$ & $0.94(9)$ & $0.60(-30)$ & $0.86(0)$ & $0.92(7)$ & $0.71(-17)$ \\
\hline $\mathrm{SO}_{4}$ lifetime & [d] & 4.44 & $4.65(5)$ & $4.59(3)$ & $4.57(3)$ & $4.56(3)$ & $4.57(3)$ & $4.58(3)$ & $4.51(2)$ \\
\hline $\mathrm{BC}$ source & {$[\mathrm{Tg} / \mathrm{yr}]$} & 8.11 & $1.40(83)$ & $5.86(-28)$ & $7.21(-11)$ & $6.79(-16)$ & $6.28(-23)$ & $7.05(-13)$ & $6.56(-20)$ \\
\hline $\mathrm{BC}$ burden & {$[\mathrm{Tg}]$} & 0.12 & $0.03(75)$ & $0.10(-17)$ & $0.11(-8)$ & $0.11(-8)$ & $0.10(-17)$ & $0.11(-8)$ & $0.11(-8)$ \\
\hline BC lifetime & [d] & 5.56 & $7.06(-27)$ & $6.13(10)$ & $5.76(4)$ & $5.94(7)$ & $5.93(7)$ & $5.82(5)$ & $5.96(7)$ \\
\hline $\mathrm{BC}$ agingtime & [d] & 0.79 & $1.80(-128)$ & $1.12(42)$ & $0.79(0)$ & $1.02(30)$ & $0.88(10)$ & $0.83(5)$ & $0.96(21)$ \\
\hline POM source & {$[\mathrm{Tg} / \mathrm{yr}]$} & 69.14 & $33.96(51)$ & $60.36(-13)$ & $63.53(-8)$ & $63.03(-9)$ & $60.86(-12)$ & $63.13(-9)$ & $61.88(-11)$ \\
\hline POM burden & {$[\mathrm{Tg}]$} & 1.08 & $0.47(56)$ & $0.97(-10)$ & $1.00(-6)$ & $1.01(-7)$ & $0.99(-8)$ & $1.00(-7)$ & $0.99(-8)$ \\
\hline POM lifetime & [d] & 5.68 & $5.00(12)$ & $5.89(4)$ & $5.78(2)$ & $5.82(3)$ & $5.86(3)$ & $5.79(2)$ & $5.85(3)$ \\
\hline POM agingtime & [d] & 1.41 & $1.97(-40)$ & $1.64(16)$ & $1.33(-6)$ & $1.61(14)$ & $1.37(3)$ & $1.36(-4)$ & $1.44(2)$ \\
\hline AOD & [] & 0.162 & $0.121(25)$ & $0.136(-16)$ & $0.166(+2)$ & $0.141(-13)$ & $0.160(-1)$ & $0.164(1)$ & $0.151(-7)$ \\
\hline AAOD & {$[* 100]$} & 0.220 & $0.078(65)$ & $0.181(-19)$ & $0.206(-7)$ & $0.198(-10)$ & $0.190(-14)$ & $0.205(-7)$ & $0.195(-11)$ \\
\hline Forcing TOA TS & {$\left[\mathrm{W} / \mathrm{m}^{2}\right]$} & & -2.00 & 1.13 & 0.02 & 0.76 & 0.18 & 0.00 & 0.32 \\
\hline Forcing TOA CS & {$\left[\mathrm{W} / \mathrm{m}^{2}\right]$} & & -0.82 & 0.58 & -0.10 & 0.45 & 0.02 & -0.07 & 0.23 \\
\hline Forcing SUR TS & {$\left[\mathrm{W} / \mathrm{m}^{2}\right]$} & & -2.81 & 1.37 & 0.07 & 0.90 & 0.33 & 0.06 & 0.44 \\
\hline Forcing SUR CS & {$\left[\mathrm{W} / \mathrm{m}^{2}\right]$} & & -1.44 & 0.75 & -0.04 & 0.54 & 0.16 & 0.00 & 0.34 \\
\hline Forcing ATM TS & {$\left[\mathrm{W} / \mathrm{m}^{2}\right]$} & & 0.76 & -0.24 & -0.05 & -0.14 & -0.15 & -0.06 & -0.12 \\
\hline Forcing ATM CS & {$\left[\mathrm{W} / \mathrm{m}^{2}\right]$} & & 0.62 & -0.17 & -0.06 & -0.09 & -0.14 & -0.07 & -0.11 \\
\hline
\end{tabular}

according to the MFR 2030 scenario and BC and POM emission remain at the 2000 levels (CARBON:2000) and one in which $\mathrm{SO}_{2}$ emissions remain at the 2000 levels and $\mathrm{BC}$ and POM emissions change according to the MFR 2030 scenario (SULFATE:2000).

\section{Results}

In the following we focus on changes in the aerosol and aerosol precursor emissions, aerosol burdens and the resulting total aerosol radiative forcing (RF) relative to 2000 , i.e. (2000-pre-industrial) and (2030-2000).

\subsection{Aerosol emissions}

Global annual mean total aerosol emissions are given in Tables 3-5. For $\mathrm{SO}_{2}$ the source is the sum of primary emissions and $\mathrm{SO}_{2}$ derived from DMS oxidation. The differences of the single scenarios to the 2000 scenario are shown as zonal annual means in Fig. 1a-c together with the simulated changes in the respective aerosol burdens (Fig. 1d-f). Regional budgets for all experiments and the annual mean global distribution for the 2000 experiment (2000) are given in the appendix (Table A1 and Fig. A2).

Sea Salt, dust and DMS emissions are simulated interactively in all experiments. Since the nudging technique allows small variations of e.g. the simulated wind speed and temperature they vary slightly between the different experiments (less than $\pm 0.5 \%$ ). We do not further consider these variations in the discussion of the results.

In the CLE:2030 experiment the global annual mean $\mathrm{SO}_{2}$ source increases by $4 \%$ with reductions over Europe (OECD Europe $-34 \%$, Eastern Europe $-61 \%)$ and USA $(-6 \%)$ and increases in South Asia (+192\%), South East Asia (+98\%) and Africa (e.g. Southern Africa $+0.1 \%$, Northern Africa $+16.5 \%)$. BC and POM emission decrease globally with $-11 \%$ and $-8 \%$, respectively. In the MFR:2030 experiment the $\mathrm{SO}_{2}$ source and $\mathrm{BC}$ and $\mathrm{POM}$ emissions are reduced globally by $-45 \%,-28 \%$ and $-13 \%$, respectively. The magnitude of the $\mathrm{SO}_{2}$ source reduction in MFR:2030 is comparable with the $59 \%$ lower $\mathrm{SO}_{2}$ source in pre-industrial times compared to present day times. For BC and POM emissions, pre-industrial values were $+83 \%$ and $+51 \%$ lower than present, which is much larger than the emission reductions in CLE:2030 and MFR:2030. This is due to lower BC and POM biomass burning emissions in pre-industrial times, whereas in the future scenarios they are kept constant.

In the sectoral experiments the emission differences reflect the sector contribution to the total emissions. Industry and powerplant emissions dominate the total $\mathrm{SO}_{2}$ emissions while domestic and transport emissions are more important 
Table 4. As Table 3.

\begin{tabular}{|c|c|c|c|c|c|c|c|}
\hline Experiment & & MFR:2030 & MFR:2030:CHEM:2000 & CLE:2030 & CLE:2030:CHEM:2000 & 2000 & 2000:CHEM:2030:MFR \\
\hline $\mathrm{SO}_{2}$ source & {$[\mathrm{Tg} / \mathrm{yr}]$} & 53.28 & 53.30 & 99.55 & 99.50 & 96.0 & 96.1 \\
\hline $\mathrm{SO}_{4}$ burden & {$[\mathrm{Tg}]$} & 0.53 & 0.52 & 0.94 & 0.94 & 0.86 & 0.86 \\
\hline $\mathrm{SO}_{4}$ lifetime & [d] & 4.59 & 4.58 & 4.57 & 4.56 & 4.44 & 4.42 \\
\hline BC source & {$[\mathrm{Tg} / \mathrm{yr}]$} & 5.86 & 5.86 & 7.21 & 7.21 & 8.11 & 8.11 \\
\hline $\mathrm{BC}$ burden & {$[\mathrm{Tg}]$} & 0.10 & 0.10 & 0.11 & 0.11 & 0.12 & 0.12 \\
\hline BC lifetime & [d] & 6.13 & 6.13 & 5.76 & 5.76 & 5.56 & 5.57 \\
\hline POM source & {$[\mathrm{Tg} / \mathrm{yr}]$} & 60.36 & 60.36 & 63.53 & 63.53 & 69.14 & 69.14 \\
\hline POM burden & {$[\mathrm{Tg}]$} & 0.97 & 0.97 & 1.00 & 1.00 & 1.08 & 1.1 \\
\hline POM lifetime & [d] & 5.89 & 5.89 & 5.78 & 5.78 & 5.68 & 5.69 \\
\hline AOD & [] & 0.136 & 0.136 & 0.166 & 0.166 & 0.162 & 0.162 \\
\hline Forcing TOA TS* & {$\left[\mathrm{W} / \mathrm{m}^{2}\right]$} & 1.13 & 1.20 & 0.02 & -0.04 & 2.00 & 2.11 \\
\hline Forcing TOA CS* & {$\left[\mathrm{W} / \mathrm{m}^{2}\right]$} & 0.58 & 0.58 & -0.10 & -0.11 & 0.82 & 0.82 \\
\hline Forcing SUR TS* & {$\left[\mathrm{W} / \mathrm{m}^{2}\right]$} & 1.37 & 1.44 & -0.07 & -0.05 & 2.81 & 2.87 \\
\hline Forcing SUR CS* & {$\left[\mathrm{W} / \mathrm{m}^{2}\right]$} & 0.75 & 0.74 & -0.04 & 0.01 & 1.44 & 1.44 \\
\hline Forcing ATM TS* & {$\left[\mathrm{W} / \mathrm{m}^{2}\right]$} & -0.24 & -0.24 & 0.09 & -0.05 & -0.76 & -0.76 \\
\hline Forcing ATM CS* & {$\left[\mathrm{W} / \mathrm{m}^{2}\right]$} & -0.17 & -0.16 & -0.06 & 0.01 & -0.62 & -0.62 \\
\hline
\end{tabular}

* For 2000 and 2000:CHEM:2030:MFR the forcing is calculated relative to the experiment PI.

Table 5. As Table 3.

\begin{tabular}{|c|c|c|c|c|c|}
\hline Experiment & & 2000:CHEM:2030:MFR & MFR:2030 & SULFATE:2000 & CARBON:2000 \\
\hline $\mathrm{SO}_{2}$ source & {$[\mathrm{Tg} / \mathrm{yr}]$} & 96.1 & 53.29 & 93.94 & 52.30 \\
\hline $\mathrm{SO}_{4}$ burden & {$[\mathrm{Tg}]$} & 0.86 & 0.53 & 0.85 & 0.53 \\
\hline $\mathrm{SO}_{4}$ lifetime & [d] & 4.43 & 4.59 & 4.40 & 4.60 \\
\hline $\mathrm{BC}$ source & {$[\mathrm{Tg} / \mathrm{yr}]$} & 8.11 & 5.86 & 5.86 & 8.11 \\
\hline $\mathrm{BC}$ burden & {$[\mathrm{Tg}]$} & 0.12 & 0.10 & 0.10 & 0.13 \\
\hline BC lifetime & [d] & 5.57 & 6.13 & 6.05 & 5.68 \\
\hline aging time & [d] & 0.82 & 1.13 & 0.91 & 1.09 \\
\hline POM source & {$[\mathrm{Tg} / \mathrm{yr}]$} & 69.14 & 60.36 & 60.36 & 69.14 \\
\hline POM burden & {$[\mathrm{Tg}]$} & 1.08 & 0.97 & 0.97 & 1.09 \\
\hline POM lifetime & [d] & 5.68 & 5.89 & 5.86 & 5.74 \\
\hline aging time & [d] & 1.46 & 1.64 & 1.35 & 1.89 \\
\hline AOD & [] & 0.162 & 0.136 & 0.160 & 0.137 \\
\hline Forcing TOA TS* & {$\left[\mathrm{W} / \mathrm{m}^{2}\right]$} & & 1.18 & 0.07 & 1.08 \\
\hline Forcing TOA CS* & {$\left[\mathrm{W} / \mathrm{m}^{2}\right]$} & & 0.53 & -0.05 & 0.53 \\
\hline Forcing SUR TS* & {$\left[\mathrm{W} / \mathrm{m}^{2}\right]$} & & 1.37 & 0.18 & 1.10 \\
\hline Forcing SUR CS* & {$\left[\mathrm{W} / \mathrm{m}^{2}\right]$} & & 0.75 & 0.17 & 0.59 \\
\hline Forcing ATM TS* & {$\left[\mathrm{W} / \mathrm{m}^{2}\right]$} & & -0.19 & -0.11 & -0.02 \\
\hline Forcing ATM CS* & {$\left[\mathrm{W} / \mathrm{m}^{2}\right]$} & & -0.22 & -0.22 & -0.06 \\
\hline
\end{tabular}

* The total aerosol radiative forcing is calculated relative to the experiment 2000:CHEM:2030:MFR.

sources for $\mathrm{BC}$ and POM emissions. Therefore, in the MFR:2030:IP experiment, the $\mathrm{SO}_{2}$ source is strongly reduced and shows similarity with the MFR:2030 experiment, whereas BC and POM emissions show a comparable decrease with the CLE:2030 experiment. The MFR:2030:DT experiment shows only a small change in the $\mathrm{SO}_{2}$ source (comparable to CLE:2030) and BC and POM emissions are strongly reduced, similar to MFR:2030. In the case aerosol emissions are reduced over Europe according to MFR 2030 (MFR:2030:EUROPE) the $\mathrm{SO}_{2}$ source still increases 
(a) Emission Sulfur

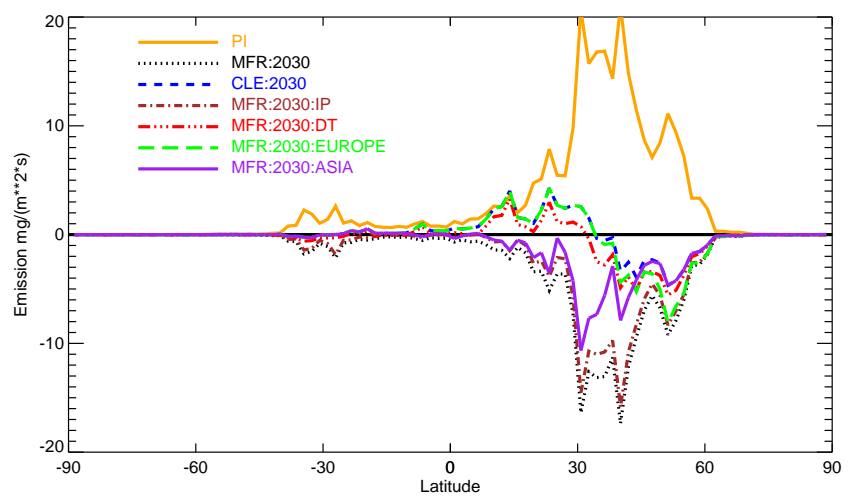

(b) Emission BC

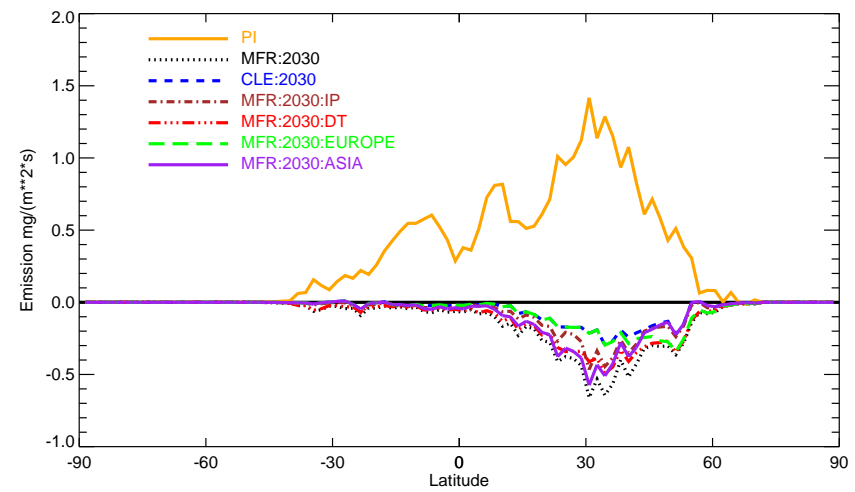

(c) Emission POM

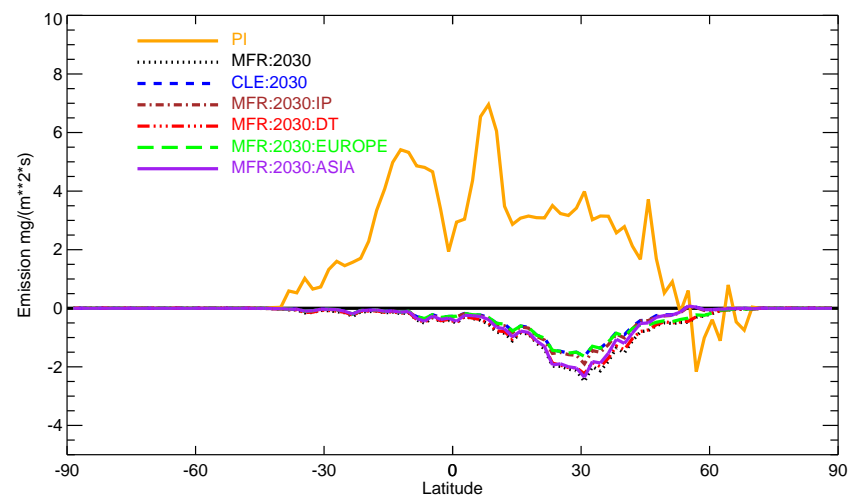

(d) Burden $\mathrm{SO}_{4}$

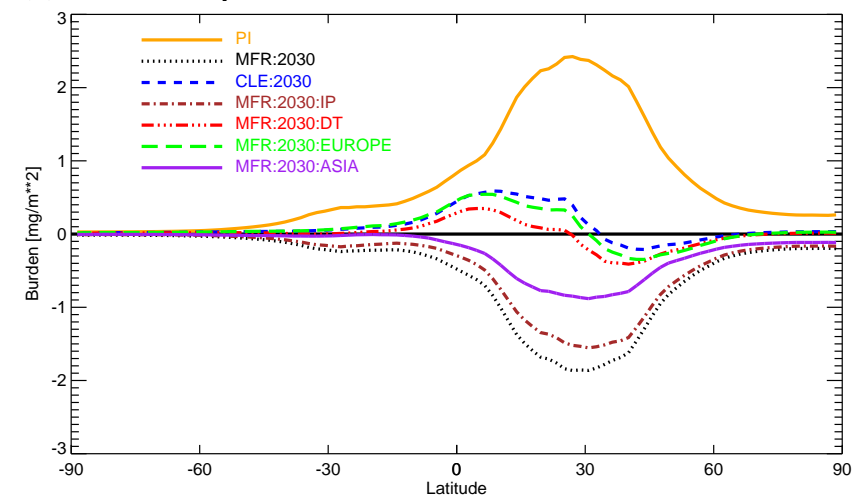

(e) Burden BC

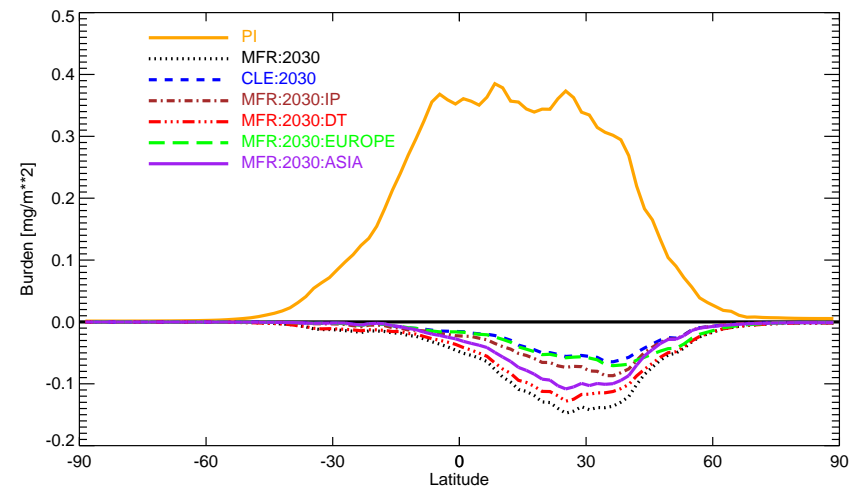

(f) Burden POM

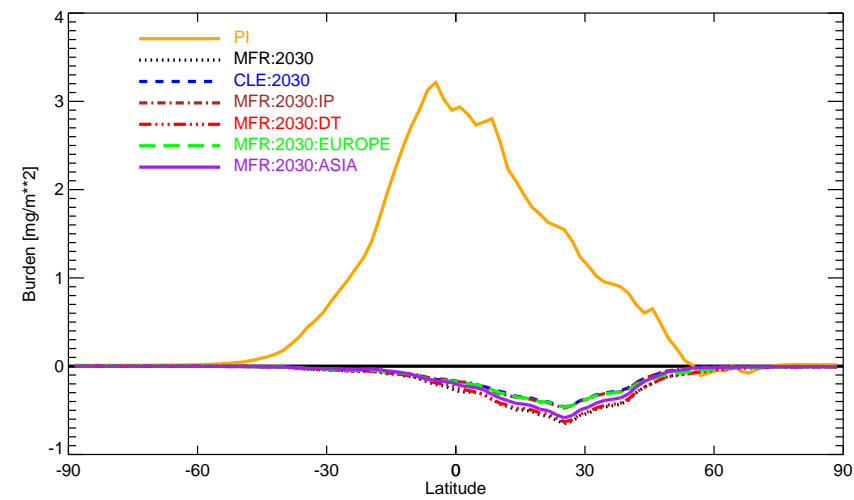

Fig. 1. Annual zonal mean total (natural and anthropogenic) aerosol and aerosol precursor emission (panel (a) $-(\mathbf{c}))\left[\mathrm{mg} /\left(\mathrm{m}^{2} * \mathrm{~s}\right)\right]$ and aerosol burdens (panel (d)-(f) $\left[\mathrm{mg} /\left(\mathrm{m}^{2}\right)\right]$ for the single scenarios relative to 2000 , i.e. 2000-PI in case of the PI experiment reflecting mainly increasing aerosol and aerosol precursor emissions in the past and EXP-2000 for the future experiments reflecting future changes in aerosol and aerosol precursor emissions with EXP $\in$ (MFR:2030, CLE:2030, MFR:2030:IP, MFR:2030:DT, MFR:2030:EUROPE, MFR:2030:ASIA).

globally $(+0.2 \%)$ due to the increase over Asia which is not completely compensated by the decrease over Europe. In contrast, global annual mean BC and POM emission decrease (BC:-13\%; POM:-9\%), but to a much lesser extent than in the MFR:2030 scenario, reflecting that current legislation does not strongly reduce BC and POM emissions in 2030 except over Europe. In contrast, the MFR:2030:ASIA scenario shows a strong decrease of the $\mathrm{SO}_{2}$ source and $\mathrm{BC}$ and POM emissions $(-20 \%,-20 \%,-11 \%$, respectively), reflecting the high potential to reduce aerosol emissions over Asia assuming that all currently available aerosol emission abatements will be implemented. 


\subsection{Aerosol burden and aerosol optical depth}

The annual zonal mean aerosol burdens for $\mathrm{SO}_{4}, \mathrm{BC}$ and POM for the different experiments compared to 2000 are displayed in Fig. 1d-f. The global annual mean burdens are given in Table 3. Regional budgets for all experiments and the global annual mean distribution for the present-day experiment (2000) are given in the appendix (Table A1 and Fig. A2).

The burdens do not respond linearly to the emission changes as reflected in the altered aerosol lifetimes. Aerosol lifetime (defined as the ratio of global mean burden to global mean source) is influenced by changes of the source distribution as well as changes in the aerosol and oxidant composition. The influence of changes in the aerosol composition are reflected in the changes of the microphysical aging time of BC and POM. The microphysical aging time is defined as the ratio of the burden of the hydrophobic aerosol compounds divided by the rate with which hydrophobic aerosols are transfered to hydrophilic aerosols. For example in the MFR:2030 experiment the global $\mathrm{SO}_{4}$ burden decreases by $-38 \%$, which is $7 \%$ less than the emission reduction. This non linear response results from a longer lifetime $(+3 \%)$ in MFR:2030. The increase in $\mathrm{SO}_{4}$ lifetime is apparent in all experiments, which show a distinct shift of $\mathrm{SO}_{2}$ emissions towards low-latitude regions. Aerosol lifetime is influenced by a number of competing and interacting mechanism. Graf et al. (1997) showed that natural emitted $\mathrm{SO}_{2}$ from volcanoes and DMS in the low latitudes have a longer lifetime compared to anthropogenic emissions in high-latitude regions caused by less efficient dry deposition. Stier et al. (2006c) showed a similar response as simulated in this study for a shift of anthropogenic emissions towards lower latitudes, going along with a strong increase in aerosol burden over semiarid tropical regions (Fig. 1d).

Stronger non-linear effects are found for the BC and POM burden in the MFR:2030 experiments where the burden (BC:-17\%; POM:-10\%) decreases much less than the emissions (BC:-28\%; POM:-13\%). This can be explained by an increase in the microphysical aging time of $\mathrm{BC}$ and POM $\left(+42 \%\right.$ and $+16 \%$, respectively) caused by less $\mathrm{SO}_{2}$ emissions in the MFR:2030 scenario, removing less BC and POM by wet deposition and increasing its lifetime. For POM this effect is less pronounced as $65 \%$ of the POM sources are already assumed to be hydrophilic in ECHAM5-HAM (Stier et al., 2006b).

Overall, the strong decrease of $\mathrm{SO}_{2}$ in the MFR:2030 experiment leads to a reduction of the aerosol optical depth (AOD, here defined as column integrated aerosol extinction at $550 \mathrm{~nm}$ ) of $16 \%$ compared to 2000 . This is half of the increase of the AOD $(+34 \%)$ between pre-industrial and present-day times. In contrast, CLE:2030 leads to a further increase $(+2 \%)$ of the AOD globally, which is mainly driven by higher AODs over Asia.
The aerosol absorption optical depth (AAOD, here defined as the column integrated aerosol extinction owing to absorption at $550 \mathrm{~nm}$ ), decreases around 20\% in the MFR:2030 experiment, which is much less than the $182 \%$ increase between pre-industrial and present day. This is caused by the assumption of constant future biomass burning emissions, in contrast to reduced biomass burning emissions in the preindustrial experiment. The annual mean global AAOD is reduced in all experiments, as BC and POM emissions decrease in the CLE 2030 as well as MFR 2030 scenario worldwide.

From the regional experiments (MFR:2030:EUROPE and MFR:2030:ASIA) we can analyse to what extent a maximum feasible reduction of aerosol and aerosol precursor emissions in Europe or Asia affects other regions of the world by comparing with the CLE:2030 experiment. In case MFR is applied only in Europe we find slightly reduced AODs in other world regions (e.g. AODs over USA and the Middle East are decreasing by $-3 \%$ ). In contrast, when MFR is only applied in Asia reduced AODs can be found most pronounced over adjacent regions like Japan $(-27 \%)$. Strong reductions are also simulated for more remote regions (e.g. USA:-7\%, Europe $(\mathrm{OECD}):-3 \%)$, reflecting the large export of aerosols from Asia into this regions. The reduction in AODs are mainly driven by reduced $\mathrm{SO}_{4}$ burdens (see also Table A1 in the appendix).

In addition, the regional experiments can be compared to the MFR:2030 experiment. The difference reflects the extent to which Europe or Asia will benefit from a maximum feasible reduction of aerosol and aerosol precursor emissions applied in all other regions of the world. For Europe the AOD is reduced additionally by $10 \%$ caused by a reduced $\mathrm{SO}_{4}$ burden $(-23 \%)$. Also Asia benefits from a worldwide application of MFR 2030. The AOD over Asia will be reduced further by $15 \%$ mainly caused by an additional decrease in the $\mathrm{SO}_{4}$ burden $(-19 \%)$.

\subsection{Aerosol radiative forcing}

We calculate the present-day anthropogenic top-of-theatmosphere (TOA) radiative forcing (RF) as the difference between the present day simulation (2000) and the preindustrial simulation (PI), hereinafter referred to as TOA RF (2000-PI). Analogously, the future changes are defined as TOA RF (2030-2000). The calculated RF includes the contributions from the direct aerosol effect, the cloud albedo effect, the cloud lifetime effect and the semi-direct effect on the shortwave radiation. We note that our method of aerosol RF calculations does not strictly follow the definition of IPCC (Forster et al., 2007) since here it includes contributions from the cloud lifetime effect. We also diagnosed the atmospheric absorption, which is the difference in net solar radiation between TOA and surface and the surface RF. RFs are calculated for clear sky conditions and total-sky conditions. In the following, numbers always refer to total-sky RF. 
The global annual mean total (direct plus indirect) aerosol RFs for the different experiments are summarized in Table 3 and plotted as zonal annual means in Fig. 2 together with the changes in the liquid water path, cloud top effective radius and total cloud cover. Regional budgets of the TOA RF are given in the appendix (Table A1) and annual mean global distributions of the RF for the baseline experiments are shown in the appendix (Fig. A3)

The present day total anthropogenic TOA RF (2000-PI) is simulated as $-2.0 \mathrm{~W} / \mathrm{m}^{2}$. This is on the higher end of recent estimates from global climate models with a range of -0.2 and $-2.3 \mathrm{~W} / \mathrm{m}^{2}$ and an average of $-1.2 \mathrm{~W} / \mathrm{m}^{2}$ (Denman et al., 2007). It is slightly higher than the $-1.8 \mathrm{~W} / \mathrm{m}^{2}$ simulated with an almost identical model version, but applying AeroCom 2000 emissions (Lohmann et al., 2007).

The total anthropogenic TOA RF of $-2.0 \mathrm{~W} / \mathrm{m}^{2}$ goes along with an increase in the liquid water path and cloud cover. This results from the aerosol cloud lifetime effect, which retards the rain formation by the formation of smaller cloud droplets (decrease in cloud droplet radius) causing a build-up of cloud water. This effect is most pronounced in the region with a high anthropogenic aerosol load $\left(30^{\circ}-\right.$ $\left.60^{\circ} \mathrm{N}\right)$.

For all future experiments a positive TOA RF (2030$2000)$ is simulated. Thus, the negative present-day anthropogenic TOA RF of $-2.0 \mathrm{~W} / \mathrm{m}^{2}$ will be reduced in the future caused by air pollution mitigation. For the future experiments MFR:2030 and CLE:2030 the simulated TOA RF are $1.13 \mathrm{~W} / \mathrm{m}^{2}$ and $0.02 \mathrm{~W} / \mathrm{m}^{2}$, respectively. Regionally, the RFs are quite inhomogeneous. In case of the MFR:2030 experiment the total aerosol TOA RF is positive globally with the largest values (up to $2.5 \mathrm{~W} / \mathrm{m}^{2}$ ) around $30^{\circ} \mathrm{N}$ caused by the strong decrease of $\mathrm{SO}_{2}$ emissions over Asia and North America in the future. In contrast, the CLE:2030 experiment leads to a slightly negative RF between the equator and $30^{\circ} \mathrm{N}$ caused by the increase in $\mathrm{SO}_{2}$ emission over Asia, whereas it is positive $\left(\sim 0.5 \mathrm{~W} / \mathrm{m}^{2}\right)$ around $40^{\circ}-60^{\circ} \mathrm{N}$ caused by a decrease in aerosol emission over Europe in the future.

The MFR:2030:IP experiment leads to a TOA RF (20302000) of $0.76 \mathrm{~W} / \mathrm{m}^{2}$, caused by the decrease in $\mathrm{SO}_{2}$ emissions. In the case that only the aerosol emission in the Transport and Domestic sector are reduced to a maximum feasible extent (MFR:2030:DT) the TOA RF amounts to $0.18 \mathrm{~W} / \mathrm{m}^{2}$. Thereby, the reduction in BC and POM emissions leads to a total negative aerosol $\mathrm{RF}$ in the atmosphere of the same magnitude $\left(-0.15 \mathrm{~W} / \mathrm{m}^{2}\right)$.

If only Europe will follow a maximum feasible reduction strategy in the future (MFR:2030:EUROPE) the total aerosol global annual mean TOA RF (2030-2000) amounts to $0.00 \mathrm{~W} / \mathrm{m}^{2}$. Thus, a maximum feasible reduction of aerosol and aerosol precursor emissions over Europe leads only to a small additional negative global annual mean TOA RF $\left(-0.02 \mathrm{~W} / \mathrm{m}^{2}\right)$ compared to the case in which worldwide CLE 2030 is applied (CLE:2030). A comparison with the MFR:2030 experiment shows that the TOA RF will be $52 \%$ higher over Europe in the case MFR 2030 is not only applied over Europe but worldwide.

In contrast, an implementation of a maximum feasible reduction strategy in Asia (MFR:2030:ASIA) leads to a strong positive TOA RF (2030-2000) across Asia (up to $+6 \mathrm{~W} / \mathrm{m}^{2}$ ). The global annual mean TOA RF amounts to $+0.32 \mathrm{~W} / \mathrm{m}^{2}$. This is substantially higher than the $+0.02 \mathrm{~W} / \mathrm{m}^{2}$ simulated in the CLE:2030 experiment, reflecting the large potential to reduce aerosol and aerosol-precursor emissions in Asia. Compared to the MFR:2030 experiment the positive TOA RF is $23 \%$ higher over Asia when MFR 2030 is not applied only for Asia but worldwide.

\section{Sensitivity studies}

This study provides estimates of the radiative effect of future aerosol and aerosol precursor emission mitigation strategies. The resulting aerosol burdens and RFs are determined by simultaneously changing chemical and aerosol microphysical conditions. In the sensitivity studies below we try to disentangle the role of two important processes: the effects of changes in the oxidant concentrations and the effects of changes in the aerosol composition.

\subsection{Influence of oxidant concentrations}

To investigate the sensitivity of our results to changes in prescribed offline oxidant concentrations, we performed three additional experiments: two studies consider changes of aerosol emissions according to MFR 2030 and CLE 2030, with oxidant concentrations at the 2000 level (CLE:2030:CHEM:2000, MFR:2030:CHEM:2000) instead of oxidant concentrations for the respective scenarios as used in the experiments CLE:2030 and MFR:2030 discussed in the previous chapter. In the third study aerosol and aerosol precursor emissions remain at 2000 levels, whereas oxidant concentrations change according to the MFR scenario (2000:CHEM:2030:MFR). We consider that these studies encompass a realistic range of possible anthropogenic oxidant changes until 2030.

The oxidant concentrations as simulated in TM3 show large regional variations for the different scenarios (Dentener et al., 2006b). In Table A2 in the appendix we present a regional analysis of the changes in oxidant burdens for the different experiments. Different oxidant concentrations will alter the production of $\mathrm{SO}_{4}$ in the gas-phase as well as in the aqueous-phase. Thereby, the relative contribution of gasand aqueous-phase production to the total production varies regionally. For example over Europe $\mathrm{SO}_{4}$ production is dominated by aqueous-phase production and is therefore sensitive to changes in $\mathrm{H}_{2} \mathrm{O}_{2}$ and $\mathrm{O}_{3}$ concentrations, whereas gasphase production is dominant over dry regions as desert regions in Africa or the Middle East, making $\mathrm{SO}_{4}$ production highly sensitive to $\mathrm{OH}$ concentrations. Regional budgets for 
(a) TOA SW Forcing

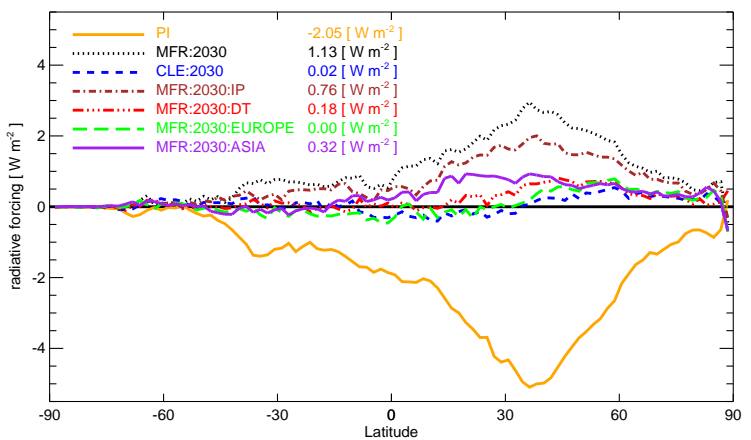

(b) Atmospheric SW Absorption

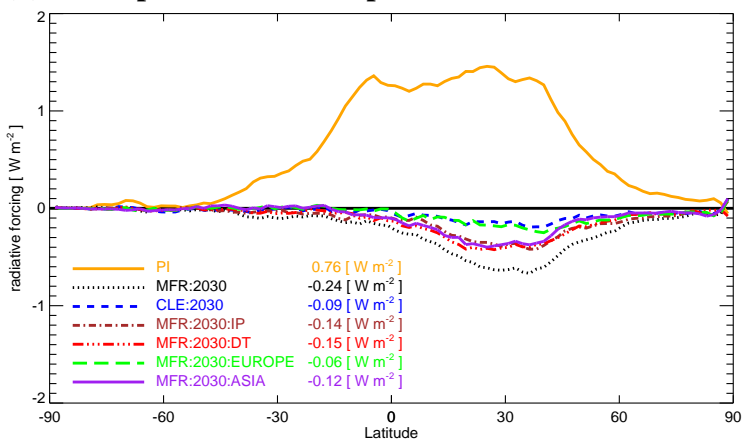

(c) Surface SW Forcing

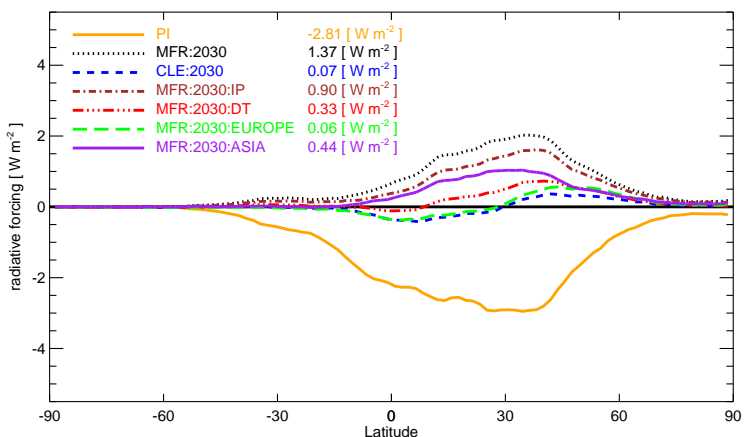

(d) AOD

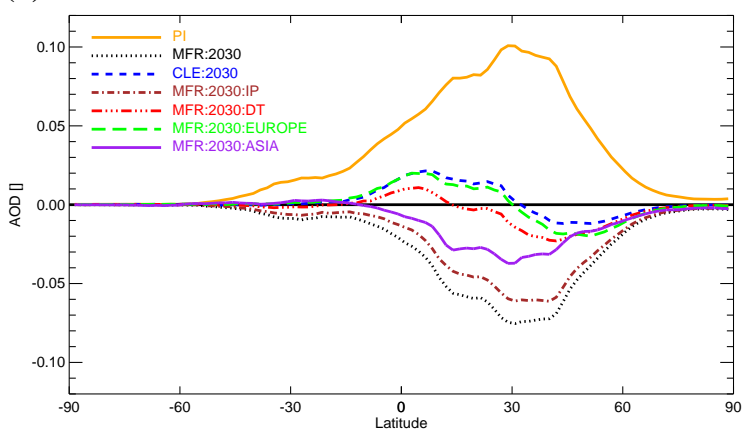

(e) Liquid Water Path

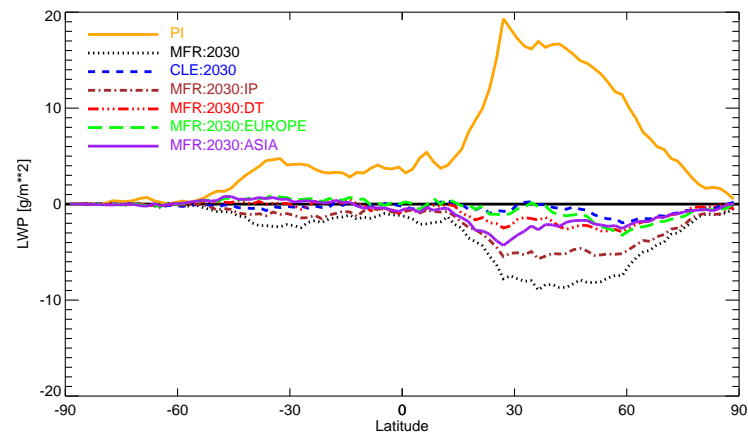

(f) Cloud Cover

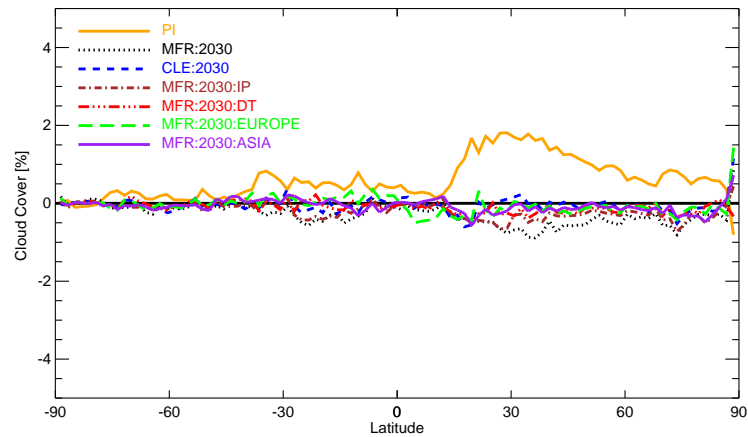

(g) Cloud top effective radius

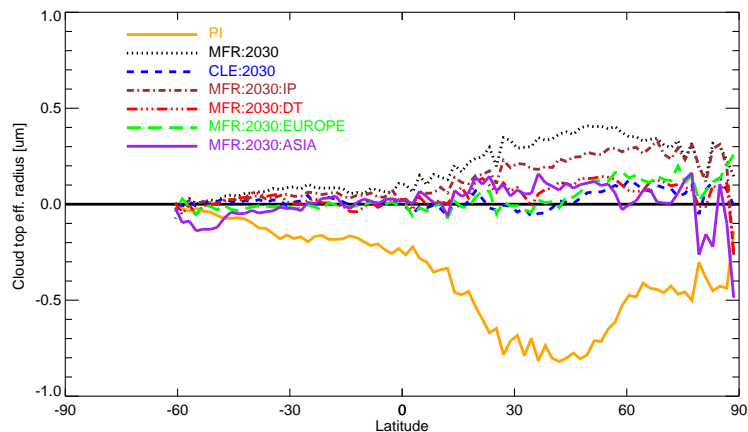

(h) AAOD

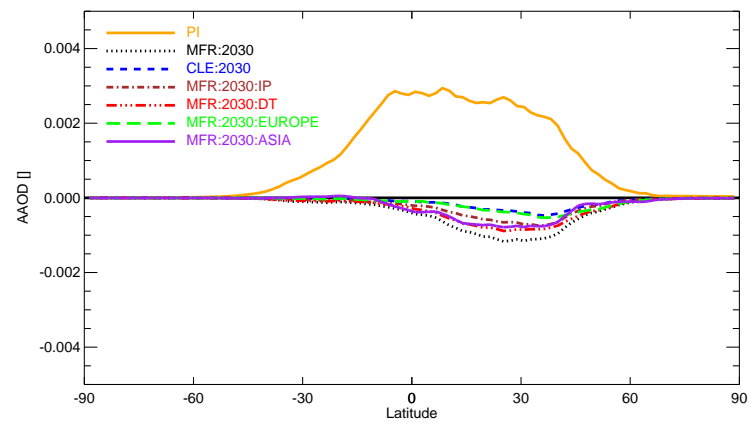

Fig. 2. Annual zonal mean changes of the total aerosol radiative forcing (RF) at the top of the atmosphere (TOA), within the atmosphere (atmospheric absorption) and at the surfaces $\left[\mathrm{W} / \mathrm{m}^{2}\right]$ in the shortwave $(\mathrm{SW})$, the Liquid Water Path $(\mathrm{LWP})\left[\mathrm{g} / \mathrm{m}^{2}\right]$, the aerosol optical depth at $550 \mathrm{~nm}$ (AOD) and the aerosol absorption optical depth at $550 \mathrm{~nm}$ (AAOD), the total Cloud Cover [\%] and the cloud top effective radius $[\mu \mathrm{m}]$ sampled only over cloudy periods within the cloudy part of the grid box. Differences are shown relative to the experiment 2000 , i.e. 2000-PI in case of the PI experiment, reflecting present-day anthropogenic total aerosol RF and EXP-2000 for the future experiments reflecting RF perturbations of the present-day anthropogenic total aerosol RF in the future with EXP $\in$ (MFR:2030, CLE:2030, MFR:2030:IP, MFR:2030:DT, MFR:2030:EUROPE, MFR:2030:ASIA). Numbers denote annual global mean RF. 
(a) CLE:2030:CHEM:2000-CLE:2030
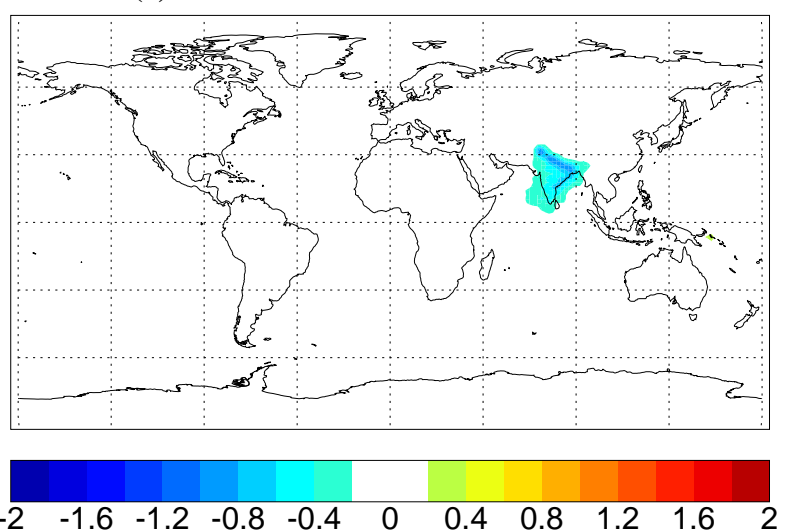

(c) 2000:CHEM:2030:MFR-2000
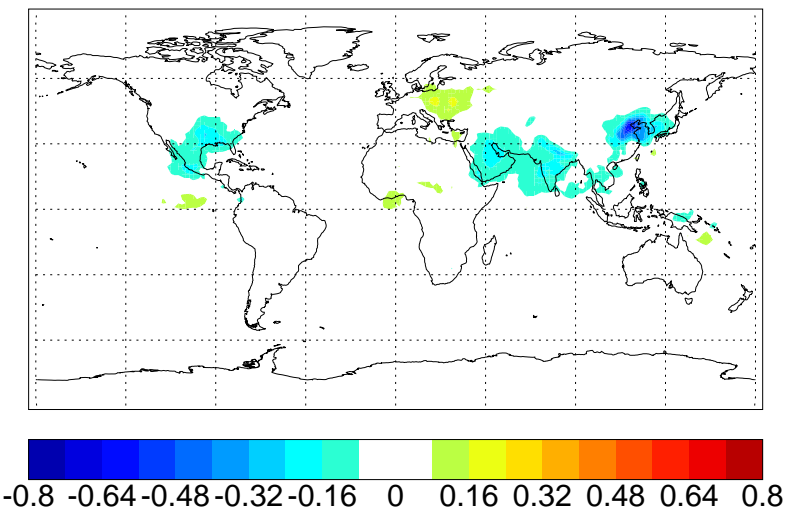

(b) MFR:2030:CHEM:2000-MFR:2030
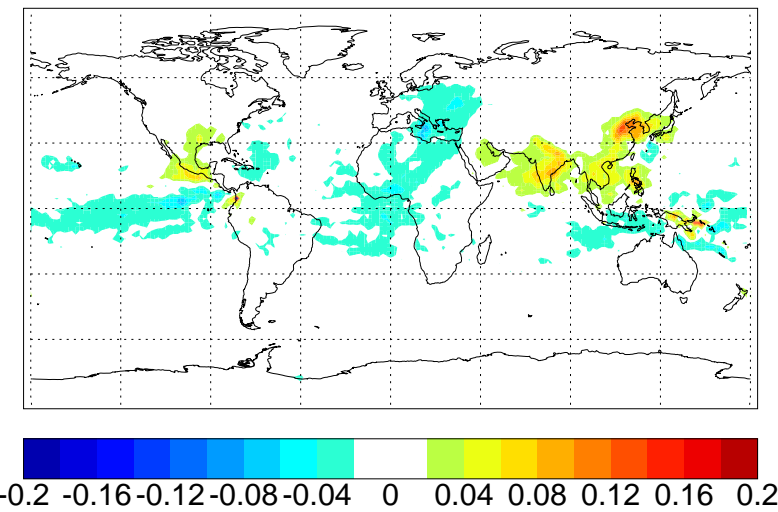

(d) Additivity
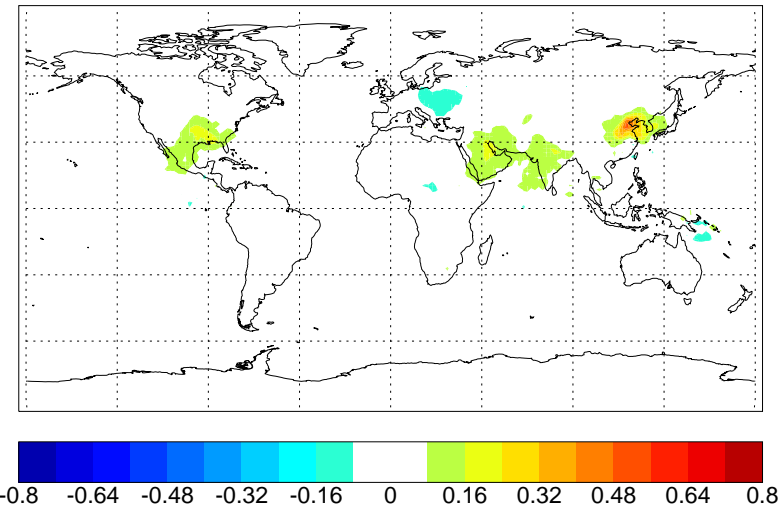

Fig. 3. Differences in $\mathrm{SO}_{4}$ burden in $\left[\mathrm{mg}(\mathrm{S}) / \mathrm{m}^{2}\right]$ caused by different oxidant concentrations (a)-(c). (d) The deviation from additivity, defined as the difference in the response (compared to the reference experiments) between the sum of the experiments in which oxidant concentration and aerosol and aerosol pre-cursor emssions changed individually ( $\Delta 2000$ :CHEM:2030:MFR+ $\triangle$ MFR:2030:CHE:2000) and the experiment in which both are changed at the same time ( $\triangle \mathrm{MFR}: 2030$ ). The total present day $\mathrm{SO}_{4}$ burden as simulated in the 2000 experiment is shown in the appendix Fig. A2d.

the gas- and aqueous-phase production of $\mathrm{SO}_{4}$ and the $\mathrm{SO}_{4}$ burden as simulated for the single experiments are given in Table A3 in the appendix.

If oxidant concentrations would remain identical to present day conditions, a situation that would be roughly representative for the absence of further mitigation measures to reduce ozone precursor emissions, we simulate only small impacts in the global annual mean $\mathrm{SO}_{4}$ burden (Table 4) for both aerosol and aerosol precursor emission scenarios (CLE 2030 and MFR 2030). However, regionally we find pronounced differences in the $\mathrm{SO}_{4}$ burden (Fig. 3a and b).

For CLE:2030:CHEM:2000 impacts are strongest over South Asia where the $\mathrm{SO}_{4}$ burden is $5 \%$ lower compared to CLE:2030. Here, the lower $\mathrm{OH}$ burden $(-2 \%)$ at present day levels leads to a weaker gas-phase production of $\mathrm{SO}_{4}$ $(-7 \%)$. A similar, but stronger effect, was found by Unger et al. (2006). For the SRES A1B emissions scenario they simulate that present oxidant levels compared to increased levels of oxidants in 2050 would lead to $20 \%$ lower $\mathrm{SO}_{2}$ oxidation rates over India and China. The decrease in $\mathrm{SO}_{4}$ burden dampens the overall increase of the $\mathrm{SO}_{4}$ burden over
South Asia due to higher $\mathrm{SO}_{2}$ emissions in the CLE 2030 scenario compared to 2000. Thus, the negative total aerosol TOA RF as simulated over South Asia is reduced (by $-8 \%$ for clear sky conditions).

Consistently, comparing MFR:2030:CHEM:2000 and MFR:2030 we find an increase in the $\mathrm{SO}_{4}$ burden (most pronounced over Asia $(+1.8 \%)$ and Central America (+1.3\%)) due to the higher $\mathrm{OH}$ levels in 2000 compared to MFR 2030 leading to a stronger gas-phase production of $\mathrm{SO}_{4}$. However, over Europe the $\mathrm{SO}_{4}$ burden is lower (1-2\%) as here $\mathrm{OH}$ as well as $\mathrm{H}_{2} \mathrm{O}_{2}$ concentrations are lower $(-(6-7 \%)$ and $-(0$ $10 \%$ ), respectively) in 2000 compared to MFR 2030 leading to a weaker gas-phase as well as aqueous-phase production of $\mathrm{SO}_{4}$. The increase in $\mathrm{SO}_{4}$ burden dampens the overall decrease in $\mathrm{SO}_{4}$ burden over Asia caused by decreasing $\mathrm{SO}_{2}$ emissions in the MFR 2030 scenario. Therefore, the positive total aerosol TOA RF as simulated over Asia is weaker ( $-2 \%$ for clear sky) in case 2000 oxidant concentrations are used. The opposite is the case for Europe where $\mathrm{SO}_{4}$ production rates are lower and thus amplify the $\mathrm{SO}_{2}$ emission trend and increase the positive total aerosol TOA RF. 
For the third sensitivity study which assumes that air pollution mitigation only effects photo-oxidant precursor emissions and leaves aerosol and aerosol precursor emissions unchanged in the future (2000:CHEM:2030:MFR) the changes in the $\mathrm{SO}_{4}$ burden are very similar but stronger and opposite in sign compared to the MFR sensitivity experiment (Fig. 3c).

As a result the combined response of changes in oxidant concentrations and aerosol and aerosol precursor emission changes are non-linear. Figure $3 d$ shows the additivity of the sulfate burden for the MFR:2030 case. Additivity is thereby defined as:

$$
\begin{aligned}
a & =(\triangle \mathrm{MFR}: 2030)-(\triangle 2000: \mathrm{CHEM}: 2030: \mathrm{MFR} \\
& +\triangle \mathrm{MFR}: 2030: \mathrm{CHEM}: 2000)
\end{aligned}
$$

with $\Delta X=X-\mathrm{REF}$ and $X \in$

(MFR:2030,2000:CHEM:2030:MFR, MFR:2030:CHEM:2000);

REF is the reference experiment 2000.

A negative deviation from additivity implies that the decrease in sulfate burden is higher in the sum of the individual experiments ( 2 2000:CHEM:2030:MFR+AMFR:2030:CHEM:2000),

in which aerosol emissions and oxidant concentration are changed separately, than in the combined experiment ( $\triangle$ MFR:2030). A positive deviation implies that the decrease in sulfate burden is lower in the sum of the individual experiments than in the combined experiment. We find positive deviations reaching up to $0.48 \mathrm{mg}(\mathrm{S}) / \mathrm{m}^{2}$ ( $3 \%$ compared to the reference simulation) over Asia and parts of North America. Parts of Europe show slightly negative deviations $\left(-0.16 \mathrm{mg}(\mathrm{S}) / \mathrm{m}^{2}, 4 \%\right.$ compared to the reference simulation). Deviations from additivity result from a stronger response of the sulfate burden towards changes in oxidant concentrations in the case aerosol and aerosol precursor emissions remain at their high present day values (2000:CHEM:2030:MFR) compared to the response when aerosol and aerosol precursor emissions are reduced (MFR:2030, compare Fig. 3b and 3c). On the global annual mean the deviation from additivity is rather small (1.8 $\mathrm{Gg}(\mathrm{S}), \quad 0.2 \%$ of the sulfate burden simulated for the reference simulation).

For all sensitivity experiments the changes in $\mathrm{SO}_{4}$ concentrations do not substantially alter the lifetime of the other aerosol compounds considered $(<1 \%$, see Table 4$)$. The global annual mean total aerosol TOA RF (2030-2000) is thereby only slightly affected: for CLE:2030:CHEM:2000 it amounts to $-0.04 \mathrm{~W} / \mathrm{m}^{2}$ compared to $+0.02 \mathrm{~W} / \mathrm{m}^{2}$ for CLE:2030; for MFR:2030:CHEM:2000 it amounts to $+1.20 \mathrm{~W} / \mathrm{m}^{2}$ compared to $+1.13 \mathrm{~W} / \mathrm{m}^{2}$ for MFR: 2030 .

Finally we wish to mention that we do not simulate the strong changes in the vertical distribution of $\mathrm{SO}_{4}$ concentration and $\mathrm{SO}_{4}$ deposition processes nor substantial changes in DMS, as were found by Pham et al. (2005). The latter authors focused on the extreme SRES A2 scenario, which assumes especially for precursors of ozone much stronger increases than the scenario considered here, for instance global $\mathrm{NO}_{\mathrm{x}}$ emissions increase from 2000 to 2030 for SRES A2 by $+101 \%$, whereas they decrease for CLE and MFR by $-4 \%$ and $-60 \%$, respectively. Although the SRES A2 scenario is nowadays considered to be overly pessimistic (Dentener et al., 2006b), the Pham et al. (2005) study offers an interesting perspective on what could be the consequence of nonattainment to air quality objectives.

\subsection{Changes in aerosol composition}

Aerosols are predominantly internally mixed, with varying chemical composition. The microphysical aging of aerosols, determined by the growth of aerosols by coagulation, condensation of gas-phase sulfate on pre-existing aerosol particles and by cloud processing, affects their size distribution, solubility and radiative properties. Therefore, aerosol lifecycles of different components are not independent, i.e. changes in aerosol and aerosol precursor emissions of a specific compound can affect other aerosol compounds and change the overall aerosol microphysical and radiative properties (Stier et al., 2006a). As a result, the sum of aerosol properties calculated from individual aerosol component emissions does not necessarily add-up to the aerosol properties considering the full mix of aerosol and aerosol precursor emission changes. To investigate these deviation from additivity we conducted two more experiments: one in which the $\mathrm{SO}_{2}$ emission are kept at there 2000 levels and carbonaceous (BC and POM) emission decrease according to MFR 2030 (SULFUR:2000) and one in which the carbonaceous emissions are kept at there 2000 levels and $\mathrm{SO}_{2}$ emission decrease according to the MFR 2030 scenario (CARBON:2000). The global budgets for the single experiments are summarized in Table 5. To exclude any impacts from different oxidant concentrations we use the 2000:CHEM:2030:MFR experiment as reference.

In idealized sensitivity studies Stier et al. (2006a) performed experiments using the ECHAM5-HAM model, for the extreme case of the omission of anthropogenic $\mathrm{SO}_{2}$ and $\mathrm{BC}$ emissions. They found deviation from additivity of the AOD reaching up to $15 \%$ in anthropogenic sources regions. However, as already mentioned the aerosol system is nonlinear. Here, we therefore extend the analysis by Stier et al. (2006a) of the additivity using more realistic future emission scenarios. We focus thereby on the total aerosol TOA RF.

Figure 4 shows the additivity of the TOA clear sky RF. Additivity is thereby defined similar to Stier et al. (2006a) as:

$a=(\triangle \mathrm{MFR}: 2030)$

$-(\triangle$ SULFUR : $2000+\triangle \mathrm{CARBON}: 2000)$

with $\triangle X=X-\mathrm{REF}$ and $X \in$ (MFR:2030, SULFUR:2000, CARBON:2000); REF is the reference experiment 2000:CHEM:2030:MFR. 
Negative deviations are simulated over the anthropogenic source regions reaching up to $-0.6 \mathrm{~W} / \mathrm{m}^{2}$ over Asia. This is about $10 \%$ of the positive TOA RF (2030-2000) simulated in the MFR:2030 experiment. A negative deviation from additivity implies that the positive TOA RF caused by decreasing aerosol emissions is higher in the sum of the individual experiments ( $\triangle$ SULFUR:2000+ $\triangle$ CARBON:2000) than in the combined experiment ( $\triangle$ MFR:2030). This is explained by the simulated deviations from additivity for the AOD, for which we simulate positive deviations from additivity over the anthropogenic source regions reaching up to $12 \%$ over Asia (not shown), implying that the AOD is more efficiently reduced in the sum of the individual experiments and thus leads to a higher positive TOA RF.

Such a positive deviation from additivity for the AOD has been shown before in a similar sensitivity study already mentioned above (Stier et al., 2006a). The changes in the AOD, which is dominated over the anthropogenic source regions by aerosols in the accumulation hydrophilic mode, is a result of the interdependence of sulfate and carbonaceous emission to form aerosols of the accumulation size mode range. Gas-phase $\mathrm{SO}_{4}$ condenses on the surface of primary emitted carbonaceous particles, so that they grow into the accumulation size mode. Consequently, changes of accumulation size mode particles depends non-linearly on the mixture of gas-phase $\mathrm{SO}_{4}$ and the number of primary carbonaceous seeds available for condensation and subsequent growth into the accumulation size range. As a result the aerosol number concentrations of the accumulation hydrophilic mode is more efficiently reduced in sum of the two individual experiments compared to the combined experiment. Thus the deviation from additivity is positive (up to $6 \%$ in our study over Asia) and explains the positive deviations of the AOD and the resulting negative deviation from additivity for the positive TOA RF.

\section{Discussion and conclusions}

This study used the global ECHAM5-HAM (Roeckner et al., 2003) atmospheric general circulation model to assess possible impacts of future aerosol and aerosol precursor emissions on the Earth's radiation budget. The ECHAM5-HAM model includes a microphysical aerosol-cloud model (Stier et al., 2005; Lohmann et al., 2007), allowing to account for both, the direct and indirect aerosol effects. We compared two different future aerosol and aerosol precursor emission scenarios for the year 2030 recently developed by the International Institute for Applied System Analysis (IIASA, Cofala et al., 2007): "current legislation" (CLE 2030) and "maximum feasible reduction" (MFR 2030). The comparison is done in terms of radiative forcing (RF) at the top-of-the-atmosphere (TOA) compared to present-day conditions, i.e. the perturbation of the present-day total anthropogenic aerosol RF. Besides the two contrasting scenarios we performed simulations using sectoral and regional combinations of these two.

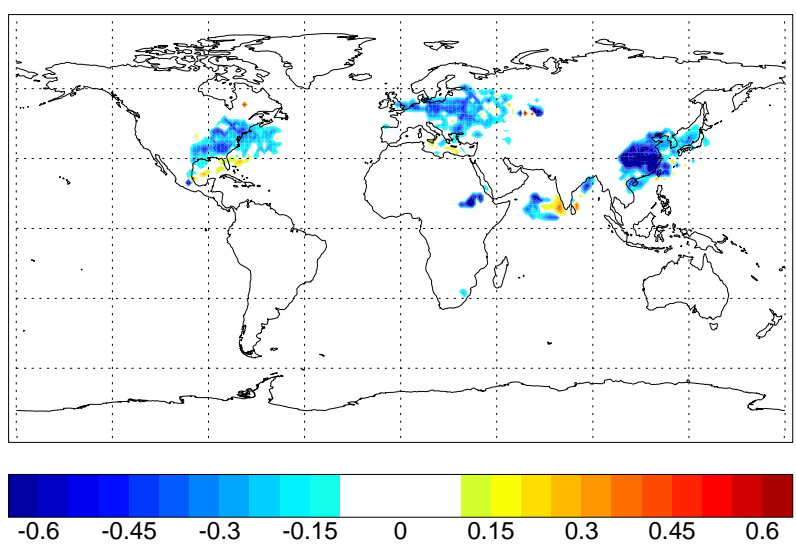

Fig. 4. The deviation from additivity for TOA clear sky SW aerosol $\mathrm{RF}$ in $\left[\mathrm{W} / \mathrm{m}^{2}\right]$ defined as the difference in the response (compared to the reference experiments) between the sum of the experiments in which carbonaceous and $\mathrm{SO}_{2}$ are changed individually ( $\triangle$ SULFUR:2000+ $\triangle$ CARBON:2000) and the experiment in which all emissions are changed at the same time ( $\triangle$ MFR:2030).

Control of aerosol and aerosol precursor emissions to a maximum feasible potential decreases anthropogenic $\mathrm{SO}_{2}$, $\mathrm{BC}$ and POM emissions worldwide and introduces a positive TOA RF (2030-2000) globally. The global annual mean TOA RF amounts to $+1.13 \mathrm{~W} / \mathrm{m}^{2}$ compared to presentday conditions. This is about half of the negative TOA $\mathrm{RF}$ we simulate between pre-industrial and present day $\left(-2.00 \mathrm{~W} / \mathrm{m}^{2}\right)$, clearly showing the large potential influence of reducing anthropogenic aerosol and aerosol precursor emission by air pollution mitigation in the future. Positive future TOA RF are largest over Asia, reflecting large present-day aerosol emissions and thus strong mitigation potentials in rapidly developing countries.

In contrast, current legislation for aerosol and aerosol precursor emissions leads to a decrease of $\mathrm{SO}_{2}$ emissions over Europe by 2030, whereas emissions mainly over Asia will continue to increase. Carbonaceous (BC and POM) emission will decrease worldwide. Overall, this leads to a very small global annual mean positive total aerosol TOA $\mathrm{RF}$ of $+0.02 \mathrm{~W} / \mathrm{m}^{2}$ compared to present-day conditions. Thereby, negative TOA RF prevail over Asia (e.g. South Asia $-1.10 \mathrm{~W} / \mathrm{m}^{2}$ ) while they are positive over Europe (e.g. Eastern Europe $+1.50 \mathrm{~W} / \mathrm{m}^{2}$ ).

Implementation of all feasible control technologies for aerosol and aerosol precursor emissions only in Europe (the rest of the world stays with its current legislation) leads to a negligible global annual mean future TOA RF of $-0.001 \mathrm{~W} / \mathrm{m}^{2}$. In contrast, if Asia reduces aerosol and aerosol precursor emissions according to MFR 2030 the TOA RF amounts to $+0.32 \mathrm{~W} / \mathrm{m}^{2}$. Other regions will benefit in terms of air pollution from an application of MFR 2030 in Europe or Asia due to reduced transport of aerosols out of these regions.

As mitigation policies focus on specific economic source sectors (like road traffic or power generation) we conducted 
additional experiments focusing on the potential of reducing aerosol and aerosol precursor emissions in the Powerplant and Industry sector (which are dominated by $\mathrm{SO}_{2}$ emissions) or the combined Transport and Domestic sectors (which are dominated by carbonaceous emissions). Reducing aerosol and aerosol precursor emissions in the Industry and Powerplant sector according to MFR 2030 while the other sectors stay with CLE 2030 leads to a future TOA RF (20302000) of $+0.76 \mathrm{~W} / \mathrm{m}^{2}$ caused mainly by strongly decreasing $\mathrm{SO}_{2}$ emissions globally. In contrast, reducing aerosol and aerosol precursor emissions in the Domestic and Transport sector according to MFR mainly leads to a strong reduction of carbonaceous emissions while global annual mean $\mathrm{SO}_{2}$ still increase, leading to a TOA RF of $+0.18 \mathrm{~W} / \mathrm{m}^{2}$, with a reduced atmospheric absorption due to less absorbing aerosols present in the same magnitude $\left(-0.14 \mathrm{~W} / \mathrm{m}^{2}\right)$.

To further improve the understanding of the implications of air pollution policies for climate change and the effectiveness of climate change mitigation best advise could be given by calculating the RF for each individual sector or as it has been traditionally done for specific aerosol compounds (e.g. Forster et al., 2007, Koch et al., 2007, Unger et al., 2008). Such an approach requires that the aerosol system is additive, i.e. the sum of the RF simulated for the change of each sector or aerosol compound individually is identical to the RF taking into account the change of the full mix of aerosols present. Deviations from additivity can be expected as the sectors vary significantly in terms of their mix of aerosol and aerosol precursor emissions and thus in terms of their microphysical properties. We tested this for the extreme case of a maximum abatement of either $\mathrm{SO}_{2}$ emissions or carbonaceous emissions in the future. Compared to an experiment considering the abatement of both $\left(\mathrm{SO}_{2}\right.$ and carbonaceous emissions) we found non negligible deviations from additivity for the clear-sky $\mathrm{RF}$ reaching up to $-0.6 \mathrm{~W} / \mathrm{m}^{2}$ in the anthropogenic source regions, which is about $10 \%$ of the TOA RF (2030-2000) simulated in the MFR 2030 experiment. This indicates, that the impact of future air pollution mitigation strategies on RF can only be assessed correctly by taking into to account the full range of aerosol and aerosol precursor emissions changes as expected for the future.

However, the assessment of the RF as done in this study has some limitations as they are not fully consistent in terms of oxidant concentrations used in the sulfur chemistry model to simulate the production of $\mathrm{SO}_{4}$. Oxidant concentrations will change in the future as a result of air pollution mitigation. Due to computational constraints ECHAM5-HAM uses prescribed oxidant concentrations as simulated within the TM3 chemistry model. Oxidant concentrations were available for the year 2000 and the two scenarios CLE 2030 and MFR 2030 (Dentener et al., 2006a). However, for the sectoral and regional experiments no corresponding TM3 study was conducted, so that we kept oxidant concentrations at the level of the year 2000. We have performed two more sensitivity studies in which CLE and MFR 2030 aerosol and aerosol precursor emissions are applied in combination with 2000 oxidant concentrations instead of using the corresponding scenario calculations. As a result we find a decrease in $\mathrm{SO}_{4}$ burden over South Asia (-5\%) in case of CLE, due to a less efficient gas-phase production of $\mathrm{SO}_{4}$ when applying 2000 oxidant concentrations. For MFR we simulate an increase over Asia $(+2 \%)$ caused by a more efficient gas-phase production when applying 2000 oxidant concentrations. For both scenarios changing oxidant concentrations in the future will dampen the emissions trends mainly over Asia, i.e. for CLE 2030 increasing emissions are combined with less efficient $\mathrm{SO}_{4}$ production and for MFR 2030 decreasing aerosol emissions are combined with more efficient $\mathrm{SO}_{4}$ production. Overall, we conclude that the influence of air pollution mitigation strategies for oxidant concentrations in a realistic range between present day and 2030 will not significantly alter the global annual mean $\mathrm{SO}_{4}$ production and thus the influence on TOA RF is rather small. A recently developed new version of the ECHAM5-HAM model including the full MOZART chemistry scheme as described in Pozzoli et al. (2007) will allow more consistent simulations in the future.

We focused in our study on anthropogenic aerosol and aerosol-precursor emissions and neglected possible changes in natural emissions. However, natural aerosol emissions like dust emission (Tegen et al., 2004; Mahowald et al., 2006b), DMS emissions (Kloster et al., 2007) or sea salt emissions (Mahowald et al., 2006a) are likely to change in the future due to changes in the climate state. However, the magnitude and even the sign of changes expected in a warmer future global climate are highly uncertain, making it difficult to assess the extent to which natural emissions will strengthen or weaken the TOA RF caused by changes in anthropogenic aerosol emissions. In addition we neglected any natural or anthropogenic changes in biomass burning aerosol emissions in the future, whereas a recent study suggested that carbonaceous biomass burning emissions are likely to decrease in the future (Streets et al., 2004).

Finally, we want to stress that measures aiming at improving future air quality will have implication on climate change mitigation strategies aimed at maintaining global warming below a specific threshold (Brasseur et al., 2005; Shindell et al., 2007). When more stringent air pollution abatements are implemented worldwide, utilizing the presently available most advanced control technologies, the present-day negative total aerosol TOA RF will be strongly reduced (by 50\%) by 2030 . As a consequence climate change thereafter will be controlled to a larger extent by changes in greenhouse gas emissions. Climate change mitigation strategies should take into account climate impacts caused by improved air quality and changes in greenhouse gas emissions, focusing on a simultaneous reduction of air pollution and greenhouse gas emission. 


\section{Appendix A}

Table A1. Regional Budgets for the single experiments. Regions are defined as shown in Fig. A4. The source of $\mathrm{SO}_{2}$ comprises primary emissions as well as $\mathrm{SO}_{2}$ derived from DMS oxidation. Absolute values are given for the 2000 experiment. For the others experiments percentage differences are given with respect to the 2000 simulations, i.e. (2000-PI) in case of the PI experiment and EXP-2000 for EXP $\in$ (MFR:2030, CLE:2030, MFR:2030:IP, MFR:2030:DT, MFR:2030:Europe, MFR:2030:Asia).

\begin{tabular}{|c|c|c|c|c|c|c|c|c|}
\hline & & CAN & USA & $\begin{array}{l}\text { Central } \\
\text { America }\end{array}$ & $\begin{array}{c}\text { South } \\
\text { America }\end{array}$ & $\begin{array}{c}\text { Northern } \\
\text { Africa }\end{array}$ & $\begin{array}{c}\text { Western } \\
\text { Africa }\end{array}$ & $\begin{array}{c}\text { Eastern } \\
\text { Africa }\end{array}$ \\
\hline \multicolumn{9}{|l|}{ Experiment 2000} \\
\hline Source $\mathrm{SO}_{2}$ & {$[\mathrm{Gg}(\mathrm{S}) / \mathrm{yr}]$} & 920.7 & 8464.0 & 2033.9 & 4479.2 & 810.1 & 781.6 & 438.5 \\
\hline Burden $\mathrm{SO}_{4}$ & {$[\mathrm{Gg}(\mathrm{S})]$} & 8.1 & 24.0 & 10.4 & 27.7 & 28.4 & 35.7 & 24.7 \\
\hline Emission BC & {$[\mathrm{Gg} / \mathrm{yr}]$} & 41.0 & 309.0 & 233.6 & 975.1 & 37.2 & 930.2 & 412.0 \\
\hline Burden BC & {$[\mathrm{Gg}]$} & 0.5 & 2.0 & 1.3 & 11.4 & 1.8 & 15.7 & 4.5 \\
\hline Emission POM & {$[\mathrm{Gg} / \mathrm{yr}]$} & 954.7 & 2720.7 & 2400.1 & 15618.2 & 198.5 & 10984.6 & 4439.3 \\
\hline Burden POM & {$[\mathrm{Gg}]$} & 7.4 & 21.2 & 12.2 & 153.7 & 11.9 & 160.7 & 39.9 \\
\hline AOD & [ ] & 3.0 & 11.2 & 16.7 & 13.1 & 19.3 & 31.8 & 21.1 \\
\hline \multicolumn{9}{|l|}{ Experiment PI : 2000-PI } \\
\hline Source $\mathrm{SO}_{2}$ & {$[\%]$} & 93.4 & 97.9 & 72.7 & 36.0 & 98.9 & 71.8 & 60.0 \\
\hline Burden $\mathrm{SO}_{4}$ & {$[\%]$} & 66.9 & 82.9 & 66.5 & 34.7 & 56.7 & 58.1 & 68.4 \\
\hline Emission BC & {$[\%]$} & 6.2 & 94.7 & 94.5 & 75.7 & 82.5 & 71.7 & 68.6 \\
\hline Burden BC & {$[\%]$} & 43.3 & 91.9 & 91.9 & 69.7 & 81.9 & 70.8 & 73.7 \\
\hline Emission POM & {$[\%]$} & -62.5 & 50.0 & 69.5 & 41.5 & 67.1 & 55.4 & 58.2 \\
\hline Burden POM & {$[\%]$} & -15.1 & 48.2 & 68.1 & 47.1 & 59.0 & 61.2 & 59.5 \\
\hline AOD & {$[\%]$} & 67.8 & 78.7 & 50.4 & 30.9 & 24.2 & 30.7 & 41.9 \\
\hline TOA forcing Total sky & {$\left[\mathrm{W} / \mathrm{m}^{2}\right]$} & -1.387 & -2.732 & -3.207 & -1.814 & -0.615 & -0.677 & -2.289 \\
\hline TOA forcing Clear sky & {$\left[\mathrm{W} / \mathrm{m}^{2}\right]$} & -0.646 & -1.883 & -1.608 & -0.569 & -0.206 & -0.819 & -1.021 \\
\hline \multicolumn{9}{|c|}{ Experiment MFR:2030: MFR:2030-2000 } \\
\hline Source $\mathrm{SO}_{2}$ & {$[\%]$} & -72.3 & -82.5 & -59.6 & -18.0 & -79.8 & -18.8 & -18.7 \\
\hline Burden $\mathrm{SO}_{4}$ & {$[\%]$} & -52.2 & -67.3 & -52.2 & -18.3 & -45.7 & -39.3 & -52.4 \\
\hline Emission BC & {$[\%]$} & -54.2 & -51.7 & -40.8 & -19.8 & -23.9 & -4.0 & -5.1 \\
\hline Burden BC & {$[\%]$} & -31.3 & -44.7 & -37.7 & -10.6 & -33.0 & -6.0 & -16.4 \\
\hline Emission POM & {$[\%]$} & -3.6 & -9.1 & -15.6 & -3.9 & -19.0 & -2.5 & -3.9 \\
\hline Burden POM & {$[\%]$} & -3.8 & -8.0 & -13.0 & -2.7 & -11.1 & -3.3 & -8.5 \\
\hline AOD & {$[\%]$} & -55.6 & -62.5 & -37.2 & -11.1 & -19.1 & -14.0 & -29.2 \\
\hline TOA forcing Total sky & {$\left[\mathrm{W} / \mathrm{m}^{2}\right]$} & 1.109 & 1.640 & 1.726 & 0.798 & 0.525 & 0.421 & 1.037 \\
\hline \multirow[t]{2}{*}{ TOA forcing Clear sky } & {$\left[\mathrm{W} / \mathrm{m}^{2}\right]$} & 0.517 & 1.477 & 1.229 & 0.260 & 0.320 & 0.588 & 0.878 \\
\hline & & $\begin{array}{l}\text { Southern } \\
\text { Africa }\end{array}$ & $\begin{array}{l}\text { Europe } \\
\text { OECD }\end{array}$ & $\begin{array}{l}\text { Europe } \\
\text { Eastern }\end{array}$ & $\begin{array}{c}\text { Europe } \\
\text { Reg. Exp. }\end{array}$ & $\begin{array}{l}\text { USSR } \\
\text { former }\end{array}$ & Middle East & $\begin{array}{l}\text { South } \\
\text { Asia }\end{array}$ \\
\hline \multicolumn{9}{|l|}{ Experiment 2000} \\
\hline Source $\mathrm{SO}_{2}$ & {$[\mathrm{Gg}(\mathrm{S}) / \mathrm{yr}]$} & 1730.2 & 5702.2 & 3020.2 & 12991.2 & 5590.4 & 3050.8 & 3694.2 \\
\hline Burden $\mathrm{SO}_{4}$ & {$[\mathrm{Gg}(\mathrm{S})]$} & 13.0 & 9.9 & 4.2 & 32.5 & 32.2 & 31.0 & 23.8 \\
\hline Emission BC & {$[\mathrm{Gg} / \mathrm{yr}]$} & 706.9 & 309.3 & 98.9 & 590.9 & 275.3 & 99.4 & 780.3 \\
\hline Burden BC & {$[\mathrm{Gg}]$} & 6.6 & 1.2 & 0.5 & 3.4 & 2.7 & 2.4 & 7.0 \\
\hline Emission POM & {$[\mathrm{Gg} / \mathrm{yr}]$} & 7520.1 & 910.0 & 414.5 & 2282.1 & 3213.9 & 346.7 & 3661.5 \\
\hline Burden POM & {$[\mathrm{Gg}]$} & 67.3 & 4.6 & 2.1 & 16.5 & 24.5 & 13.6 & 33.4 \\
\hline AOD & [ ] & 12.7 & 14.0 & 20.1 & 14.8 & 7.5 & 16.1 & 20.6 \\
\hline
\end{tabular}


Table A1. Continued.

\begin{tabular}{|c|c|c|c|c|c|c|c|c|}
\hline & & $\begin{array}{c}\text { Southern } \\
\text { Africa }\end{array}$ & $\begin{array}{l}\text { Europe } \\
\text { OECD }\end{array}$ & $\begin{array}{l}\text { Europe } \\
\text { Eastern }\end{array}$ & $\begin{array}{c}\text { Europe } \\
\text { Reg. Exp. }\end{array}$ & $\begin{array}{l}\text { USSR } \\
\text { former }\end{array}$ & Middle East & $\begin{array}{l}\text { South } \\
\text { Asia }\end{array}$ \\
\hline \multicolumn{9}{|l|}{ Experiment PI: 2000-PI } \\
\hline Source $\mathrm{SO}_{2}$ & {$[\%]$} & 87.4 & 58.3 & 99.9 & 80.6 & 96.8 & 81.7 & 98.7 \\
\hline Burden $\mathrm{SO}_{4}$ & {$[\%]$} & 52.9 & 69.9 & 77.0 & 73.9 & 76.7 & 103.1 & 82.9 \\
\hline Emission $\mathrm{BC}$ & {$[\%]$} & 66.9 & 96.4 & 93.5 & 93.6 & 59.4 & 12.0 & 91.1 \\
\hline Burden BC & {$[\%]$} & 67.1 & 93.5 & 92.6 & 90.7 & 71.8 & 29.5 & 90.4 \\
\hline Emission POM & {$[\%]$} & 57.2 & 52.1 & 67.6 & 49.4 & -0.9 & 5.0 & 68.6 \\
\hline Burden POM & {$[\%]$} & 59.4 & 52.5 & 59.3 & 50.3 & 19.3 & 23.0 & 67.4 \\
\hline AOD & {$[\%]$} & 47.2 & 53.2 & 71.4 & 60.6 & 61.5 & 38.0 & 52.6 \\
\hline TOA forcing Total sky & {$\left[\mathrm{W} / \mathrm{m}^{2}\right]$} & -2.371 & -5.620 & -5.695 & -52.97 & -2.555 & -1.381 & -2.461 \\
\hline TOA forcing Clear sky & {$\left[\mathrm{W} / \mathrm{m}^{2}\right]$} & -0.863 & -1.770 & -3.076 & -2.194 & -1.223 & -1.089 & -1.182 \\
\hline \multicolumn{9}{|c|}{ Experiment MFR:2030: MFR:2030-2000 } \\
\hline Source $\mathrm{SO}_{2}$ & {$[\%]$} & -63.2 & -48.2 & -89.9 & -68.5 & -82.8 & -75.6 & -56.1 \\
\hline Burden $\mathrm{SO}_{4}$ & {$[\%]$} & -33.6 & -56.0 & -63.9 & -60.4 & -63.1 & -87.2 & -59.8 \\
\hline Emission BC & {$[\%]$} & -5.3 & -70.3 & -68.5 & -61.6 & -29.6 & -8.9 & -42.6 \\
\hline Burden BC & {$[\%]$} & -5.4 & -62.7 & -62.4 & -54.9 & -34.5 & -15.4 & -42.7 \\
\hline Emission POM & {$[\%]$} & -2.3 & -25.2 & -35.0 & -26.9 & -8.9 & -3.7 & -46.0 \\
\hline Burden POM & {$[\%]$} & -2.6 & -19.4 & -26.0 & -19.0 & -10.4 & -7.6 & -42.6 \\
\hline AOD & {$[\%]$} & -20.7 & -41.6 & -58.6 & -48.9 & -51.5 & -31.9 & -36.0 \\
\hline TOA forcing Total sky & {$\left[\mathrm{W} / \mathrm{m}^{2}\right]$} & 1.126 & 2.850 & 3.269 & 2.932 & 1.717 & 1.080 & 1.267 \\
\hline \multirow[t]{2}{*}{ TOA forcing Clear sky } & {$\left[\mathrm{W} / \mathrm{m}^{2}\right]$} & 0.519 & 1.366 & 2.475 & 1.739 & 1.007 & 1.030 & 0.991 \\
\hline & & $\begin{array}{l}\text { East } \\
\text { Asia }\end{array}$ & $\begin{array}{c}\text { South East } \\
\text { Asia }\end{array}$ & $\begin{array}{c}\text { Asia } \\
\text { Reg. Exp. }\end{array}$ & Japan & Greenland & Oceania & Global \\
\hline \multicolumn{9}{|l|}{ Experiment 2000} \\
\hline Source $\mathrm{SO}_{2}$ & {$[\mathrm{Gg}(\mathrm{S}) / \mathrm{yr}]$} & 15161.6 & 1931.0 & 23256.9 & 972.9 & 3.2 & 1253.0 & 95994.8 \\
\hline Burden $\mathrm{SO}_{4}$ & {$[\mathrm{Gg}(\mathrm{S})]$} & 36.3 & 13.0 & 78.8 & 1.8 & 1.0 & 10.0 & 857.8 \\
\hline Emission BC & {$[\mathrm{Gg} / \mathrm{yr}]$} & 1912.3 & 566.4 & 3223.0 & 55.6 & 0.0 & 228.5 & 8111.6 \\
\hline Burden BC & {$[\mathrm{Gg}]$} & 11.2 & 3.6 & 22.6 & 0.3 & 0.0 & 2.0 & 123.5 \\
\hline Emission POM & {$[\mathrm{Gg} / \mathrm{yr}]$} & 6387.8 & 5086.0 & 15508.9 & 132.3 & 2.0 & 3187.8 & 69140.5 \\
\hline Burden POM & {$[\mathrm{Gg}]$} & 45.2 & 26.2 & 111.6 & 1.3 & 0.2 & 25.2 & 1075.0 \\
\hline AOD & [ ] & 19.2 & 15.5 & 19.1 & 22.3 & 0.5 & 11.1 & 16.2 \\
\hline \multicolumn{9}{|l|}{ Experiment PI: 2000-PI } \\
\hline Source $\mathrm{SO}_{2}$ & {$[\%]$} & 95.9 & 83.8 & 83.2 & 42.4 & 13.6 & 72.7 & 59.8 \\
\hline Burden $\mathrm{SO}_{4}$ & {$[\%]$} & 86.2 & 62.1 & 74.3 & 72.2 & 56.6 & 35.8 & 53.3 \\
\hline Emission BC & {$[\%]$} & 94.1 & 83.9 & 91.5 & 89.2 & 100.0 & 74.2 & 82.7 \\
\hline Burden BC & {$[\%]$} & 91.4 & 83.7 & 89.4 & 89.9 & 71.3 & 75.6 & 78.0 \\
\hline Emission POM & {$[\%]$} & 74.7 & 53.1 & 65.6 & 35.4 & 0.4 & 52.0 & 50.9 \\
\hline Burden POM & {$[\%]$} & 69.9 & 58.5 & 65.9 & 56.6 & 23.0 & 56.9 & 56.7 \\
\hline $\mathrm{AOD}$ & {$[\%]$} & 81.7 & 55.4 & 63.6 & 62.9 & 48.1 & 17.7 & 25.1 \\
\hline TOA forcing Total sky & {$\left[\mathrm{W} / \mathrm{m}^{2}\right]$} & -4.187 & -3.910 & -3.633 & -5.954 & -0.153 & -0.951 & -2.047 \\
\hline TOA forcing Clear sky & {$\left[\mathrm{W} / \mathrm{m}^{2}\right]$} & -2.342 & -1.481 & -1.837 & -2.698 & -0.081 & -0.272 & -0.824 \\
\hline \multicolumn{9}{|c|}{ Experiment MFR:2030: MFR:2030-2000 } \\
\hline Source $\mathrm{SO}_{2}$ & {$[\%]$} & -73.0 & -45.5 & -59.5 & -27.5 & -4.1 & -57.0 & -44.5 \\
\hline Burden $\mathrm{SO}_{4}$ & {$[\%]$} & -66.9 & -42.2 & -54.6 & -54.4 & -42.1 & -24.2 & -38.7 \\
\hline Emission BC & {$[\%]$} & -37.6 & -16.8 & -34.2 & -83.7 & -37.7 & -7.5 & -27.8 \\
\hline Burden BC & {$[\%]$} & -33.6 & -20.8 & -33.5 & -44.2 & -24.4 & -5.1 & -17.2 \\
\hline Emission POM & {$[\%]$} & -51.1 & -16.1 & -37.2 & -41.2 & 0.0 & -0.6 & -12.7 \\
\hline Burden POM & {$[\%]$} & -40.3 & -19.6 & -34.8 & -38.2 & -9.5 & -0.8 & -9.5 \\
\hline AOD & {$[\%]$} & -60.7 & -35.7 & -45.1 & -45.9 & -36.2 & -9.4 & -16.5 \\
\hline TOA forcing Total sky & {$\left[\mathrm{W} / \mathrm{m}^{2}\right]$} & 1.702 & 1.524 & 1.479 & 3.431 & 0.106 & 0.293 & 1.132 \\
\hline TOA forcing Clear sky & {$\left[\mathrm{W} / \mathrm{m}^{2}\right]$} & 1.844 & 1.033 & 1.396 & 2.029 & 0.068 & 0.220 & 0.580 \\
\hline
\end{tabular}


Table A1. Continued.

\begin{tabular}{|c|c|c|c|c|c|c|c|c|}
\hline & & CAN & USA & $\begin{array}{l}\text { Central } \\
\text { America }\end{array}$ & $\begin{array}{c}\text { South } \\
\text { America }\end{array}$ & $\begin{array}{c}\text { Northern } \\
\text { Africa }\end{array}$ & $\begin{array}{c}\text { Western } \\
\text { Africa }\end{array}$ & $\begin{array}{c}\text { Eastern } \\
\text { Africa }\end{array}$ \\
\hline \multicolumn{9}{|c|}{ Experiment CLE:2030: CLE:2030-2000 } \\
\hline Source $\mathrm{SO}_{2}$ & {$[\%]$} & 0.5 & -5.8 & -37.2 & 8.6 & 16.5 & 11.0 & 11.7 \\
\hline Burden $\mathrm{SO}_{4}$ & {$[\%]$} & 6.0 & -1.3 & -7.8 & 8.0 & -11.7 & 0.0 & 6.3 \\
\hline Emission BC & {$[\%]$} & -28.7 & -27.6 & -26.4 & -10.3 & 31.4 & 0.6 & -1.1 \\
\hline Burden BC & {$[\%]$} & -17.7 & -24.4 & -22.6 & -5.9 & -11.7 & -1.2 & -4.6 \\
\hline Emission POM & {$[\%]$} & -0.8 & -2.3 & -13.5 & -3.0 & -1.1 & -1.3 & -2.0 \\
\hline Burden POM & {$[\%]$} & -2.1 & -3.8 & -10.9 & -2.1 & -5.4 & -1.9 & -5.1 \\
\hline AOD & {$[\%]$} & -1.8 & -4.4 & -8.0 & 3.1 & -5.3 & 0.1 & 2.3 \\
\hline TOA forcing Total sky & {$\left[\mathrm{W} / \mathrm{m}^{2}\right]$} & 0.085 & 0.070 & 0.652 & 0.382 & 0.099 & -0.206 & -0.208 \\
\hline TOA forcing Clear sky & {$\left[\mathrm{W} / \mathrm{m}^{2}\right]$} & 0.014 & 0.039 & 0.199 & -0.109 & 0.059 & -0.089 & -0.214 \\
\hline \multicolumn{9}{|c|}{ Experiment MFR:2030:IP: MFR:2030:IP-2000 } \\
\hline Source $\mathrm{SO}_{2}$ & {$[\%]$} & -64.2 & -79.3 & -55.2 & -15.3 & -57.0 & -3.0 & -2.0 \\
\hline Burden $\mathrm{SO}_{4}$ & {$[\%]$} & -45.1 & -60.4 & -42.9 & -11.2 & -38.0 & -30.3 & -42.7 \\
\hline Emission BC & {$[\%]$} & -30.6 & -30.2 & -28.1 & -13.1 & 27.2 & -0.6 & -3.7 \\
\hline Burden BC & {$[\%]$} & -16.6 & -25.6 & -23.4 & -7.4 & -13.2 & -2.5 & -7.6 \\
\hline Emission POM & {$[\%]$} & -0.8 & -2.5 & -13.8 & -3.3 & -2.1 & -1.5 & -2.5 \\
\hline Burden POM & {$[\%]$} & -1.3 & -3.2 & -10.5 & -2.2 & -5.4 & -2.0 & -5.7 \\
\hline AOD & {$[\%]$} & -49.5 & -56.0 & -30.0 & -6.8 & -15.8 & -10.7 & -23.9 \\
\hline TOA forcing Total sky & {$\left[\mathrm{W} / \mathrm{m}^{2}\right]$} & 0.848 & 1.279 & 1.543 & 0.572 & 0.441 & 0.198 & 0.628 \\
\hline TOA forcing Clear sky & {$\left[\mathrm{W} / \mathrm{m}^{2}\right]$} & 0.442 & 1.335 & 0.998 & 0.158 & 0.331 & 0.468 & 0.746 \\
\hline \multicolumn{9}{|c|}{ Experiment MFR:2030:DT: MFR:2030:DT-2000 } \\
\hline Source $\mathrm{SO}_{2}$ & {$[\%]$} & -7.7 & -9.0 & -41.6 & 5.8 & -6.3 & -4.9 & -5.0 \\
\hline Burden $\mathrm{SO}_{4}$ & {$[\%]$} & -0.2 & -11.0 & -18.6 & 1.2 & -18.1 & -7.7 & -2.6 \\
\hline Emission BC & {$[\%]$} & -52.3 & -49.0 & -39.0 & -17.0 & -19.8 & -2.8 & -2.6 \\
\hline Burden BC & {$[\%]$} & -31.5 & -43.1 & -36.4 & -9.1 & -31.3 & -4.8 & -13.1 \\
\hline Emission POM & {$[\%]$} & -3.5 & -8.9 & -15.4 & -3.6 & -17.9 & -2.3 & -3.4 \\
\hline Burden 0C & {$[\%]$} & -4.5 & -8.3 & -13.3 & -2.5 & -10.9 & -3.1 & -7.6 \\
\hline AOD & {$[\%]$} & -9.4 & -13.9 & -16.9 & -1.1 & -9.8 & -3.9 & -3.1 \\
\hline TOA forcing Total sky & {$\left[\mathrm{W} / \mathrm{m}^{2}\right]$} & 0.217 & 0.385 & 0.862 & 0.523 & 0.189 & -0.068 & -0.090 \\
\hline \multirow[t]{2}{*}{ TOA forcing Clear sky } & {$\left[\mathrm{W} / \mathrm{m}^{2}\right]$} & 0.069 & 0.239 & 0.467 & -0.014 & 0.056 & 0.014 & -0.090 \\
\hline & & $\begin{array}{c}\text { Southern } \\
\text { Africa }\end{array}$ & $\begin{array}{l}\text { Europe } \\
\text { OECD }\end{array}$ & $\begin{array}{l}\text { Europe } \\
\text { Eastern }\end{array}$ & $\begin{array}{c}\text { Europe } \\
\text { Reg. Exp. }\end{array}$ & $\begin{array}{l}\text { USSR } \\
\text { former }\end{array}$ & Middle East & $\begin{array}{l}\text { South } \\
\text { Asia }\end{array}$ \\
\hline \multicolumn{9}{|c|}{ Experiment CLE:2030: CLE:2030-2000 } \\
\hline Source $\mathrm{SO}_{2}$ & {$[\%]$} & 0.1 & -33.5 & -61.1 & -42.6 & -42.5 & -46.9 & 192.2 \\
\hline Burden $\mathrm{SO}_{4}$ & {$[\%]$} & 11.4 & -18.6 & -30.3 & -23.3 & -19.8 & -21.7 & 87.4 \\
\hline Emission BC & {$[\%]$} & 2.2 & -55.4 & -51.8 & -33.5 & 14.6 & -3.9 & -12.5 \\
\hline Burden BC & {$[\%]$} & 0.9 & -45.9 & -42.3 & -29.6 & -5.2 & -4.9 & -10.2 \\
\hline Emission POM & {$[\%]$} & -0.9 & -16.7 & -26.5 & -9.4 & 2.1 & -2.1 & -34.0 \\
\hline Burden POM & {$[\%]$} & -1.6 & -12.2 & -17.1 & -8.0 & -2.5 & -4.3 & -30.5 \\
\hline AOD & {$[\%]$} & 6.3 & -18.7 & -31.6 & -23.4 & -22.2 & -9.7 & 48.6 \\
\hline TOA forcing Total sky & {$\left[\mathrm{W} / \mathrm{m}^{2}\right]$} & -0.277 & 1.009 & 1.504 & 1.027 & 0.486 & 0.328 & -1.094 \\
\hline TOA forcing Clear sky & {$\left[\mathrm{W} / \mathrm{m}^{2}\right]$} & -0.151 & 0.547 & 1.237 & 0.766 & 0.395 & 0.308 & -1.734 \\
\hline
\end{tabular}


Table A1. Continued.

\begin{tabular}{|c|c|c|c|c|c|c|c|c|}
\hline & & $\begin{array}{c}\text { Southern } \\
\text { Africa }\end{array}$ & $\begin{array}{l}\text { Europe } \\
\text { OECD }\end{array}$ & $\begin{array}{l}\text { Europe } \\
\text { Eastern }\end{array}$ & $\begin{array}{c}\text { Europe } \\
\text { Reg. Exp. }\end{array}$ & $\begin{array}{l}\text { USSR } \\
\text { former }\end{array}$ & Middle East & $\begin{array}{c}\text { South } \\
\text { Asia }\end{array}$ \\
\hline \multicolumn{9}{|c|}{ Experiment MFR:2030:IP: MFR:2030:IP-2000 } \\
\hline Source $\mathrm{SO}_{2}$ & {$[\%]$} & -56.2 & -44.0 & -86.6 & -63.6 & -78.3 & -72.4 & -40.3 \\
\hline Burden $\mathrm{SO}_{4}$ & {$[\%]$} & -25.8 & -47.4 & -57.6 & -53.2 & -57.2 & -78.2 & -48.0 \\
\hline Emission BC & {$[\%]$} & -0.2 & -56.6 & -53.5 & -37.6 & 7.4 & -4.2 & -21.1 \\
\hline Burden BC & {$[\%]$} & -0.7 & -46.4 & -43.4 & -31.3 & -7.0 & -5.8 & -18.1 \\
\hline Emission POM & {$[\%]$} & -1.3 & -16.9 & -27.0 & -10.9 & 1.2 & -2.2 & -36.2 \\
\hline Burden POM & {$[\%]$} & -1.8 & -11.4 & -16.8 & -7.5 & -1.8 & -4.3 & -32.6 \\
\hline AOD & {$[\%]$} & -15.9 & -34.6 & -52.5 & -42.7 & -46.8 & -28.5 & -27.8 \\
\hline TOA forcing Total sky & {$\left[\mathrm{W} / \mathrm{m}^{2}\right]$} & 0.816 & 1.980 & 2.614 & 2.088 & 1.334 & 0.989 & 1.079 \\
\hline TOA forcing Clear sky & {$\left[\mathrm{W} / \mathrm{m}^{2}\right]$} & 0.423 & 1.145 & 2.217 & 1.524 & 0.909 & 1.019 & 0.933 \\
\hline \multicolumn{9}{|c|}{ Experiment MFR:2030:DT: MFR:2030:DT-2000 } \\
\hline Source $\mathrm{SO}_{2}$ & {$[\%]$} & -6.9 & -37.7 & -64.5 & -47.6 & -46.9 & -50.1 & 176.4 \\
\hline Burden $\mathrm{SO}_{4}$ & {$[\%]$} & 3.8 & -25.6 & -35.0 & -29.1 & -24.5 & -30.3 & 59.7 \\
\hline Emission $\mathrm{BC}$ & {$[\%]$} & -3.0 & -69.1 & -66.8 & -57.5 & -22.4 & -8.5 & -34.0 \\
\hline Burden BC & {$[\%]$} & -3.7 & -61.9 & -60.8 & -52.6 & -31.3 & -14.4 & -34.8 \\
\hline Emission POM & {$[\%]$} & -1.8 & -25.0 & -34.5 & -25.4 & -7.9 & -3.5 & -43.8 \\
\hline Burden 0C & {$[\%]$} & -2.4 & -20.1 & -26.0 & -29.2 & -10.7 & -7.3 & -40.5 \\
\hline AOD & {$[\%]$} & 0.9 & -25.2 & -36.8 & -29.2 & -26.9 & -13.2 & 32.9 \\
\hline TOA forcing Total sky & {$\left[\mathrm{W} / \mathrm{m}^{2}\right]$} & -0.010 & 1.504 & 1.744 & 1.496 & 0.691 & 0.310 & -0.904 \\
\hline \multirow[t]{2}{*}{ TOA forcing Clear sky } & {$\left[\mathrm{W} / \mathrm{m}^{2}\right]$} & -0.050 & 0.743 & 1.404 & 0.950 & 0.474 & 0.310 & -1.468 \\
\hline & & $\begin{array}{l}\text { East } \\
\text { Asia }\end{array}$ & $\begin{array}{c}\text { South East } \\
\text { Asia }\end{array}$ & $\begin{array}{c}\text { Asia } \\
\text { Reg. Exp. }\end{array}$ & Japan & Greenland & Oceania & Global \\
\hline \multicolumn{9}{|c|}{ Experiment CLE:2030: CLE:2030-2000 } \\
\hline Source $\mathrm{SO}_{2}$ & {$[\%]$} & 2.9 & 98.4 & 37.4 & -15.6 & 12.0 & -27.1 & 3.7 \\
\hline Burden $\mathrm{SO}_{4}$ & {$[\%]$} & 7.7 & 42.4 & 41.5 & 1.6 & 11.6 & 0.6 & 9.1 \\
\hline Emission $\mathrm{BC}$ & {$[\%]$} & -17.6 & -4.1 & -13.9 & -57.3 & -10.0 & 1.7 & -11.1 \\
\hline Burden BC & {$[\%]$} & -16.3 & -9.4 & -13.3 & -23.2 & -15.0 & 1.3 & -7.9 \\
\hline Emission POM & {$[\%]$} & -35.8 & -10.9 & -26.6 & -16.8 & 0.2 & -0.1 & -8.1 \\
\hline Burden POM & {$[\%]$} & -29.2 & -14.6 & -25.5 & -24.1 & -9.5 & -0.3 & -6.4 \\
\hline AOD & {$[\%]$} & 1.9 & 26.8 & 19.8 & -2.4 & 6.7 & -2.2 & 2.3 \\
\hline TOA forcing Total sky & {$\left[\mathrm{W} / \mathrm{m}^{2}\right]$} & 0.053 & -0.266 & -0.292 & 0.454 & -0.002 & 0.054 & 0.016 \\
\hline TOA forcing Clear sky & {$\left[\mathrm{W} / \mathrm{m}^{2}\right]$} & -0.170 & -0.844 & -0.770 & -0.002 & -0.005 & 0.050 & -0.096 \\
\hline \multicolumn{9}{|c|}{ Experiment MFR:2030:IP: MFR:2030:IP-2000 } \\
\hline Source $\mathrm{SO}_{2}$ & {$[\%]$} & -65.0 & -31.6 & -51.1 & -22.2 & 12.0 & -53.6 & -35.5 \\
\hline Burden $\mathrm{SO}_{4}$ & {$[\%]$} & -59.0 & -32.1 & -45.2 & -46.4 & -34.7 & -18.3 & -30.6 \\
\hline Emission $\mathrm{BC}$ & {$[\%]$} & -29.0 & -5.1 & -22.8 & -64.8 & -10.0 & 1.5 & -16.2 \\
\hline Burden BC & {$[\%]$} & -24.3 & -9.8 & -19.7 & -31.7 & -12.4 & 1.9 & -10.4 \\
\hline Emission POM & {$[\%]$} & -39.2 & -11.1 & -28.5 & -18.2 & 0.2 & -0.1 & -8.8 \\
\hline Burden POM & {$[\%]$} & -30.5 & -13.9 & -26.4 & -25.3 & -6.1 & 0.1 & -6.6 \\
\hline AOD & {$[\%]$} & -52.8 & -27.5 & -37.4 & -37.9 & -30.4 & -7.0 & -12.8 \\
\hline TOA forcing Total sky & {$\left[\mathrm{W} / \mathrm{m}^{2}\right]$} & 1.293 & 1.047 & 1.164 & 1.896 & 0.095 & 0.341 & 0.761 \\
\hline TOA forcing Clear sky & {$\left[\mathrm{W} / \mathrm{m}^{2}\right]$} & 1.615 & 0.802 & 1.187 & 1.653 & 0.062 & 0.175 & 0.451 \\
\hline \multicolumn{9}{|c|}{ Experiment MFR:2030:DT: MFR:2030:DT-2000 } \\
\hline Source $\mathrm{SO}_{2}$ & {$[\%]$} & -5.1 & 84.6 & 29.0 & -20.8 & -4.1 & -30.5 & -5.3 \\
\hline Burden $\mathrm{SO}_{4}$ & {$[\%]$} & -2.7 & 29.0 & 25.8 & -7.5 & 6.7 & -4.0 & 0.8 \\
\hline Emission $\mathrm{BC}$ & {$[\%]$} & -26.2 & -15.8 & -25.3 & -76.1 & -37.7 & -7.3 & -22.6 \\
\hline Burden BC & {$[\%]$} & -25.1 & -19.5 & -26.7 & -35.5 & -25.3 & -5.3 & -17.5 \\
\hline Emission POM & {$[\%]$} & -47.7 & -16.0 & -35.2 & -39.8 & 0.0 & -0.6 & -12.0 \\
\hline Burden 0C & {$[\%]$} & -38.5 & -19.6 & -33.5 & -36.6 & -12.3 & -0.8 & -9.2 \\
\hline AOD & {$[\%]$} & -8.3 & 16.2 & 8.9 & -11.9 & 1.0 & -3.7 & -1.7 \\
\hline TOA forcing Total sky & {$\left[\mathrm{W} / \mathrm{m}^{2}\right]$} & 0.358 & 0.272 & 0.061 & 1.401 & 0.019 & 0.032 & 0.181 \\
\hline TOA forcing Clear sky & {$\left[\mathrm{W} / \mathrm{m}^{2}\right]$} & 0.099 & -0.571 & -0.492 & 0.402 & -0.008 & 0.077 & 0.027 \\
\hline
\end{tabular}


Table A1. Continued.

\begin{tabular}{|c|c|c|c|c|c|c|c|c|}
\hline & & CAN & USA & $\begin{array}{l}\text { Central } \\
\text { America }\end{array}$ & $\begin{array}{c}\text { South } \\
\text { America }\end{array}$ & $\begin{array}{c}\text { Northern } \\
\text { Africa }\end{array}$ & $\begin{array}{c}\text { Western } \\
\text { Africa }\end{array}$ & $\begin{array}{c}\text { Eastern } \\
\text { Africa }\end{array}$ \\
\hline \multicolumn{9}{|c|}{ Experiment MFR:2030:EUROPE: MFR:2030:EUROPE-2000 } \\
\hline Source $\mathrm{SO}_{2}$ & {$[\%]$} & 0.5 & -5.8 & -37.2 & 8.6 & 16.5 & 11.0 & 11.7 \\
\hline Burden $\mathrm{SO}_{4}$ & {$[\%]$} & 4.8 & -4.5 & -9.5 & 7.9 & -17.4 & -2.1 & 4.4 \\
\hline Emission BC & {$[\%]$} & -28.7 & -27.6 & -26.4 & -10.3 & 31.4 & 0.6 & -1.1 \\
\hline Burden BC & {$[\%]$} & -17.4 & -24.2 & -22.5 & -6.1 & -18.6 & -1.8 & -5.4 \\
\hline Emission POM & & -0.8 & -2.3 & -13.5 & -3.0 & -1.1 & -1.3 & -2.0 \\
\hline Burden POM & {$[\%]$} & -1.9 & -3.7 & -11.0 & -2.3 & -7.5 & -2.0 & -5.2 \\
\hline AOD & {$[\%]$} & -3.8 & -7.3 & -9.8 & 3.0 & -8.2 & 0.2 & 1.0 \\
\hline TOA forcing Total sky & {$\left[\mathrm{W} / \mathrm{m}^{2}\right]$} & 0.182 & 0.212 & 0.477 & 0.305 & 0.137 & -0.187 & -0.065 \\
\hline TOA forcing Clear sky & {$\left[\mathrm{W} / \mathrm{m}^{2}\right]$} & 0.030 & 0.109 & 0.255 & -0.105 & 0.099 & -0.084 & -0.191 \\
\hline \multicolumn{9}{|c|}{ Experiment MFR:2030:ASIA: MFR:2030:ASIA-2000 } \\
\hline Source $\mathrm{SO}_{2}$ & {$[\%]$} & 0.5 & -5.8 & -37.2 & 8.6 & 16.5 & 11.0 & 11.7 \\
\hline Burden $\mathrm{SO}_{4}$ & {$[\%]$} & -20.1 & -16.8 & -19.4 & 1.4 & -19.8 & -13.3 & -21.3 \\
\hline Emission BC & {$[\%]$} & -28.7 & -27.6 & -26.4 & -10.3 & 31.4 & 0.6 & -1.1 \\
\hline Burden BC & {$[\%]$} & -18.1 & -24.4 & -22.3 & -6.1 & -11.9 & -1.7 & -7.5 \\
\hline Emission POM & {$[\%]$} & -0.8 & -2.3 & -13.5 & -3.0 & -1.1 & -1.3 & -2.0 \\
\hline Burden POM & {$[\%]$} & -1.9 & -3.6 & -10.7 & -2.2 & -5.3 & -1.9 & -5.6 \\
\hline AOD & {$[\%]$} & -6.0 & -11.0 & -14.8 & 3.9 & -7.7 & -6.8 & -12.4 \\
\hline TOA forcing Total sky & {$\left[\mathrm{W} / \mathrm{m}^{2}\right]$} & 0.339 & 0.355 & 0.637 & 0.284 & 0.205 & 0.031 & 0.189 \\
\hline \multirow[t]{2}{*}{ TOA forcing Clear sky } & {$\left[\mathrm{W} / \mathrm{m}^{2}\right]$} & 0.140 & 0.277 & 0.404 & -0.051 & 0.135 & 0.189 & 0.340 \\
\hline & & $\begin{array}{c}\text { Southern } \\
\text { Africa }\end{array}$ & $\begin{array}{l}\text { Europe } \\
\text { OECD }\end{array}$ & $\begin{array}{l}\text { Europe } \\
\text { Eastern }\end{array}$ & $\begin{array}{c}\text { Europe } \\
\text { Reg. Exp. }\end{array}$ & $\begin{array}{l}\text { USSR } \\
\text { former }\end{array}$ & Middle East & $\begin{array}{l}\text { South } \\
\text { Asia }\end{array}$ \\
\hline \multicolumn{9}{|c|}{ Experiment MFR:2030:EUROPE: MFR:2030:EUROPE-2000 } \\
\hline Source $\mathrm{SO}_{2}$ & {$[\%]$} & 0.1 & -48.2 & -89.9 & -68.5 & -69.3 & -46.9 & 192.2 \\
\hline Burden $\mathrm{SO}_{4}$ & {$[\%]$} & 12.0 & -29.8 & -46.9 & -37.4 & -31.5 & -27.6 & 70.4 \\
\hline Emission BC & {$[\%]$} & 2.2 & -70.3 & -68.5 & -61.6 & -21.6 & -3.9 & -12.5 \\
\hline Burden BC & {$[\%]$} & 1.2 & -60.3 & -60.6 & -51.8 & -25.2 & -6.5 & -10.5 \\
\hline Emission POM & & -0.9 & -25.2 & -35.0 & -26.9 & -6.5 & -2.1 & -34.0 \\
\hline Burden POM & {$[\%]$} & -1.4 & -18.7 & -25.4 & -18.2 & -8.3 & -4.9 & -30.6 \\
\hline AOD & {$[\%]$} & 6.4 & -30.1 & -49.5 & -38.2 & -35.5 & -12.5 & 41.2 \\
\hline TOA forcing Total sky & {$\left[\mathrm{W} / \mathrm{m}^{2}\right]$} & -0.269 & 1.724 & 2.369 & 1.932 & 0.916 & 0.450 & -0.908 \\
\hline TOA forcing Clear sky & {$\left[\mathrm{W} / \mathrm{m}^{2}\right]$} & -0.153 & 0.922 & 2.011 & 1.287 & 0.636 & 0.401 & -1.461 \\
\hline \multicolumn{9}{|c|}{ Experiment MFR:2030:ASIA: MFR:2030:ASIA-2000 } \\
\hline Source $\mathrm{SO}_{2}$ & {$[\%]$} & 0.1 & -33.5 & -61.1 & -42.6 & -42.5 & -46.9 & -24.1 \\
\hline Burden $\mathrm{SO}_{4}$ & {$[\%]$} & -1.8 & -28.0 & -35.5 & -31.6 & -34.1 & -45.9 & -21.3 \\
\hline Emission $\mathrm{BC}$ & {$[\%]$} & 2.2 & -55.4 & -51.8 & -33.5 & 14.0 & -3.9 & -39.4 \\
\hline Burden BC & {$[\%]$} & 0.9 & -46.0 & -42.3 & -29.6 & -6.6 & -6.0 & -35.0 \\
\hline Emission POM & {$[\%]$} & -0.9 & -16.7 & -26.5 & -9.4 & 1.9 & -2.1 & -45.0 \\
\hline Burden POM & {$[\%]$} & -1.3 & -12.1 & -17.0 & -7.8 & -2.7 & -4.5 & -40.2 \\
\hline AOD & {$[\%]$} & -1.9 & -21.6 & -35.6 & -28.1 & -30.1 & -17.6 & -12.9 \\
\hline TOA forcing Total sky & {$\left[\mathrm{W} / \mathrm{m}^{2}\right]$} & 0.071 & 1.133 & 1.431 & 1.066 & 0.628 & 0.547 & 0.832 \\
\hline TOA forcing Clear sky & {$\left[\mathrm{W} / \mathrm{m}^{2}\right]$} & 0.034 & 0.657 & 1.308 & 0.866 & 0.516 & 0.569 & 0.366 \\
\hline
\end{tabular}


Table A1. Continued.

\begin{tabular}{|c|c|c|c|c|c|c|c|c|}
\hline & & $\begin{array}{l}\text { East } \\
\text { Asia }\end{array}$ & $\begin{array}{c}\text { South East } \\
\text { Asia }\end{array}$ & $\begin{array}{c}\text { Asia } \\
\text { Reg. Exp. }\end{array}$ & Japan & Greenland & Oceania & Global \\
\hline \multicolumn{9}{|c|}{ Experiment MFR:2030:EUROPE: MFR:2030:EUROPE-2000 } \\
\hline Source $\mathrm{SO}_{2}$ & {$[\%]$} & 2.9 & 98.4 & 37.4 & -15.6 & 12.2 & -27.1 & 0.2 \\
\hline Burden $\mathrm{SO}_{4}$ & {$[\%]$} & 3.7 & 39.0 & 34.2 & -0.6 & 11.6 & 1.6 & 6.8 \\
\hline Emission BC & {$[\%]$} & -17.6 & -4.1 & -13.9 & -57.3 & -10.0 & 1.7 & -13.1 \\
\hline Burden BC & {$[\%]$} & -15.8 & -8.8 & -12.9 & -23.0 & -15.3 & 1.2 & -9.0 \\
\hline Emission POM & & -35.8 & -10.9 & -26.6 & -16.8 & 0.2 & -0.1 & -8.7 \\
\hline Burden POM & {$[\%]$} & -28.9 & -14.3 & -25.3 & -23.9 & -9.0 & -0.4 & -6.8 \\
\hline AOD & {$[\%]$} & -0.4 & 24.2 & 16.5 & -4.0 & 5.6 & -1.7 & 1.3 \\
\hline TOA forcing Total sky & {$\left[\mathrm{W} / \mathrm{m}^{2}\right]$} & 0.130 & -0.491 & -0.311 & 0.789 & 0.004 & 0.007 & -0.001 \\
\hline TOA forcing Clear sky & {$\left[\mathrm{W} / \mathrm{m}^{2}\right]$} & -0.076 & -0.777 & -0.651 & 0.072 & 0.006 & 0.038 & -0.063 \\
\hline \multicolumn{9}{|c|}{ Experiment MFR:2030:ASIA: MFR:2030:ASIA-2000 } \\
\hline Source $\mathrm{SO}_{2}$ & {$[\%]$} & -68.1 & -45.5 & -59.5 & -15.6 & 12.2 & -27.1 & -19.8 \\
\hline Burden $\mathrm{SO}_{4}$ & {$[\%]$} & -52.8 & -30.9 & -36.1 & -38.3 & -23.8 & -8.1 & -16.2 \\
\hline Emission BC & {$[\%]$} & -35.8 & -16.8 & -34.2 & -57.3 & -10.0 & 1.7 & -19.2 \\
\hline Burden BC & {$[\%]$} & -31.9 & -19.7 & -31.0 & -34.2 & -18.9 & 1.2 & -13.2 \\
\hline Emission POM & {$[\%]$} & -49.9 & -16.1 & -37.2 & -16.8 & 0.2 & -0.1 & -10.5 \\
\hline Burden POM & {$[\%]$} & -39.4 & -19.0 & -33.9 & -32.0 & -10.1 & -0.3 & -7.8 \\
\hline AOD & {$[\%]$} & -46.1 & -24.2 & -30.5 & -29.2 & -17.9 & -2.8 & -6.5 \\
\hline TOA forcing Total sky & {$\left[\mathrm{W} / \mathrm{m}^{2}\right]$} & 1.204 & 1.365 & 1.204 & 1.845 & 0.046 & 0.036 & 0.322 \\
\hline TOA forcing Clear sky & {$\left[\mathrm{W} / \mathrm{m}^{2}\right]$} & 1.522 & 0.791 & 1.046 & 1.390 & 0.029 & 0.082 & 0.230 \\
\hline
\end{tabular}

Table A2. Changes in oxidant burdens up to $100 \mathrm{hPa}$ for the different air pollution scenarios as simulated in the offline chemistry model TM3 (Dentener et al., 2006b). Regions are defined as shown in Fig. A4.

\begin{tabular}{|c|c|c|c|c|c|c|c|c|}
\hline & & Canada & USA & $\begin{array}{l}\text { Central } \\
\text { America }\end{array}$ & $\begin{array}{c}\text { South } \\
\text { America }\end{array}$ & $\begin{array}{c}\text { Northern } \\
\text { Africa }\end{array}$ & $\begin{array}{c}\text { Western } \\
\text { Africa }\end{array}$ & $\begin{array}{l}\text { Eastern } \\
\text { Africa }\end{array}$ \\
\hline \multicolumn{9}{|l|}{2000} \\
\hline $\mathrm{O}_{3}$ & {$[\mathrm{Tg}]$} & 17.4 & 12.3 & 2.7 & 11.8 & 6.5 & 7.8 & 4.7 \\
\hline $\mathrm{OH}$ & {$[\mathrm{Mg}]$} & 1.4 & 2.5 & 1.7 & 7.8 & 2.2 & 5.7 & 3.4 \\
\hline $\mathrm{H}_{2} \mathrm{O}_{2}$ & {$[\mathrm{Gg}]$} & 40.8 & 53.0 & 31.9 & 245.1 & 48.2 & 168.9 & 78.7 \\
\hline $\mathrm{NO}_{2}$ & {$[\mathrm{Gg}]$} & 4.3 & 11.8 & 3.0 & 11.7 & 4.7 & 10.2 & 5.1 \\
\hline \multicolumn{9}{|c|}{ MFR:2030-2000 } \\
\hline $\mathrm{O}_{3}$ & {$[\%]$} & -4.3 & -6.5 & -9.6 & -6.6 & -6.5 & -6.1 & -6.9 \\
\hline $\mathrm{OH}$ & {$[\%]$} & 3.0 & -1.9 & -4.1 & -1.7 & 2.4 & 3.3 & 1.0 \\
\hline $\mathrm{H}_{2} \mathrm{O}_{2}$ & {$[\%]$} & -0.9 & 2.8 & -8.9 & -6.6 & -9.5 & -8.9 & -10.0 \\
\hline $\mathrm{NO}_{2}$ & {$[\%]$} & -18.8 & -35.8 & -27.3 & -14.8 & -12.0 & -3.8 & -5.7 \\
\hline \multicolumn{9}{|c|}{ CHEM:2030-2000 } \\
\hline $\mathrm{O}_{3}$ & {$[\%]$} & 5.0 & 6.3 & 7.5 & 3.9 & 7.8 & 7.6 & 8.8 \\
\hline $\mathrm{OH}$ & {$[\%]$} & 5.1 & 3.7 & -0.7 & -1.4 & -0.3 & -1.6 & -2.6 \\
\hline $\mathrm{H}_{2} \mathrm{O}_{2}$ & {$[\%]$} & 2.2 & 3.8 & 4.1 & 0.0 & 6.2 & 2.3 & 3.5 \\
\hline $\mathrm{NO}_{2}$ & {$[\%]$} & 18.6 & 13.0 & 1.7 & -2.1 & 14.3 & 3.6 & 4.7 \\
\hline \multicolumn{9}{|c|}{ MOZART-2000 } \\
\hline $\mathrm{O}_{3}$ & {$[\%]$} & 17.8 & 13.0 & -0.8 & 6.5 & -1.9 & 15.5 & 12.0 \\
\hline $\mathrm{OH}$ & {$[\%]$} & -84.4 & -54.1 & -27.2 & 50.9 & -32.4 & 18.6 & 26.8 \\
\hline $\mathrm{H}_{2} \mathrm{O}_{2}$ & {$[\%]$} & -63.9 & -42.3 & -32.3 & -20.3 & -19.5 & -33.6 & -12.8 \\
\hline $\mathrm{NO}_{2}$ & {$[\%]$} & 225.3 & 239.8 & 25.2 & 47.0 & 10.9 & 61.9 & 103.0 \\
\hline
\end{tabular}


Table A2. Continued.

\begin{tabular}{|c|c|c|c|c|c|c|c|c|}
\hline & & $\begin{array}{l}\text { Southern } \\
\text { Africa }\end{array}$ & $\begin{array}{l}\text { Europe } \\
\text { OECD }\end{array}$ & $\begin{array}{l}\text { Europe } \\
\text { Eastern }\end{array}$ & $\begin{array}{l}\text { USSR } \\
\text { former }\end{array}$ & Middle East & $\begin{array}{c}\text { South } \\
\text { Asia }\end{array}$ & $\begin{array}{l}\text { East } \\
\text { Asia }\end{array}$ \\
\hline \multicolumn{9}{|l|}{2000} \\
\hline $\mathrm{O}_{3}$ & {$[\mathrm{Tg}]$} & 5.1 & 6.6 & 1.7 & 34.3 & 7.0 & 5.1 & 13.8 \\
\hline $\mathrm{OH}$ & {$[\mathrm{Mg}]$} & 3.3 & 0.9 & 0.2 & 3.4 & 2.4 & 2.7 & 3.6 \\
\hline $\mathrm{H}_{2} \mathrm{O}_{2}$ & {$[\mathrm{Gg}]$} & 73.2 & 17.5 & 3.8 & 75.5 & 49.5 & 52.2 & 61.3 \\
\hline $\mathrm{NO}_{2}$ & {$[\mathrm{Gg}]$} & 6.2 & 8.3 & 3.0 & 15.8 & 6.0 & 5.0 & 9.6 \\
\hline \multicolumn{9}{|c|}{ MFR:2030-2000 } \\
\hline $\mathrm{O}_{3}$ & {$[\%]$} & -5.1 & -4.9 & -5.2 & -4.8 & -7.9 & -8.1 & -6.9 \\
\hline $\mathrm{OH}$ & {$[\%]$} & 1.9 & 7.6 & 6.4 & 0.8 & -3.8 & -2.1 & -6.3 \\
\hline $\mathrm{H}_{2} \mathrm{O}_{2}$ & {$[\%]$} & -4.6 & -0.3 & 10.3 & 4.7 & -6.7 & -8.8 & 6.4 \\
\hline $\mathrm{NO}_{2}$ & {$[\%]$} & -7.7 & -28.0 & -44.8 & -35.8 & -26.4 & -15.8 & -30.7 \\
\hline \multicolumn{9}{|c|}{ CHEM:2030-2000 } \\
\hline $\mathrm{O}_{3}$ & {$[\%]$} & 5.7 & 5.8 & 5.7 & 5.0 & 7.8 & 11.9 & 7.3 \\
\hline $\mathrm{OH}$ & {$[\%]$} & 0.0 & 2.7 & 1.0 & 0.2 & -4.6 & 2.0 & -0.8 \\
\hline $\mathrm{H}_{2} \mathrm{O}_{2}$ & {$[\%]$} & 2.8 & 9.5 & 17.2 & 9.4 & 7.9 & -4.0 & 0.9 \\
\hline $\mathrm{NO}_{2}$ & {$[\%]$} & 7.6 & -13.1 & -22.4 & -2.4 & 1.1 & 29.9 & 16.4 \\
\hline \multicolumn{9}{|c|}{ MOZART-2000 } \\
\hline $\mathrm{O}_{3}$ & [\%] & -19.3 & 6.9 & 9.4 & 18.6 & 6.5 & 6.3 & 23.2 \\
\hline $\mathrm{OH}$ & {$[\%]$} & 49.8 & -63.8 & -61.4 & -83.2 & -23.1 & -32.7 & -53.4 \\
\hline $\mathrm{H}_{2} \mathrm{O}_{2}$ & {$[\%]$} & -23.1 & -19.3 & 5.2 & -40.3 & -7.8 & -7.3 & -17.5 \\
\hline \multirow[t]{2}{*}{$\mathrm{NO}_{2}$} & {$[\%]$} & -16.4 & 129.5 & 62.2 & 11.2 & 35.3 & 42.9 & 100.5 \\
\hline & & $\begin{array}{c}\text { South East } \\
\text { Asia }\end{array}$ & $\begin{array}{c}\text { Asia } \\
\text { Reg. Exp. }\end{array}$ & Japan & Greenland & Oceania & Global & \\
\hline \multicolumn{9}{|l|}{2000} \\
\hline $\mathrm{O}_{3}$ & {$[\mathrm{Tg}]$} & 3.3 & 21.4 & 0.7 & 3.5 & 6.9 & 468.11 & \\
\hline $\mathrm{OH}$ & {$[\mathrm{Mg}]$} & 3.4 & 12.0 & 0.2 & 0.2 & 3.3 & 173.6 & \\
\hline $\mathrm{H}_{2} \mathrm{O}_{2}$ & {$[\mathrm{Gg}]$} & 78.5 & 241.1 & 3.1 & 5.7 & 64.9 & 3491.8 & \\
\hline $\mathrm{NO}_{2}$ & {$[\mathrm{Gg}]$} & 4.1 & 19.9 & 0.6 & 0.4 & 4.4 & 243.9 & \\
\hline \multicolumn{9}{|c|}{ MFR:2030-2000 } \\
\hline $\mathrm{O}_{3}$ & {$[\%]$} & -10.1 & -7.9 & -7.2 & -3.7 & -4.4 & -5.1 & \\
\hline $\mathrm{OH}$ & {$[\%]$} & -3.9 & -3.6 & -2.6 & 4.8 & 0.3 & 1.0 & \\
\hline $\mathrm{H}_{2} \mathrm{O}_{2}$ & {$[\%]$} & -10.3 & -6.1 & 4.1 & -2.0 & -5.4 & -7.9 & \\
\hline $\mathrm{NO}_{2}$ & {$[\%]$} & -18.4 & -22.8 & -32.5 & -4.9 & -10.6 & -14.6 & \\
\hline \multicolumn{9}{|c|}{ CHEM:2030-2000 } \\
\hline $\mathrm{O}_{3}$ & {$[\%]$} & 11.8 & 9.5 & 7.0 & 4.6 & 4.7 & 5.7 & \\
\hline $\mathrm{OH}$ & {$[\%]$} & -1.2 & -0.5 & 0.1 & 4.3 & -2.9 & -1.2 & \\
\hline $\mathrm{H}_{2} \mathrm{O}_{2}$ & {$[\%]$} & 2.6 & 1.0 & 2.7 & 2.5 & 5.2 & 3.2 & \\
\hline $\mathrm{NO}_{2}$ & {$[\%]$} & 12.2 & 18.0 & 8.7 & 21.4 & 0.1 & 6.5 & \\
\hline \multicolumn{9}{|c|}{ MOZART-2000 } \\
\hline $\mathrm{O}_{3}$ & {$[\%]$} & -0.4 & 12.1 & 31.6 & 1.7 & -20.4 & 0.1 & \\
\hline $\mathrm{OH}$ & {$[\%]$} & 1.2 & -22.1 & -68.3 & -98.7 & 74.8 & 5.3 & \\
\hline $\mathrm{H}_{2} \mathrm{O}_{2}$ & {$[\%]$} & -24.6 & -21.6 & -45.6 & -60.9 & 7.2 & -9.7 & \\
\hline $\mathrm{NO}_{2}$ & {$[\%]$} & 34.9 & 55.2 & 206.0 & 254.9 & 36.2 & 57.8 & \\
\hline
\end{tabular}


Table A3. Regional Budgets for Chemistry Sensitivity experiments. Regions are defined as shown in Fig. A4.

\begin{tabular}{|c|c|c|c|c|c|c|c|c|}
\hline & & CAN & USA & $\begin{array}{l}\text { Central } \\
\text { America }\end{array}$ & $\begin{array}{c}\text { South } \\
\text { America }\end{array}$ & $\begin{array}{c}\text { Northern } \\
\text { Africa }\end{array}$ & $\begin{array}{l}\text { Western } \\
\text { Africa }\end{array}$ & $\begin{array}{r}\text { Eastern } \\
\text { Africa }\end{array}$ \\
\hline \multicolumn{9}{|l|}{ Experiment 2000} \\
\hline Emission $\mathrm{SO}_{2}$ & {$[\mathrm{Gg}(\mathrm{S}) / \mathrm{yr}]$} & 920.7 & 8464.0 & 2033.9 & 4479.2 & 810.1 & 781.6 & 438.5 \\
\hline Burden $\mathrm{SO}_{4}$ & {$[\mathrm{Gg}(\mathrm{S})]$} & 8.1 & 24.0 & 10.4 & 27.7 & 28.4 & 35.7 & 24.7 \\
\hline $\mathrm{SO}_{4}$ gas-phase prod. & {$[\mathrm{Gg}(\mathrm{S}) / \mathrm{yr}]$} & 199.0 & 1359.4 & 524.4 & 960.8 & 879.9 & 683.7 & 503.4 \\
\hline $\mathrm{SO}_{4}$ aqueous-phase prod. & {$[\mathrm{Gg}(\mathrm{S}) / \mathrm{yr}]$} & 868.7 & 2069.6 & 573.9 & 1362.8 & 120.3 & 351.2 & 211.6 \\
\hline AOD & {$[* 100]$} & 3.0 & 11.2 & 16.7 & 13.1 & 19.3 & 31.8 & 21.1 \\
\hline TOA forcing Total sky & {$\left[\mathrm{W} / \mathrm{m}^{2}\right]$} & 1.387 & 2.732 & 3.207 & 1.814 & 0.615 & 0.677 & 2.289 \\
\hline TOA forcing Clear sky & {$\left[\mathrm{W} / \mathrm{m}^{2}\right]$} & 0.646 & 1.883 & 1.608 & 0.569 & 0.206 & 0.819 & 1.021 \\
\hline \multicolumn{9}{|l|}{ Experiment MFR:2030 } \\
\hline Emission $\mathrm{SO}_{2}$ & {$[\mathrm{Gg}(\mathrm{S}) / \mathrm{yr}]$} & 255.0 & 1481.9 & 822.2 & 3670.9 & 163.7 & 634.6 & 356.5 \\
\hline Burden $\mathrm{SO}_{4}$ & {$[\mathrm{Gg}(\mathrm{S})]$} & 3.9 & 7.9 & 4.9 & 22.6 & 15.4 & 21.7 & 11.8 \\
\hline $\mathrm{SO}_{4}$ gas-phase prod. & {$[\mathrm{Gg}(\mathrm{S}) / \mathrm{yr}]$} & 69.1 & 283.3 & 232.3 & 813.1 & 498.2 & 492.7 & 277.5 \\
\hline $\mathrm{SO}_{4}$ aqueous-phase prod & {$[\mathrm{Gg}(\mathrm{S}) / \mathrm{yr}]$} & 288.3 & 522.7 & 246.3 & 1061.1 & 60.4 & 264.8 & 138.0 \\
\hline AOD & {$[* 100]$} & 1.3 & 4.2 & 10.5 & 11.6 & 15.6 & 27.4 & 14.9 \\
\hline TOA forcing Total sky & {$\left[\mathrm{W} / \mathrm{m}^{2}\right]$} & 1.109 & 1.640 & 1.726 & 0.798 & 0.525 & 0.421 & 1.037 \\
\hline TOA forcing Clear sky & {$\left[\mathrm{W} / \mathrm{m}^{2}\right]$} & 0.517 & 1.477 & 1.229 & 0.260 & 0.320 & 0.588 & 0.878 \\
\hline \multicolumn{9}{|l|}{ Experiment CLE:2030 } \\
\hline Emission $\mathrm{SO}_{2}$ & {$[\mathrm{Gg}(\mathrm{S}) / \mathrm{yr}]$} & 925.0 & 7974.9 & 1277.9 & 4863.9 & 943.5 & 867.4 & 489.8 \\
\hline Burden $\mathrm{SO}_{4}$ & {$[\mathrm{Gg}(\mathrm{S})]$} & 8.6 & 23.7 & 9.5 & 29.9 & 25.1 & 35.7 & 26.3 \\
\hline $\mathrm{SO}_{4}$ gas-phase prod. & {$[\mathrm{Gg}(\mathrm{S}) / \mathrm{yr}]$} & 193.5 & 1311.3 & 423.0 & 1019.6 & 816.1 & 718.2 & 533.4 \\
\hline $\mathrm{SO}_{4}$ aqueous-phase prod. & {$[\mathrm{Gg}(\mathrm{S}) / \mathrm{yr}]$} & 841.1 & 1985.5 & 410.4 & 1511.6 & 116.7 & 373.1 & 234.6 \\
\hline $\mathrm{AOD}$ & {$[* 100]$} & 2.9 & 10.7 & 15.4 & 13.5 & 18.2 & 31.9 & 21.6 \\
\hline TOA forcing Total sky & {$\left[\mathrm{W} / \mathrm{m}^{2}\right]$} & 0.085 & 0.070 & 0.652 & 0.382 & 0.099 & -0.206 & -0.208 \\
\hline \multirow[t]{2}{*}{ TOA forcing Clear sky } & {$\left[\mathrm{W} / \mathrm{m}^{2}\right]$} & 0.014 & 0.039 & 0.199 & -0.109 & 0.059 & -0.089 & -0.214 \\
\hline & & $\begin{array}{c}\text { Southern } \\
\text { Africa }\end{array}$ & $\begin{array}{l}\text { Europe } \\
\text { OECD }\end{array}$ & $\begin{array}{l}\text { Europe } \\
\text { Eastern }\end{array}$ & $\begin{array}{l}\text { USSR } \\
\text { former }\end{array}$ & Middle East & $\begin{array}{l}\text { South } \\
\text { Asia }\end{array}$ & $\begin{array}{l}\text { East } \\
\text { Asia }\end{array}$ \\
\hline \multicolumn{9}{|l|}{ Experiment 2000} \\
\hline Emission $\mathrm{SO}_{2}$ & {$[\mathrm{Gg}(\mathrm{S}) / \mathrm{yr}]$} & 1730.2 & 5702.2 & 3020.2 & 5590.4 & 3050.8 & 3694.2 & 15161.6 \\
\hline Burden $\mathrm{SO}_{4}$ & {$[\mathrm{Gg}(\mathrm{S})]$} & 13.0 & 9.9 & 4.2 & 32.2 & 31.0 & 23.8 & 36.3 \\
\hline $\mathrm{SO}_{4}$ gas-phase prod. & {$[\mathrm{Gg}(\mathrm{S}) / \mathrm{yr}]$} & 431.8 & 469.4 & 253.8 & 1039.8 & 1046.0 & 1205.1 & 2147.6 \\
\hline $\mathrm{SO}_{4}$ aqueous-phase prod. & {$[\mathrm{Gg}(\mathrm{S}) / \mathrm{yr}]$} & 529.7 & 1226.6 & 471.1 & 2046.6 & 399.1 & 507.0 & 4773.7 \\
\hline AOD & {$[* 100]$} & 12.7 & 14.0 & 20.1 & 7.5 & 16.1 & 20.6 & 19.2 \\
\hline TOA forcing Total sky & {$\left[\mathrm{W} / \mathrm{m}^{2}\right]$} & 2.371 & 5.620 & 5.695 & 2.555 & 1.381 & 2.461 & 4.187 \\
\hline TOA forcing Clear sky & {$\left[\mathrm{W} / \mathrm{m}^{2}\right]$} & 0.863 & 1.770 & 3.076 & 1.223 & 1.089 & 1.182 & 2.342 \\
\hline \multicolumn{9}{|l|}{ Experiment MFR:2030 } \\
\hline Emission $\mathrm{SO}_{2}$ & {$[\mathrm{Gg}(\mathrm{S}) / \mathrm{yr}]$} & 636.0 & 2953.2 & 303.6 & 963.5 & 258.8 & 1623.2 & 4101.2 \\
\hline Burden $\mathrm{SO}_{4}$ & {$[\mathrm{Gg}(\mathrm{S})]$} & 8.6 & 4.4 & 1.5 & 11.9 & 10.2 & 9.6 & 12.0 \\
\hline $\mathrm{SO}_{4}$ gas-phase prod. & {$[\mathrm{Gg}(\mathrm{S}) / \mathrm{yr}]$} & 249.6 & 190.5 & 51.8 & 254.9 & 220.4 & 472.7 & 493.1 \\
\hline $\mathrm{SO}_{4}$ aqueous-phase prod & {$[\mathrm{Gg}(\mathrm{S}) / \mathrm{yr}]$} & 230.3 & 426.7 & 110.4 & 581.9 & 93.5 & 258.1 & 1572.5 \\
\hline AOD & {$[* 100]$} & 10.1 & 8.2 & 8.3 & 3.6 & 9.6 & 13.2 & 7.6 \\
\hline TOA forcing Total sky & {$\left[\mathrm{W} / \mathrm{m}^{2}\right]$} & 1.126 & 2.850 & 3.269 & 1.717 & 1.080 & 1.267 & 1.702 \\
\hline TOA forcing Clear sky & {$\left[\mathrm{W} / \mathrm{m}^{2}\right]$} & 0.519 & 1.366 & 2.475 & 1.007 & 1.030 & 0.991 & 1.844 \\
\hline \multicolumn{9}{|l|}{ Experiment CLE:2030 } \\
\hline Emission $\mathrm{SO}_{2}$ & {$[\mathrm{Gg}(\mathrm{S}) / \mathrm{yr}]$} & 1731.3 & 3794.8 & 1173.5 & 3217.0 & 1316.4 & 10794.1 & 15602.6 \\
\hline Burden $\mathrm{SO}_{4}$ & {$[\mathrm{Gg}(\mathrm{S})]$} & 14.5 & 8.1 & 3.0 & 25.8 & 25.8 & 44.7 & 39.1 \\
\hline $\mathrm{SO}_{4}$ gas-phase prod. & {$[\mathrm{Gg}(\mathrm{S}) / \mathrm{yr}]$} & 451.0 & 306.3 & 119.0 & 672.9 & 652.5 & 3189.9 & 2266.0 \\
\hline $\mathrm{SO}_{4}$ aqueous-phase prod. & {$[\mathrm{Gg}(\mathrm{S}) / \mathrm{yr}]$} & 543.9 & 795.9 & 272.5 & 1380.5 & 245.9 & 1175.6 & 5062.5 \\
\hline AOD & {$[* 100]$} & 13.5 & 11.4 & 13.8 & 5.8 & 14.2 & 30.6 & 19.6 \\
\hline TOA forcing Total sky & {$\left[\mathrm{W} / \mathrm{m}^{2}\right]$} & -0.277 & 1.009 & 1.504 & 0.486 & 0.328 & -1.094 & 0.053 \\
\hline TOA forcing Clear sky & {$\left[\mathrm{W} / \mathrm{m}^{2}\right]$} & -0.151 & 0.547 & 1.237 & 0.395 & 0.308 & -1.734 & -0.170 \\
\hline
\end{tabular}


Table A3. Continued.

\begin{tabular}{|c|c|c|c|c|c|c|c|c|}
\hline & & $\begin{array}{c}\text { South East } \\
\text { Asia }\end{array}$ & $\begin{array}{c}\text { Asia } \\
\text { Reg. Exp. }\end{array}$ & Japan & Greenland & Oceania & Global & \\
\hline \multicolumn{9}{|l|}{ Experiment 2000} \\
\hline Emission $\mathrm{SO}_{2}$ & {$[\mathrm{Gg}(\mathrm{S}) / \mathrm{yr}]$} & 1931.0 & 23256.9 & 972.9 & 3.2 & 1253.0 & 95994.8 & \\
\hline Burden $\mathrm{SO}_{4}$ & {$[\mathrm{Gg}(\mathrm{S})]$} & 13.0 & 78.8 & 1.8 & 1.0 & 10.0 & 857.8 & \\
\hline $\mathrm{SO}_{4}$ gas-phase prod. & {$[\mathrm{Gg}(\mathrm{S}) / \mathrm{yr}]$} & 561.6 & 4614.9 & 121.4 & 15.7 & 283.7 & 28954.9 & \\
\hline $\mathrm{SO}_{4}$ aqueous-phase prod. & {$[\mathrm{Gg}(\mathrm{S}) / \mathrm{yr}]$} & 641.1 & 6256.0 & 275.4 & 13.7 & 359.5 & 37535.3 & \\
\hline AOD & {$[* 100]$} & 15.5 & 19.1 & 22.3 & 0.5 & 11.1 & 16.2 & \\
\hline TOA forcing Total sky & {$\left[\mathrm{W} / \mathrm{m}^{2}\right]$} & 3.910 & 3.633 & 5.954 & 0.153 & 0.951 & 2.047 & \\
\hline TOA forcing Clear sky & {$\left[\mathrm{W} / \mathrm{m}^{2}\right]$} & 1.481 & 1.837 & 2.698 & 0.081 & 0.272 & 0.824 & \\
\hline \multicolumn{9}{|l|}{ Experiment MFR:2030 } \\
\hline Emission $\mathrm{SO}_{2}$ & {$[\mathrm{Gg}(\mathrm{S}) / \mathrm{yr}]$} & 1053.1 & 9416.5 & 705.6 & 3.1 & 538.8 & 53294.1 & \\
\hline Burden $\mathrm{SO}_{4}$ & {$[\mathrm{Gg}(\mathrm{S})]$} & 7.5 & 35.8 & 0.8 & 0.6 & 7.6 & 525.8 & \\
\hline $\mathrm{SO}_{4}$ gas-phase prod. & {$[\mathrm{Gg}(\mathrm{S}) / \mathrm{yr}]$} & 339.0 & 2009.2 & 58.8 & 7.1 & 183.5 & 16868.1 & \\
\hline $\mathrm{SO}_{4}$ aqueous-phase prod & {$[\mathrm{Gg}(\mathrm{S}) / \mathrm{yr}]$} & 383.6 & 2538.0 & 194.6 & 7.8 & 219.6 & 21919.4 & \\
\hline AOD & {$[* 100]$} & 9.9 & 10.5 & 12.0 & 0.3 & 10.0 & 13.6 & \\
\hline TOA forcing Total sky & {$\left[\mathrm{W} / \mathrm{m}^{2}\right]$} & 1.524 & 1.479 & 3.431 & 0.106 & 0.293 & 1.132 & \\
\hline TOA forcing Clear sky & {$\left[\mathrm{W} / \mathrm{m}^{2}\right]$} & 1.033 & 1.396 & 2.029 & 0.068 & 0.220 & 0.580 & \\
\hline \multicolumn{9}{|l|}{ Experiment CLE:2030 } \\
\hline Emission $\mathrm{SO}_{2}$ & {$[\mathrm{Gg}(\mathrm{S}) / \mathrm{yr}]$} & 3830.5 & 31960.1 & 821.3 & 3.6 & 913.2 & 99573.2 & \\
\hline Burden $\mathrm{SO}_{4}$ & {$[\mathrm{Gg}(\mathrm{S})]$} & 18.5 & 111.4 & 1.9 & 1.1 & 10.1 & 936.3 & \\
\hline $\mathrm{SO}_{4}$ gas-phase prod. & {$[\mathrm{Gg}(\mathrm{S}) / \mathrm{yr}]$} & 915.4 & 7244.7 & 113.4 & 14.2 & 254.3 & 32387.8 & \\
\hline $\mathrm{SO}_{4}$ aqueous-phase prod. & {$[\mathrm{Gg}(\mathrm{S}) / \mathrm{yr}]$} & 996.0 & 7577.5 & 260.9 & 12.8 & 309.3 & 38427.2 & \\
\hline AOD & {$[* 100]$} & 19.6 & 22.8 & 21.7 & 0.6 & 10.8 & 16.6 & \\
\hline TOA forcing Total sky & {$\left[\mathrm{W} / \mathrm{m}^{2}\right]$} & -0.266 & -0.292 & 0.454 & -0.002 & 0.054 & 0.016 & \\
\hline \multirow[t]{2}{*}{ TOA forcing Clear sky } & {$\left[\mathrm{W} / \mathrm{m}^{2}\right]$} & -0.844 & -0.770 & -0.002 & -0.005 & 0.050 & -0.096 & \\
\hline & & CAN & USA & $\begin{array}{l}\text { Central } \\
\text { America }\end{array}$ & $\begin{array}{c}\text { South } \\
\text { America }\end{array}$ & $\begin{array}{c}\text { Northern } \\
\text { Africa }\end{array}$ & $\begin{array}{l}\text { Western } \\
\text { Africa }\end{array}$ & $\begin{array}{c}\text { Eastern } \\
\text { Africa }\end{array}$ \\
\hline \multicolumn{9}{|c|}{ Experiment diff 2000:CHEM:2030:MFR-2000 } \\
\hline Burden $\mathrm{SO}_{4}$ & [\%] & 0.8 & -2.2 & -2.3 & 0.3 & 0.9 & 1.3 & -0.0 \\
\hline $\mathrm{SO}_{4}$ gas-phase prod. & {$[\%]$} & -1.1 & -8.8 & -8.2 & -2.0 & 0.4 & 3.5 & 1.7 \\
\hline $\mathrm{SO}_{4}$ aqueous-phase prod. & {$[\%]$} & 3.4 & 7.9 & 1.5 & -0.4 & 2.7 & -2.9 & 0.7 \\
\hline AOD & {$[\%]$} & 0.1 & -1.9 & -1.7 & -0.1 & -0.5 & -0.4 & -0.2 \\
\hline TOA forcing Total sky & {$\left[\mathrm{W} / \mathrm{m}^{2}\right]$} & -0.02 & 0.01 & -0.09 & 0.13 & 0.07 & -0.11 & -0.14 \\
\hline TOA forcing Clear sky & {$\left[\mathrm{W} / \mathrm{m}^{2}\right]$} & 0.01 & 0.05 & 0.06 & 0 & -0.01 & $7-0.02$ & 0.01 \\
\hline \multicolumn{9}{|c|}{ Experiment diff MFR:2030:CHEM:2000-2030:MFR } \\
\hline Burden $\mathrm{SO}_{4}$ & {$[\%]$} & -1.0 & 0.7 & 1.3 & -0.2 & -0.8 & -1.0 & -0.4 \\
\hline $\mathrm{SO}_{4}$ gas-phase prod. & [\%] & -0.8 & 6.6 & 4.6 & 1.7 & -0.3 & -3.7 & -1.8 \\
\hline $\mathrm{SO}_{4}$ aqueous-phase prod. & {$[\%]$} & -1.5 & -4.3 & -0.5 & 0.3 & -1.2 & 3.1 & 1.6 \\
\hline AOD & {$[\%]$} & -0.3 & 0.6 & 1.4 & 0.5 & 1.0 & 1.1 & 0.4 \\
\hline TOA forcing Total sky & {$\left[\mathrm{W} / \mathrm{m}^{2}\right]$} & 0.01 & 0.08 & 0.23 & 0.08 & 0 & 0.13 & -0.08 \\
\hline TOA forcing Clear sky & {$\left[\mathrm{W} / \mathrm{m}^{2}\right]$} & -0.01 & 0 & -0.03 & -0.01 & 0 & -0.02 & 0 \\
\hline \multicolumn{9}{|c|}{ Experiment diff CLE:2030:CHEM:2000-CLE:2030 } \\
\hline Burden $\mathrm{SO}_{4}$ & [\%] & -0.2 & -0.5 & 0.2 & -0.1 & 0.5 & 0.6 & 1.3 \\
\hline $\mathrm{SO}_{4}$ gas-phase prod. & [\%] & -2.7 & -1.5 & 1.8 & 0.5 & 0.5 & 0.2 & 1.7 \\
\hline $\mathrm{SO}_{4}$ aqueous-phase prod. & [\%] & -0.5 & -0.6 & -0.2 & 0.7 & -3.6 & -1.2 & -2.1 \\
\hline AOD & {$[\%]$} & -0.6 & -0.6 & -0.2 & 0.2 & -0.9 & -0.6 & 0.8 \\
\hline TOA forcing Total sky & {$\left[\mathrm{W} / \mathrm{m}^{2}\right]$} & 0.04 & 0.06 & -0.03 & -0.04 & 0.03 & 0.1 & -0.11 \\
\hline TOA forcing Clear sky & {$\left[\mathrm{W} / \mathrm{m}^{2}\right]$} & -0.01 & 0 & 0.01 & 0 & 0.01 & 0.01 & -0.03 \\
\hline
\end{tabular}


Table A3. Continued.

\begin{tabular}{|c|c|c|c|c|c|c|c|c|}
\hline & & $\begin{array}{c}\text { Southern } \\
\text { Africa }\end{array}$ & $\begin{array}{l}\text { Europe } \\
\text { OECD }\end{array}$ & $\begin{array}{l}\text { Europe } \\
\text { Eastern }\end{array}$ & $\begin{array}{l}\text { USSR } \\
\text { former }\end{array}$ & Middle East & $\begin{array}{l}\text { South } \\
\text { Asia }\end{array}$ & $\begin{array}{l}\text { East } \\
\text { Asia }\end{array}$ \\
\hline \multicolumn{9}{|c|}{ Experiment diff 2000:CHEM:2030:MFR-2000 } \\
\hline Burden $\mathrm{SO}_{4}$ & {$[\%]$} & 0.2 & 1.7 & 3.7 & 1.1 & -2.8 & -2.8 & -2.6 \\
\hline $\mathrm{SO}_{4}$ gas-phase prod. & {$[\%]$} & -1.8 & -0.1 & -2.4 & -5.3 & -6.9 & -4.4 & -17.0 \\
\hline $\mathrm{SO}_{4}$ aqueous - phase prod. & {$[\%]$} & 0.4 & 3.0 & 13.7 & 9.3 & 6.9 & 1.9 & 10.4 \\
\hline AOD & {$[\%]$} & -0.4 & 1.4 & 3.7 & 1.2 & -1.1 & -1.3 & -1.6 \\
\hline TOA forcing Total sky & {$\left[\mathrm{W} / \mathrm{m}^{2}\right]$} & 0.02 & -0.13 & -0.03 & 0.01 & 0.03 & 0.14 & 0.08 \\
\hline TOA forcing Clear sky & {$\left[\mathrm{W} / \mathrm{m}^{2}\right]$} & 0 & -0.03 & -0.13 & -0.02 & 0.04 & 0.05 & 0.06 \\
\hline \multicolumn{9}{|c|}{ Experiment diff MFR:2030:CHEM:2000-2030:MFR } \\
\hline Burden $\mathrm{SO}_{4}$ & {$[\%]$} & -1.1 & -1.3 & -2.4 & -1.4 & 0.5 & 2.2 & 1.9 \\
\hline $\mathrm{SO}_{4}$ gas-phase prod. & {$[\%]$} & -1.6 & -1.2 & -1.4 & 2.3 & 2.7 & 4,70 & 16.3 \\
\hline $\mathrm{SO}_{4}$ aqueous-phase prod. & {$[\%]$} & 1.6 & -0.3 & -6.5 & -4.9 & -2.3 & -1.3 & -6.4 \\
\hline AOD & {$[\%]$} & -0.1 & -0.8 & -2.2 & -0.6 & 0.6 & 0.6 & 1.1 \\
\hline TOA forcing Total sky & {$\left[\mathrm{W} / \mathrm{m}^{2}\right]$} & 0.11 & 0.11 & 0.01 & 0.04 & 0 & 0.03 & -0.01 \\
\hline TOA forcing Clear sky & {$\left[\mathrm{W} / \mathrm{m}^{2}\right]$} & 0.01 & 0.02 & 0.02 & 0 & -0.01 & -0.02 & -0.02 \\
\hline
\end{tabular}

Experiment diff CLE:2030:CHEM:2000-CLE:2030

\begin{tabular}{|c|c|c|c|c|c|c|c|c|}
\hline Burden $\mathrm{SO}_{4}$ & {$[\%]$} & -0.1 & -0.0 & -1.0 & 0.4 & 1.2 & -4.5 & 0.8 \\
\hline $\mathrm{SO}_{4}$ gas-phase prod. & {$[\%]$} & -0.8 & 3.5 & 4.3 & 4.1 & 1.4 & -7.2 & 1.8 \\
\hline $\mathrm{SO}_{4}$ aqueous-phase prod. & {$[\%]$} & 0.2 & -2.4 & -6.7 & -4.2 & -1.3 & 3.7 & 1.1 \\
\hline AOD & {$[\%]$} & -0.1 & -0.7 & -1.7 & -0.3 & 0.4 & -2.3 & 0.6 \\
\hline TOA forcing Total sky & {$\left[\mathrm{W} / \mathrm{m}^{2}\right]$} & 0.02 & -0.05 & -0.06 & -0.03 & -0.03 & 0.02 & -0.06 \\
\hline \multirow[t]{2}{*}{ TOA forcing Clear sky } & {$\left[\mathrm{W} / \mathrm{m}^{2}\right]$} & 0 & 0.02 & 0.03 & -0.01 & -0.02 & 0.13 & -0.02 \\
\hline & & $\begin{array}{c}\text { South East } \\
\text { Asia }\end{array}$ & $\begin{array}{c}\text { Asia } \\
\text { Reg. Exp. }\end{array}$ & Japan & Greenland & Oceania & Global & \\
\hline \multicolumn{9}{|c|}{ Experiment diff 2000:CHEM:2030:MFR-2000 } \\
\hline Burden $\mathrm{SO}_{4}$ & {$[\%]$} & -2.0 & -2.4 & -2.2 & 1.3 & 0.2 & 0.1 & \\
\hline $\mathrm{SO}_{4}$ gas-phase prod. & {$[\%]$} & -5.8 & -9.8 & -8.2 & 1.2 & -4.5 & -2.4 & \\
\hline $\mathrm{SO}_{4}$ aqueous-phase prod. & {$[\%]$} & 1.1 & 7.9 & 6.0 & 0.8 & 0.0 & 2.6 & \\
\hline AOD & {$[\%]$} & -1.6 & -1.5 & -1.9 & 1.3 & 0.1 & -0.1 & \\
\hline TOA forcing Total sky & {$\left[\mathrm{W} / \mathrm{m}^{2}\right]$} & -0.05 & 0.02 & 0.31 & -0.01 & -0.01 & -0.05 & \\
\hline TOA forcing Clear sky & {$\left[\mathrm{W} / \mathrm{m}^{2}\right]$} & 0.05 & 0.06 & 0.07 & -0.01 & 0 & 0 & \\
\hline \multicolumn{9}{|c|}{ Experiment diff MFR:2030:CHEM:2000-2030:MFR } \\
\hline Burden $\mathrm{SO}_{4}$ & {$[\%]$} & 1.5 & 1.8 & 1.4 & -0.9 & -0.5 & -0.5 & \\
\hline $\mathrm{SO}_{4}$ gas-phase prod. & {$[\%]$} & 4.5 & 5.7 & 9.1 & -1.3 & 1.8 & 0.3 & \\
\hline $\mathrm{SO}_{4}$ aqueous-phase prod. & {$[\%]$} & -0.3 & -2.8 & -4.1 & 0.8 & 1.1 & -0.2 & \\
\hline AOD & {$[\%]$} & 1.4 & 1.1 & 0.6 & -0.1 & 0.2 & 0.1 & \\
\hline TOA forcing Total sky & {$\left[\mathrm{W} / \mathrm{m}^{2}\right]$} & 0.25 & 0.07 & -0.25 & 0.01 & 0.17 & 0.06 & \\
\hline TOA forcing Clear sky & {$\left[\mathrm{W} / \mathrm{m}^{2}\right]$} & -0.03 & -0.02 & -0.04 & 0.01 & 0 & 0 & \\
\hline \multicolumn{9}{|c|}{ Experiment diff CLE:2030:CHEM:2000-CLE:2030 } \\
\hline Burden $\mathrm{SO}_{4}$ & {$[\%]$} & -0.0 & -1.5 & 1.6 & 0.5 & 0.5 & -0.0 & \\
\hline $\mathrm{SO}_{4}$ gas-phase prod. & {$[\%]$} & 0.3 & -2.3 & 3.4 & 1.7 & 3.3 & 0.4 & \\
\hline $\mathrm{SO}_{4}$ aqueous-phase prod. & {$[\%]$} & 0.4 & 1.3 & -0.3 & 0.8 & -1.5 & -0.5 & \\
\hline AOD & {$[\%]$} & 0.3 & -0.3 & 1.4 & 0.3 & 0.8 & 0.0 & \\
\hline TOA forcing Total sky & {$\left[\mathrm{W} / \mathrm{m}^{2}\right]$} & -0.03 & -0.1 & -0.27 & 0 & -0.13 & -0.06 & \\
\hline TOA forcing Clear sky & {$\left[\mathrm{W} / \mathrm{m}^{2}\right]$} & -0.02 & 0.01 & -0.03 & 0 & -0.02 & -0.01 & \\
\hline
\end{tabular}


(a)

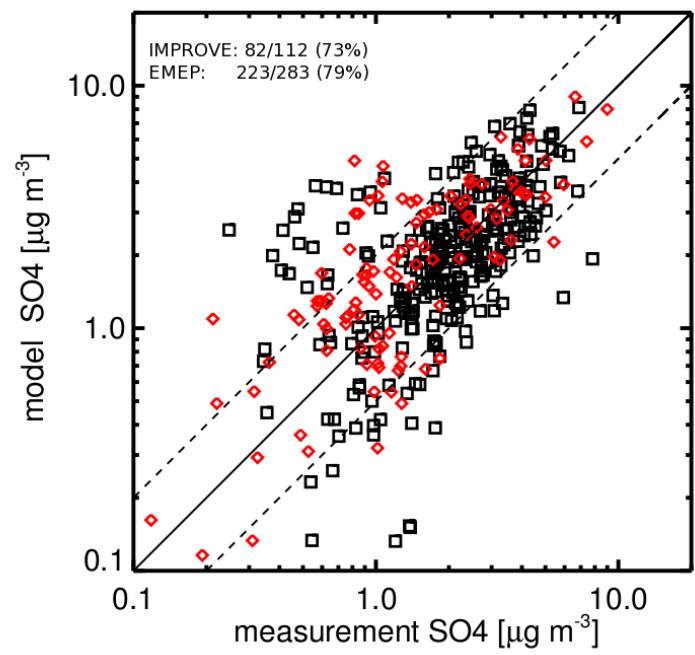

(b)

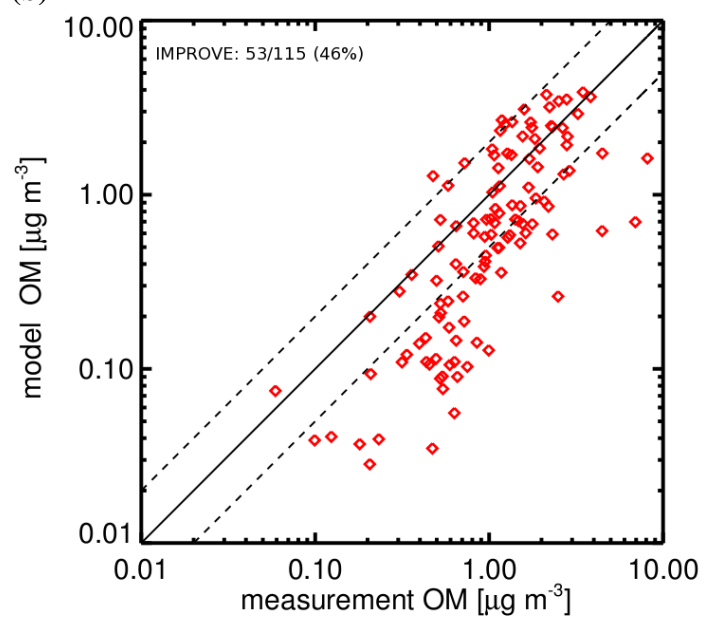

(c)

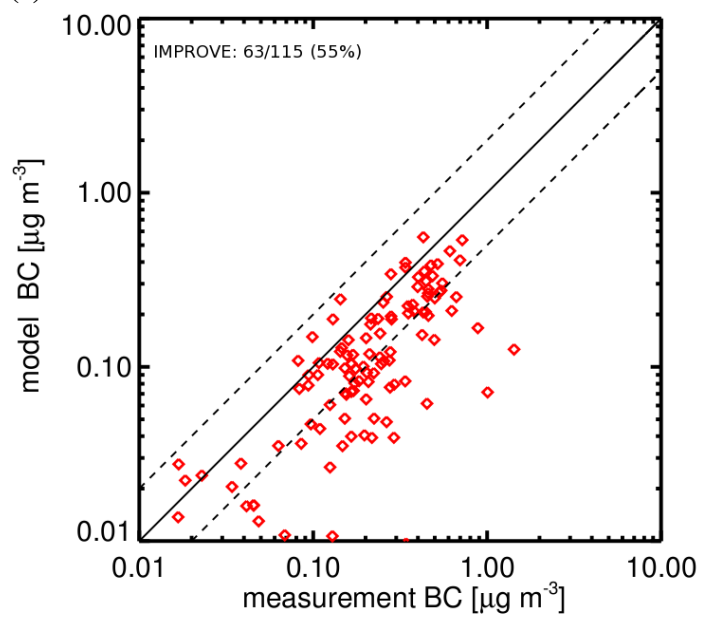

(d)

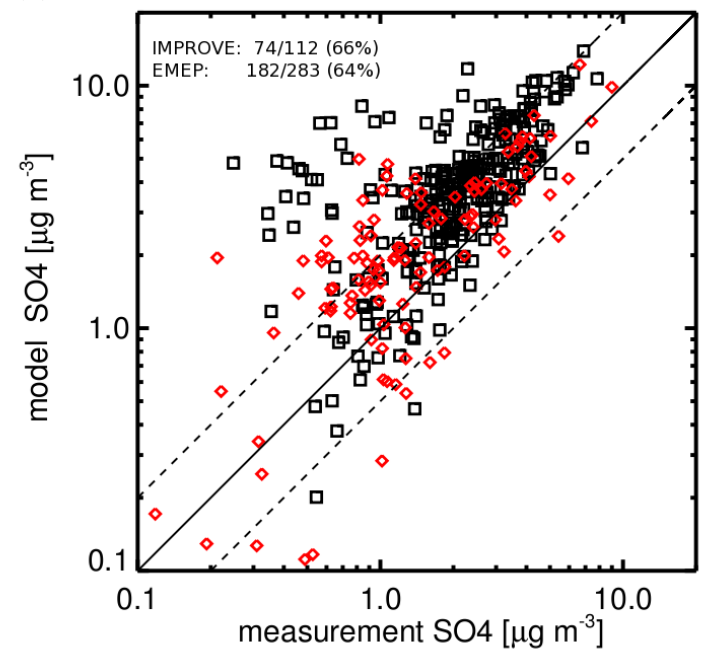

(e)

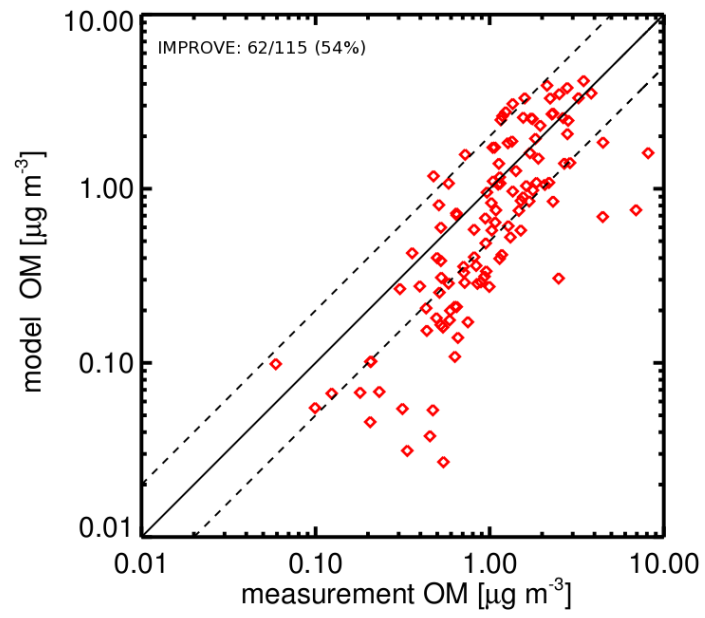

(f)

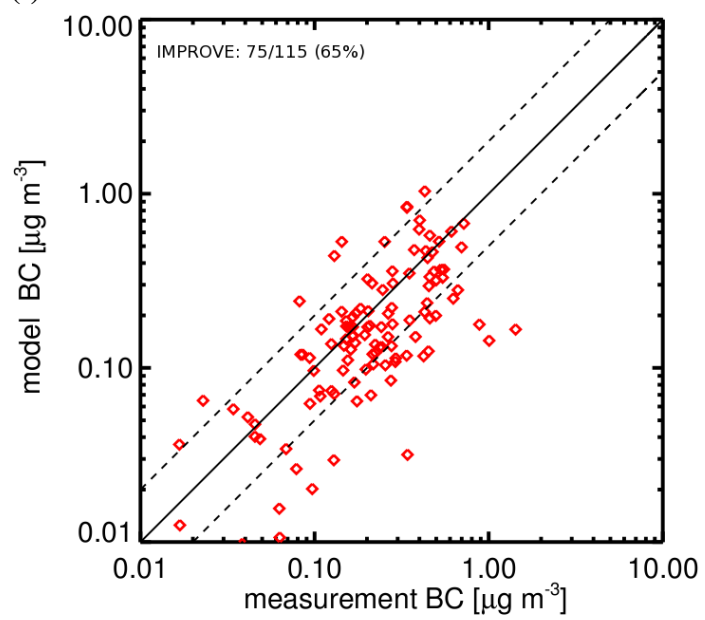

Fig. A1. Simulated versus measured monthly mean aerosol surface concentrations of SO4, BC and POM. Units of sulfate are $\left[\mu \mathrm{g}\left(\mathrm{SO}_{4}\right) / \mathrm{m}^{-3}\right]$ and for BC and POM $\left[\mu \mathrm{g} / \mathrm{m}^{-3}\right]$. (a)-(c) this study. (d)-(f) ECHAM5-HAM reference simulation as given in Stier et al. (2005). Measurements of the EMEP network are shown in black, for the IMPROVE network in red. The solid line indicates the 1:1 ratio, the dashed lines the 2:1 and 1:2 ratios. Values in the figure represent: the number of samples that agree within a factor of two difference with the measurements/total number of samples (\% of samples that agree withing a factor of two difference). 
(a) Emission Sulfur
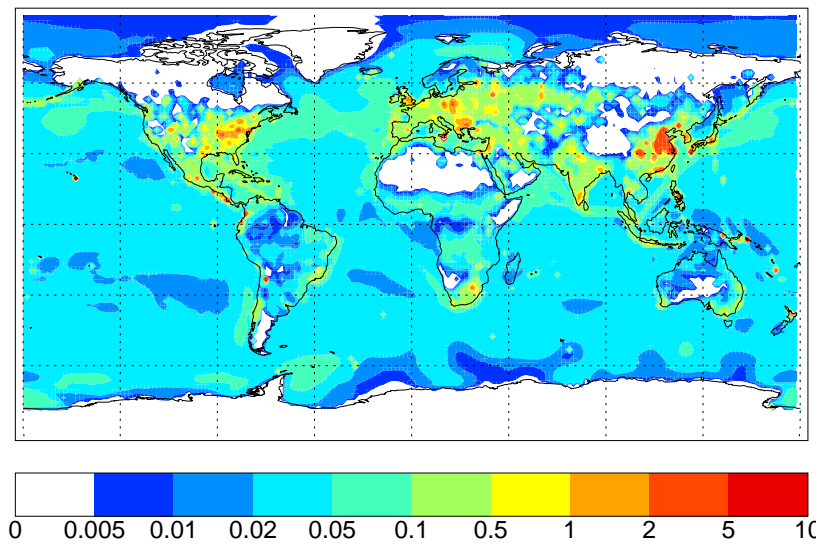

(b) Emission BC
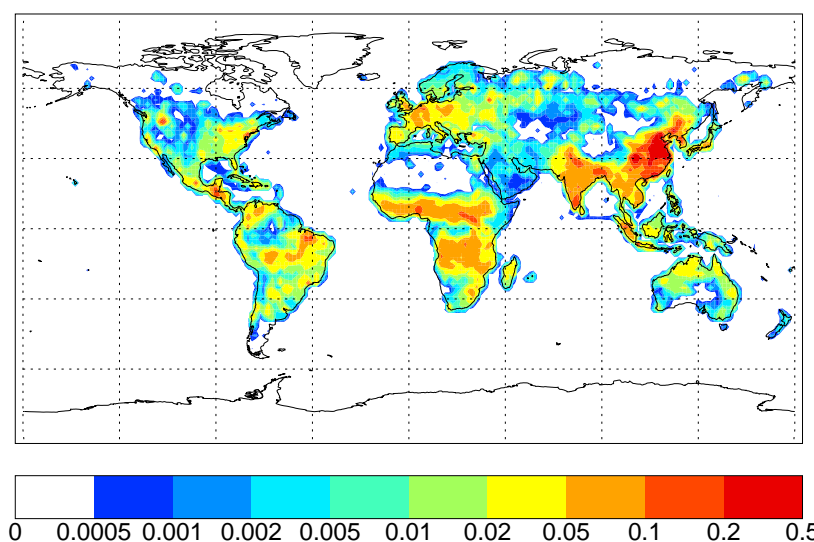

\section{(c) Emission POM}
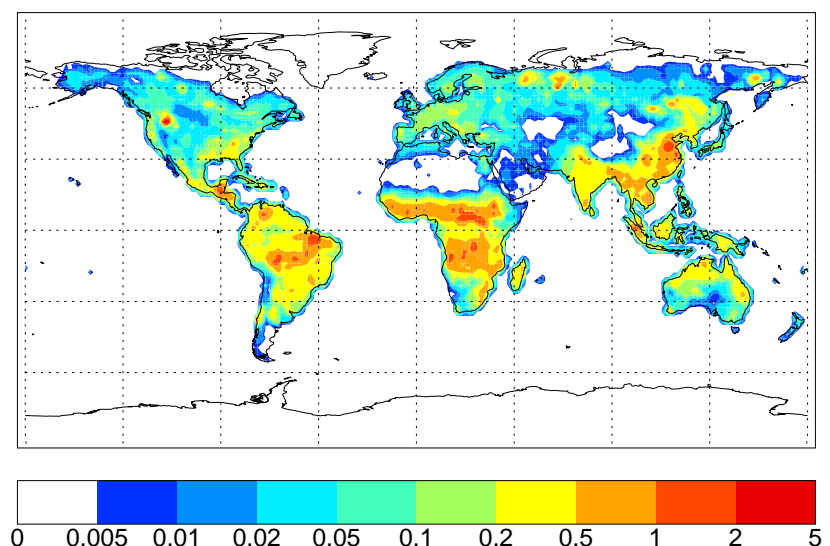

(d) Burden $\mathrm{SO}_{4}$
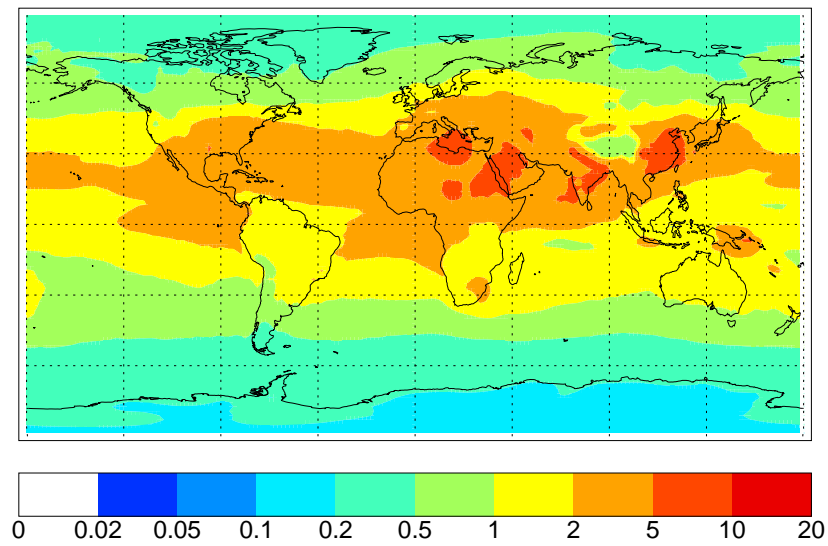

(e) Burden BC
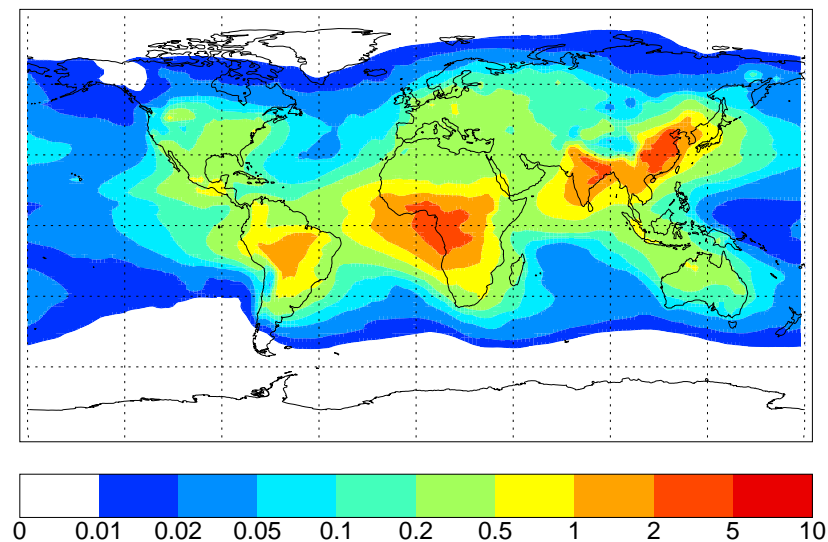

\section{(f) Burden POM}
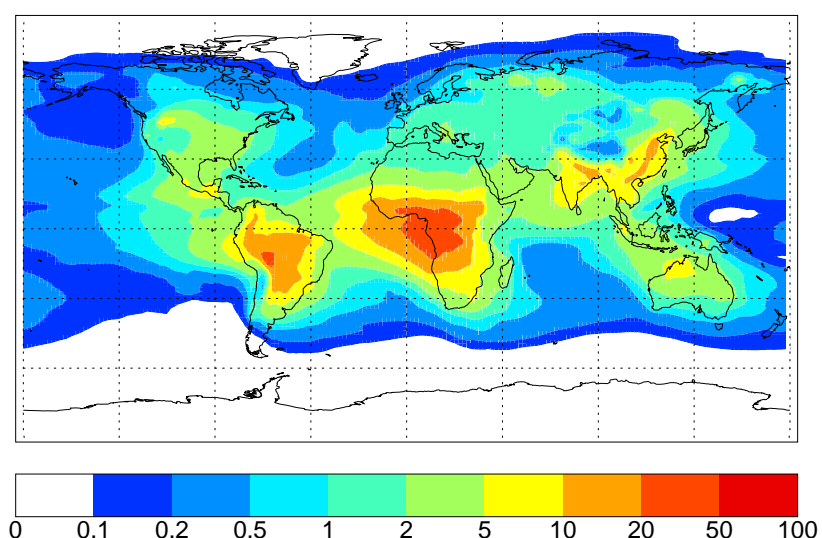

Fig. A2. Annual mean total aerosol and aerosol precursor emission $\left[\mathrm{mg} /\left(\mathrm{m}^{2} * \mathrm{~s}\right)\right]$ and aerosol burdens $\left[\mathrm{mg} /\left(\mathrm{m}^{2}\right)\right]$ for the year $2000 \mathrm{experiment}$ (2000). Units for sulfur emissions and sulfur burden $\operatorname{are}\left[\mathrm{mg}(\mathrm{S}) /\left(\mathrm{m}^{2} * \mathrm{~s}\right)\right]$ and $\left[\mathrm{mg}(\mathrm{S}) /\left(\mathrm{m}^{2}\right)\right]$, respectively. 
(a) PI
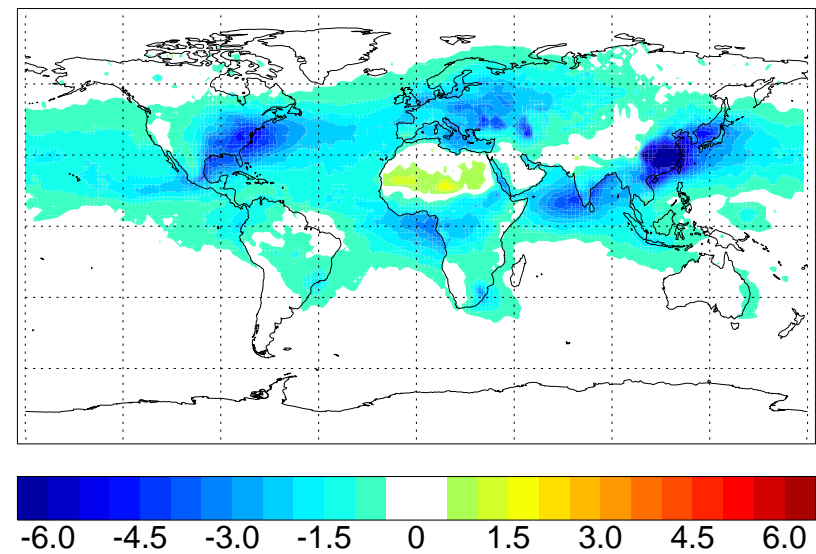

(b) CLE:2030
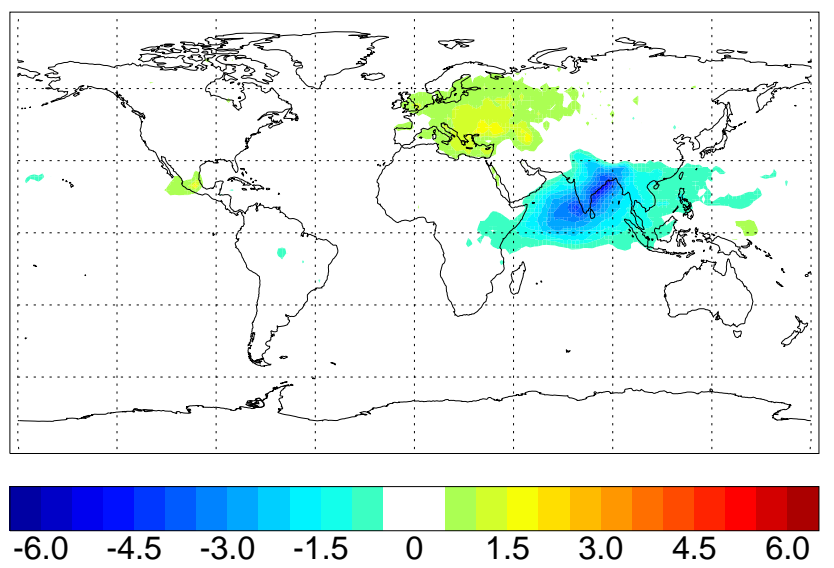

(c) MFR:2030:DT
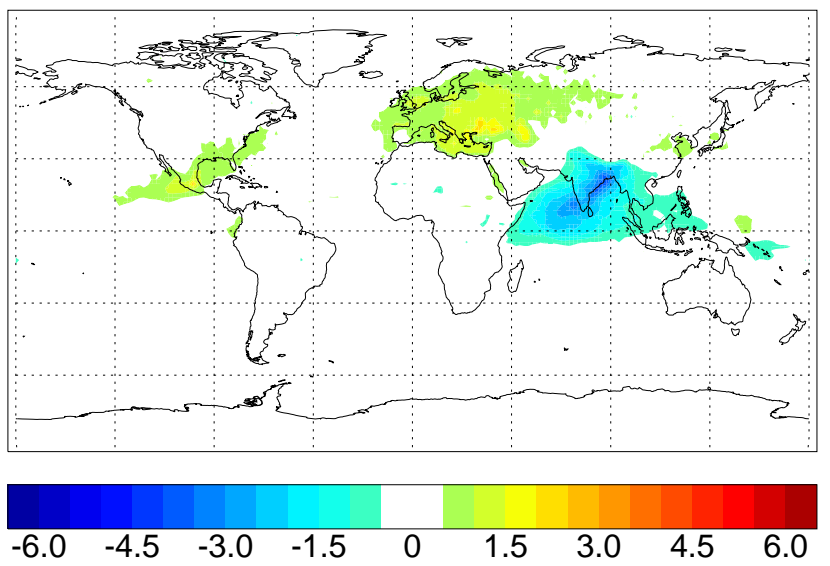

(d) MFR:2030
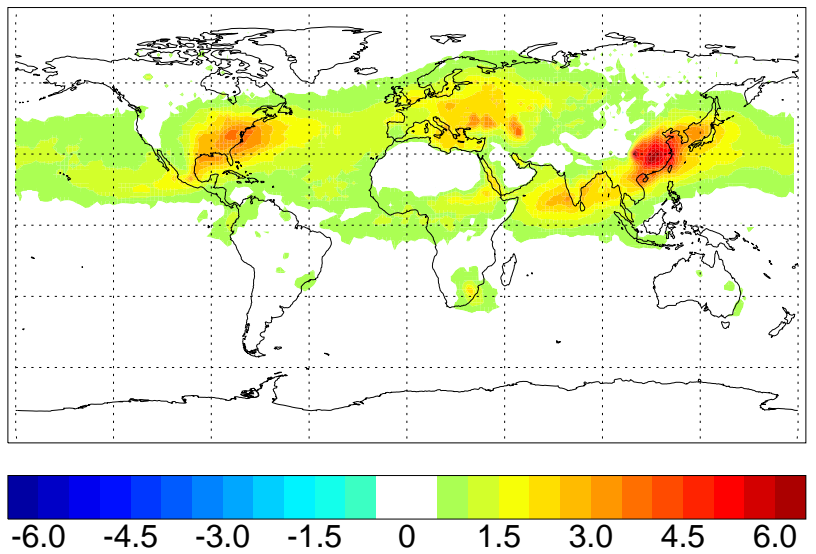

(e) MFR:2030:IP
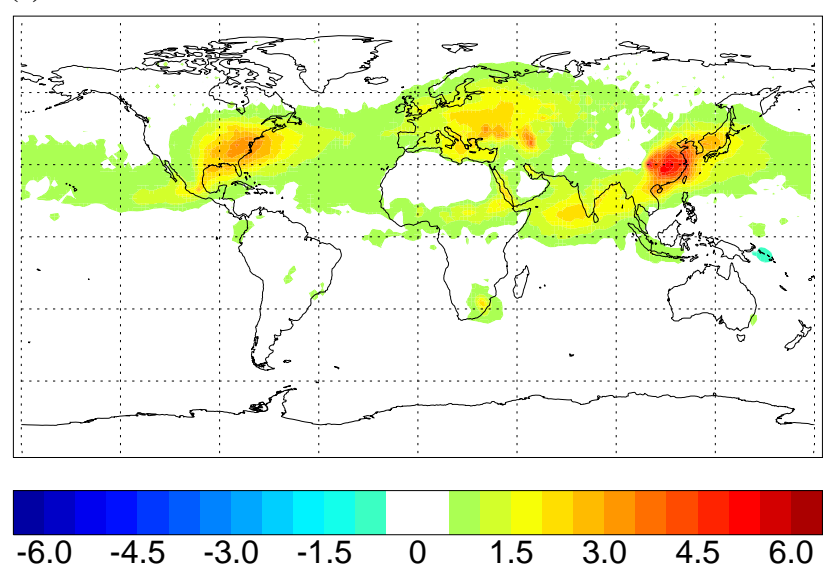

Fig. A3. Annual mean clear-sky radiative forcing $(\mathrm{RF})$ at the top of the atmosphere (TOA) for the baseline scenarios in $\left[\mathrm{W} / \mathrm{m}^{2}\right]$. 


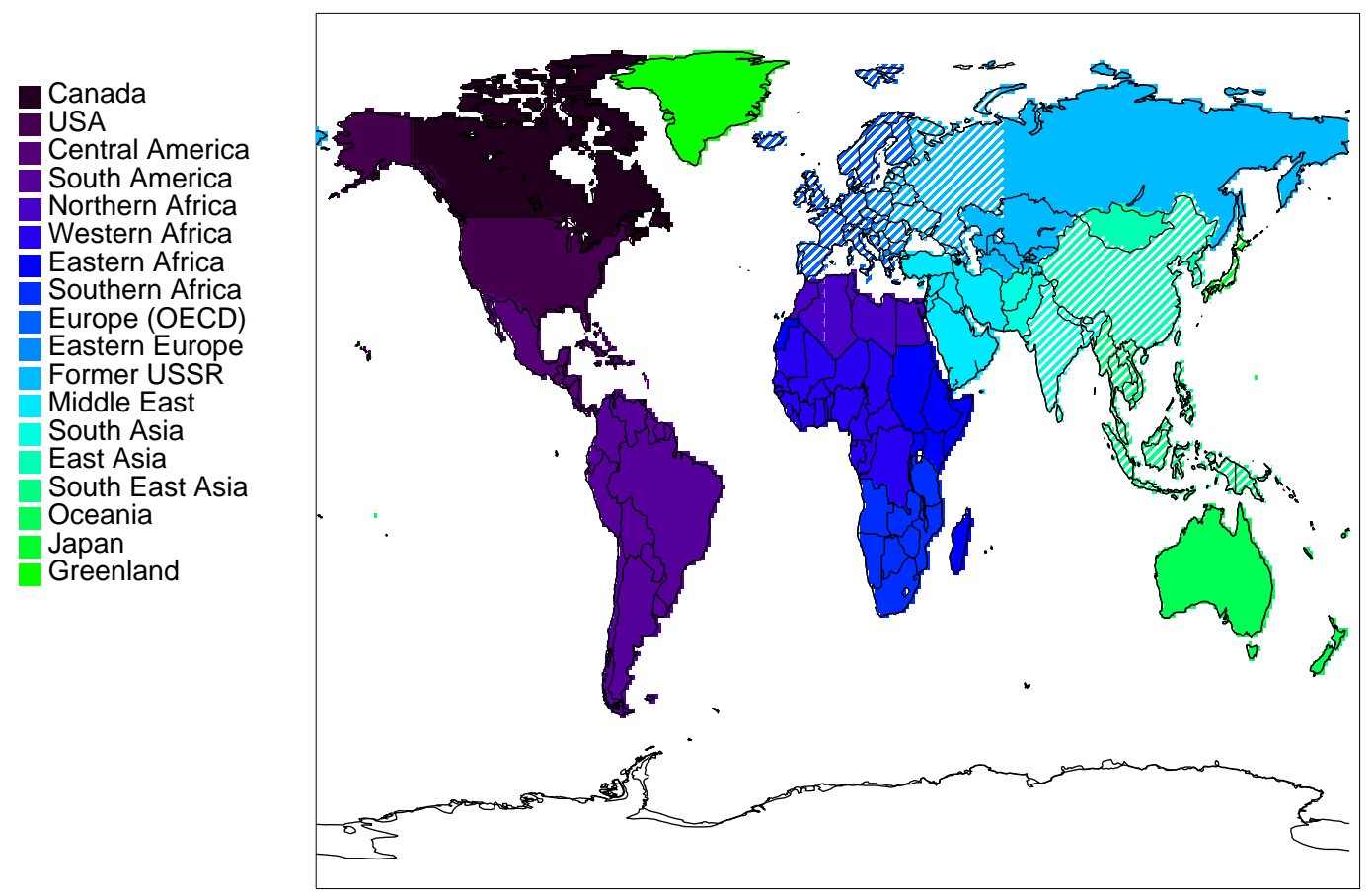

Fig. A4. Region definition following the IMAGE project (http://www.rivm.nl/image/background_info/regions/). Gray shaded regions represent the regions used for the regional experiments MFR:2030:EUROPE and MFR:2030:ASIA.

Acknowledgements. The authors thank Z. Klimont for the emission data and the German Computing Centre (DKRZ), the Swiss Computing Centre (CSCS) and the ECMWF for computing time. This work was partly supported by NSF-0758369.

Edited by: P. Monks

\section{References}

Albrecht, B. A.: Aerosols, cloud microphysics, and fractional cloudiness, Science, 245, 1227-1230, 1989.

Andreae, M.: Atmospheric aerosols versus greenhouse gases in the twenty first century, Philos. T. R. Soc. A, 365, 1915-1923, doi:10.1098/rsta.2007.2051, 2007.

Ångstroem, A.: Atmospheric turbitidy, global illumination and planetary albedo of the earth, Tellus, 14, 435-450, 1962.

Barth, M. C., Rasch, P. J., Kiehl, J. T., Benkovitz,C. M., and Schwartz, S. E.: Sulfur chemistry in the National Center for Atmospheric Research Community Climate Model: Description, evaluation, features, and sensitivity to aqueous chemistry, J. Geophys. Res., 105, 1387-1415, 2000.

Bond, T. C., Streets, D. G., Yarber, K. F., Nelson, S. M., Woo, J. H., and Klimont, Z.: A technology-based global inventory of black and organic carbon emissions from combustion, J. Geophys. Res., 109, D14203, doi:10.1029/2003JD003697, 2004.

Brasseur, G. P. and Roeckner, E.: Impact of improved air quality on the future evolution of climate, Geophys. Res. Lett., 32, L23704, doi:10.1029/2005GL023902, 2005.

Cagnazzo, C., Manzini, E., Giorgetta, M. A., Forster, P. M. D. F., and Morcrette, J. J.: Impact of an improved shortwave radiation scheme in the MAECHAM5 general circulation model, Atmos. Chem. Phys., 7, 2503-2515, 2007, http://www.atmos-chem-phys.net/7/2503/2007/.

Cofala, J., Amann, M., Klimont, Z., Kupiainen, K., and HöglundIsaksson, L.: Scenarios of global anthropogenic emissions of air pollutants and methane until 2030, Atmos. Environ., 41(38), 8486-8499, doi:10.1016/j.atmosenv.2007.07.010, 2007.

Denman, K. L., Brasseur, G., Chidthaisong, A., Ciais, P., Cox, P. M., Dickinson, R. E., Hauglustaine, D., Heinze, C., Holland, E., Jacob, D., Lohmann, U., Ramachandran, S., da Silva Dias, P. L., Wofsy, S. C., and Zhang, X.: Couplings between changes in the climate system and biogeochemistry, in :Climate Change 2007: The Physical Science Basis. Contribution of working group I to the fourth Assessment Report on the Intergovernmental Panel on Climate Change, edited by: Solomon, S., Wuin, D., Manning, M., Chen, Z., Marquis, M., Averyt, K., Tignor, M., and Miller, H., Cambridge University Press, Cambrige, United Kingdom and New York, NY, USA, 2007.

Dentener, F., Peters, W., Krol, M., Weele, M. V., Bergamaschi, P., and Lelieveld, J.: Inter-annual-variability and trend of $\mathrm{CH}_{4}$ lifetime as a measure for $\mathrm{OH}$ changes in the 1979-1993 time period, J. Geophys. Res., 108(D5), 4442, doi:10.1029/2002JD002916, 2003.

Dentener, F., Stevenson, D., Cofala, J., Mechler, R., Amann, M, Bergamaschi, P., Raes, F., and Derwent, R: The impact of air pollutant and methane emissions controls on tropospheric ozone and radiative forcing: CTM calculations for the period 19902030, Atmos. Chem. Phys., 5, 1731-1755, 2005, http://www.atmos-chem-phys.net/5/1731/2005/.

Dentener, F., Kinne, S., Bond, T., Boucher, O., Cofala, J., Generoso, 
S., Ginoux, P., Gong, S., Hoelzemann, J. J., Ito, A., Marelli, L., Penner, J. E., Putaud, J.-P., Textor, C., Schulz, M., van der Werf, G. R., and Wilson, J.: Emissions of primary aerosol and precursor gases in the years 2000 and 1750 prescribed data-sets for AeroCom, Atmos. Chem. Phys., 6, 4321-4344, 2006 a.

Dentener, F., Stevenson, D., Ellingsen, K., Noije, T. V., Schultz, M., Amann, M., Atherton, C., Bell, N., Bergmann, D., Bey, I., Bouwman, L., Butler, T., Cofala, J., Collins, B., Drevet, J., Doherty, R., Eickhout, B., Eskes, H., Fiore, A., Gauss, M., Hauglustaine, D., Horowitz, L., Isaksen, I., Josse, B., Lawrence, M., Krol, M., Lamarque, J., Montanaro, V., Mueller, J., Peuch, V., Pitari, G., Pyle, J., Rast, S., Rodriguez, J., Sanderson, M., Savage, N., Shindell, D., Strahan, S., Szopa, S., Sudo, K., Dingenen, R. V., Wild, O., and Zeng, G.: The Global Atmospheric Environment for the Next Generation, Environ. Sci. Technol., 40, 3586-3594, $2006 \mathrm{~b}$.

EPA: National Air Pollutant Emission Trends, 1900-1998, U.S. Environmental Protection Agency, Office of Air Quality Planning and Standards, http://www.epa.gov/ttn/chief/trends/ trends98/trends98.pdf, 2000.

Eyring, V., Koehler, H., Lauer, A., and Lemper, B.: Emissions from international shipping: 2 . Impact of future technologies on scenarios until 2050, J. Geophys. Res., 110, D17306, doi:10.1029/2004JD005620, 2005.

Feichter, J., Kjellstrom, E., Rodhe, H., Dentener, F., Lelieveld, J., and Roelofs, G.-F.: Simulation of the tropospheric sulfur cycle in a global climate model, Atmos. Environ., 30(10-11), 16931707, 1996.

Feichter, J., Roeckner, E., Lohmann, U., and Liepert, B.: Nonlinear aspects of the climate response to greenhouse gas and aerosol forcing, J. Climate, 17(12), 2384-2398, 2004.

Forster, P., Ramawamy, V., Artaxo, P., Berntsen, T., Betts, R., Fahey, D., Haywood, J., Lean, J., Lowe, D., Myhre, G., Nganga, J., Prinn, R., Raga, G., Schulz, M., and Dorland, R. V.: Changes in Atmospheric Constituents and in Radiative Forcing, in: Climate Change 2007: The Physical Science Basis. Contribution of working group I to the fourth Assessment Report on the Intergovernmental Panel on Climate Change, edited by: Solomon, S., Wuin, D., Manning, M., Chen, Z., Marquis, M., Averyt, K., Tignor, M., and Miller, H., Cambridge University Press, Cambrige, United Kingdom and New York, NY, USA, 2007.

Graf, H.-F., Feichter, J., and Langmann, B.: Volcanic sulfur emissions: Estimates of source strength and its contribution to the global sulfate distribution, J. Geophys. Res., 102, 10727-10 738, 1997.

Hansen, J., Sato, M., and Ruedy, R.: Radiative forcing and climate response, J. Geophys. Res., 102, 6831-6864, 1997.

Horowitz, L. W., Walters, S., Mauzerall, D. L., Emmons, L. K., Rasch, P. J., Granier, C., Tie, X. X., Lamarque, J. F., Schultz, M. G., Tyndall, G. S., Orlando, J. J., and Brasseur, G. P.: A global simulation of tropospheric ozone and related tracers: Description and evaluation of MOZART, Version 2, J. Geophys. Res., 108(D24), 4784, doi:10.1029/2002JD002853, 2003.

IPCC, Climate change 2001: The scientific basis, Cambridge University Press, J. T. Houghton, 881 pp., 2001.

Jeuken, A., Siegmund, P., Heijboer, L., Feichter, J., and Bengtsson, L.: On the potential of assimilating meteorological analyses in a global climate model for the purpose of model validation, J. Geophys. Res., 101, 16939-16 950, doi:10.1029/96JD01218, 1996.
Kettle, A. J. and Andreae, M. O.: Flux of dimethylsulfide from the oceans: A comparison of updated data sets and flux models, J. Geophys. Res., 105(D22), 26 793-26808, 2000.

Khairoutdinov, M. and Kogan, Y.: A new cloud physics parameterization in a large-eddy simulation model of marine stratocumulus, Mon. Weather Rev., 128(1), 229-243, 2000.

Kloster, S., Six, K., Feichter, j., Maier-Reimer, E., Roeckner, E., Wetzel, P., Stier, P., and Esch, M.: Response of dimethylsulfide (DMS) in the ocean and atmosphere to global warming, J. Geophys. Res., 112, G03005, doi:10.1029/2006JG000224, 2007.

Koch, D., Bond, T., Streets, D., Unger, N., and van der Werf, G.: Global impacts of aerosols from particular source regions and sectors, J. Geophys. Res., 112, D02205, doi:10.1029/2005JD007024, 2007.

Koch, D., Bond, T., Streets, D., and Unger, N: Linking future aerosol radiative forcing to shifts in source activities, Geophys. Res. Lett., 34, doi:10.1029/2006GL028360, 2007 b.

Lin, H. and Leaitch, R.: Development of an in-cloud aerosol activation parameterization for climate modelling, in: WMO workshop on measurements of cloud properties for forcast of weather, edited by: W. M. Organization, 328-335, Geneva, 1997.

Lin, S. J. and Rood, R. B.: Multidimensional flux-form semilagrangian transport schemes, Mon. Weather Rev., 124(9), 20462070, 1996.

Lohmann, U. and Feichter, J.: Impact of sulfate aerosols on albedo and lifetime of clouds: A sensitivity study with the ECHAM4 GCM, J. Geophys. Res., 102(D12), 13 685-13 700, 1997.

Lohmann, U., Feichter, J., Chuang, C. C., and Penner, J. E.: Prediction of the number of cloud droplets in the ECHAM GCM, J. Geophys. Res., 104(D20), 24 557-24 563, 1999.

Lohmann, U., Stier, P., Hoose, C., Ferrachat, S., Kloster, S., Roeckner, E., and Zhang, J.: Cloud microphysics and aerosol indirect effects in the global climate model ECHAM5-HAM, Atmos. Chem. Phys., 7, 3425-3446, 2007,

http://www.atmos-chem-phys.net/7/3425/2007/.

Mahowald, N., Lamarque, J.-F., Tie, X., and Wolff, E.: Sea salt aerosol response to climate change: last glacial maximum, preindustrial and doubled carbon dioxide climates, J. Geophys. Res., 111, D05303, doi:10.1029/2005JD006,459, 2006a.

Mahowald, N., Muhs, D., Levis, S., Rasch, P., Yoshioka, M., Zender, C., and Luo, C.: Change in atmospheric mineral aerosols in response to climate: Last glacial period, preindustrial, modern, and doubled carbon dioxide climates, J. Geophys. Res., 111, D10202, doi:10.1029/2005JD006653, 2006b.

Menon, S., Unger, N., Koch, D., Francis, J., Garret, T., Sednev, I., Shindell, D., and Street, D.: Aerosol climate effects and air quality impacts from 1980 to 2030, Environ. Res. Lett., 3, 024004 , doi:10.1088/1748-9326/3/2/024004, 2008.

Morcrette, J. J., Clough, S. A., Mlawer, E. J., and Iacono, M. J.: Impact of a validated radiative transfer scheme, RRTM, on the ECMWF model climate and 10-day forecasts, Technical Memorandum 252, ECMWF, Reading, UK, 1998.

Nakicenovic, N., Alcamo, J., Davis, G., de Vries, B., Fenhann, J., Gaffin, S., Gregory, K., Gruebler, A., Jung, T., Kram, T., Rovere, E. L., Michaelis, L., Mori, S., Morita, T., Pepper, W., Pitcher, H., Price, L., Riahi, K., Roehrl, A., Rogner, H.-H., Sankovski, A., Schlesinger, M., Shukla, P., Smith, S., Swart, R., van Rooijen, S., Victor, N., and Dadi, Z.: Special Report on Emissions Scenarios, in: Contribution to the Intergovernmental Panel on 
Climate Change, Cambridge University Press, Cambridge, UK, 2000 .

Nightingale, P. D., Malin, G., Law, C. S., Watson, A. J., Liss, P. S., Liddicoat, M. J., Boutin, J., and Upstill-Goddard, R. C.: In situ evaluation of air-sea gas exchange parameterizations using novel conservative and volatile tracers, Global Biogeochem. Cy., 14(1), 373-387, 2000.

Nordeng, T. E.: Extended versions of the convective parameterization scheme at ECMWF and their impact on the mean and transient activity of the model in the tropics, Technical Memorandum 206, ECMWF, Reading, UK, 1994.

Olivier, J. and Berdowski, J.: Global emission sources and sinks, chap. The Climate System, Swets and Zeitlinger Publishers, Lisse, The Netherlands, 2001.

Olivier, J., Berdowski, J., Peters, J., Bakker, J., Visschedijk, A., and Bloos, J.: Applications of edgar including a description of edgar v3.0: reference database with trend data for 1970-1995, NRP report 410200 051, RIVM, Bilthoven, The Netherlands, 2002.

Pham, M., Boucher, O., and Hauglustaine, D.: Changes in atmospheric sulfur burdens and concentrations and resulting radiative forcings under IPCC SRES emission scenarios for 1990-2100, J. Geophys. Res., 110, D06112, doi:10.1029/2004JD005125, 2005.

Pozzoli, L., Bey, I., Rast, J., Schultz, M., Stier, P., and Feichter, J.: Trace gas and aerosol interactions in the fully coupled model of aerosol-chemistry-climate ECHAM5-HAMMOZ, PART1: Model descripstion and insights from the spring 2001 TRACE-P experiment, J. Geophys. Res., 113, D07308, doi:10.1029/2007JD009007, 2007.

Reddy, M., Boucher, O., and Balkanski Y.: Aerosol optical depths and direct radiative perturbations by species and source type, Geophys. Res. Lett., 32(12), L12803, doi:10.1029/2004GL021743, 2005.

Riahi, K. and Roehl, R.: Greenhouse Gas Emissions in Dynamisas-Usual Scenario of Economic and Energy Development, Technical Forcasting and Social Change 63, 175-205, North Holland, 2005.

Roeckner, E., Baeuml, G., Bonventura, L., Brokopf, R., Esch, M., Giorgetta, M., Hagemann, S., Kirchner, I., Kornblueh, L., Manizini, E., Rhodin, A., Schlese, U., Schulzweida, U., and Tompkins, A.: The atmospheric general circulation model ECHAM5, Part I: Model description, Report 349, Max Planck Institute for Meteorology, Hamburg, Germany, http://www.mpimet.mpg.de, 2003.

Roelofs, G.-J., Lelieveld, J., and Ganzeveld, L.: Simulation of global sulfate distribution and the influence on effective cloud drop radii with a coupled photochemistry sulfur cycle model, Tellus B, 50(3), 224-242, 1998.

Schulz, M., de Leeuw, G., and Balkanski, Y.: Sea salt aerosol source functions and emissions, in: Emission of atmospheric trace compounds, edited by: Granier, C., Artaxo, P., and Reeves, C., Ed. Kluwer, 333-359, 2004.

Shindell, D. T, Faluvegi, G., Bauers, S. E., Koch, D., Unger, N., Menon, S., Miller, R. L., Schmidt, G. A., and Streets, D.: Climate response to projected changes in short-lived species under an A1B scenario from 2000-2050 in the GISS climate model, J. Geophys. Res., 112, D20103, doi:10.1029/2007JD008753, 2007.

Shindell, D. T., Levy, H., Schwarzkopf, M. D., Horrowitz, L. W., Lamarque, J. F., and Faluvegi, G.: Multimodel projections of climate change from short-lived emissions due to human activities,
J. Geophys. Res., 113, D11109, doi:10.1029/2007JD009152, 2008.

Stier, P., Feichter, J., Kinne, S., Kloster, S., Vignati, E., Wilson, J., Ganzeveld, L., Tegen, I., Werner, M., Balkanski, Y., Schulz, M., Boucher, O., Minikin, A., and Petzold, A.: The aerosolclimate model ECHAM5-HAM, Atmos. Chem. Phys., 5, 11251156, 2005, http://www.atmos-chem-phys.net/5/1125/2005/.

Stier, P., Feichter, J., Kloster, S., Vignati, E., and Wilson, J.: Emission-induced nonlinearities in the global aerosol system results from the ECHAM5-HAM aerosol-climate model, J. Climate, 19(16), 3845-3861, 2006a.

Stier, P., Seinfeld, J., Kinne, S., Feichter, J., and Boucher, O.: Impact of non-absorbing anthropogenic aerosols on clearsky atmospheric absorption, J. Geophys. Res., 111, D18201, doi:10.1029/2006JD007147, 2006b.

Stier, P., Feichter, J., Roeckner, E., Kloster, S., and Esch, M.: The evolution of the global aerosol system in a transient climate simulation from 1860 to 2100, Atmos. Chem. Phys., 6, 2389-2399, 2006 c.

Streets, D., Bond, T., Lee, T., and Jang, C.: On the future of carbonaceous aerosol emissions, J. Geophys. Res., 109, D24212, doi:10.1029/2004JD004902, 2004.

Sundquist, H., Berge, E., and Kristiansson, J. E.: Condensation and cloud parameterization studies with a mesoscale numerical weather prediction model, Mon. Weather Rev., 117, 1657-1614, 1989.

Takemura, T., Nakajima, T., Dubovik, O., Holben, B. N., and Kinne, S.: Single-scattering albedo and radiative forcing of various aerosol species with a global three-dimensional model, J. Climate, 15, 333-352, 2002.

Tegen, I., Harrison, S. P., Kohfeld, K., Prentice, I. C., Coe, M., and Heimann, M.: Impact of vegetation and preferential source areas on global dust aerosol: Results from a model study, J. Geophys. Res., 107(D21), 4576, doi:10.1029/2001JD000963, 2002.

Tegen, I., Werner, M., Harrison, S. P., and Kohfeld, K. E.: Relative importance of climate and land use in determining present and future global soil dust emission, Geophys. Res. Lett., 31(5), L05105, doi:10.1029/2003GL019216, 2004.

Tiedtke, M.: A comprehensive mass flux scheme for cumulus parameterization in large-scale models, Mon. Weather Rev., 117(8), 1779-1800, 1989.

Twomey, S.: The influence of pollution on the shortwave albedo of clouds, J. Atmos. Sci., 34, 1249-1152, 1977.

Unger, N., Shindell, D., Koch, D., and Streets, D.: Cross influence of ozone and sulfate precursor emission changes on air quality and climate, P. Natl. Acad. Sci. USA, 97, 9875-9880, 2006.

Unger, N., Shindell, D., Koch, D., and Streets, D.: Air pollution radiative forcing from specific emissions sectors at 2030, J. Geophys. Res., 113, D02306, doi:10.1029/10.1029/2007JD008683, 2008.

Uppala, S. M., Kallberg, P. W., Simmons, A. J., Andrae, U., Da Costa Bechtold, V., Fiorino, M., Gibson, J. K., Haseler, J., Hernandez, A., Kelly, G. A., Li, X., Onogi, K., Saarinen, S., Sokka, N., Allan, R. P., Andersson, E., Arpe, K., Balmaseda, M. A., Beljaars, A. C. M., Van De Berg, L., Bidlot, J., Bormann, N., Caires, S., Chevallier, F., Dethof, A., Dragosavac, M., Fisher, M., Fuentes, M., Hagemann, S., Holm, E., Hoskins, B. J., Isaksen, L., Janssen, P. A. E. M., Jenne, R., Mcnally, A. P., Mahfouf, 
J.-F., Morcrette, J.-J., Rayner, N. A., Saunders, R. W., Simon, P., Sterl, A., Trenberth, K. E., Untch, A., Vasiljevic, D., Viterbo, P., and Woollen, J.: The ERA-40 re-analysis, Q. J. Roy. Meteor. Soc., 131, 2961-3012, 2005.

Vestreng, V., Myhre, G., Fagerlil, H., Reis, S., and Tarrasón, L.: Twenty-five years of continuous sulphur dioxide emission reduction in europe, Atmos. Chem. Phys., 7, 3663-3681, 2007, http://www.atmos-chem-phys.net/7/3663/2007/.
Vignati, E., Wilson, J., and Stier, P.: An efficient sizeresolved aerosol microphysics module for large-scale aerosol transport models, J. Geophys. Res., 109(D22), D22202, doi:10.1029/2003JD004485, 2004.

WHO: Health Aspects of Air Pollution with Particulate Matter, Ozone and Nitrogen Dioxide, Report on a WHO Working group, Bonn, Germany, www.euro.who.int/document/e79097. pdf, 2003. 